\title{
Towards a natural classification of annulatascaceae-like taxa II: introducing five new genera and eighteen new species from freshwater
}

\author{
Dong $\mathrm{W}^{1,2,3,4,5}$, Hyde $\mathrm{KD}^{4,5,6,7}$, Jeewon $\mathrm{R}^{8}$, Doilom $\mathrm{M}^{5,7,9,10}$, Yu XD ${ }^{1,11}$, Wang $\mathrm{GN}^{12}$, \\ Liu NG ${ }^{4}$, Hu DM ${ }^{13}$, Nalumpang $\mathrm{S}^{2,3}$, Zhang $\mathrm{H}^{1,14,15^{*}}$
}

\begin{abstract}
${ }^{I}$ Faculty of Agriculture and Food, Kunming University of Science \& Technology, Kunming 650500, China
${ }^{2}$ Department of Entomology and Plant Pathology, Faculty of Agriculture, Chiang Mai University, Chiang Mai 50200, Thailand

${ }^{3}$ Innovative Agriculture Research Center, Faculty of Agriculture, Chiang Mai University, Chiang Mai 50200, Thailand ${ }^{4}$ Center of Excellence for Fungal Research, Mae Fah Luang University, Chiang Rai 57100, Thailand

${ }^{5}$ Innovative Institute for Plant Health, Zhongkai University of Agriculture and Engineering, Haizhu District, Guangzhou 510225, China

${ }^{6}$ Mushroom Research Foundation, 128 M.3 Ban Pa Deng T. Pa Pae, A. Mae Taeng, Chiang Mai 50150, Thailand

${ }^{7}$ Research Center of Microbial Diversity and Sustainable Utilization, Faculty of Sciences, Chiang Mai University, Chiang Mai 50200, Thailand

${ }^{8}$ Department of Health Sciences, Faculty of Medicine and Health Sciences, University of Mauritius, Reduit, Mauritius

${ }^{9} \mathrm{CAS}$, Key Laboratory for Plant Diversity and Biogeography of East Asia, Kunming Institute of Botany, Chinese Academy of Sciences, Kunming 650201, China

${ }^{10}$ Department of Biology, Faculty of Science, Chiang Mai University, Chiang Mai 50200, Thailand

${ }^{11}$ School of Life Science and Technology, University of Electronic Science and Technology of China, Chengdu 611731, China

${ }^{12}$ Faculty of Environmental Science and Engineering, Kunming University of Science \& Technology, Kunming 650500, China

${ }^{13}$ Bioengineering and Technological Research Centre for Edible and Medicinal Fungi, Jiangxi Agricultural University, Nanchang 330045, China

${ }^{14}$ Department of Botany, University of British Columbia, Vancouver V6T, Canada

${ }^{15}$ Yunnan Key Lab of Soil Carbon Sequestration and Pollution Control, Kunming University of Science and Technology, Kunming 650500, China
\end{abstract}

Dong W, Hyde KD, Jeewon R, Doilom M, Yu XD, Wang GN, Liu NG, Hu DM, Nalumpang S, Zhang H 2021 - Towards a natural classification of annulatascaceae-like taxa II: introducing five new genera and eighteen new species from freshwater. Mycosphere 12(1), 1-88, Doi 10.5943/mycosphere/12/1/1

\begin{abstract}
Annulatascaceae is an interesting and taxonomically confused family as some family members have been placed in different orders/families in Diaporthomycetidae. Although taxonomic changes have been carried out for some genera, many are questionable or their placements are unstable due to a lack of DNA sequence data. In this study, a survey of freshwater annulatascaceaelike species resulted in 23 new taxa, including five new genera (Aquidictyomyces, Fusoidigranularius, Longivarius, Neodiluviicola and Obliquiminima) and 18 new species in 12 genera, i.e. Annulatascus (A. chiangmaiensis, A. nakhonensis and A. songkhlaensis), Aquapteridospora (A. aquatica), Aquidictyomyces (A. appendiculatus), Cancellidium ( $C$. thailandense), Conlarium (C. subglobosum), Dictyosporella (D. chiangmaiensis and D. ellipsoidea), Distoseptispora (D. fasciculata, D. saprophytica and D. songkhlaensis), Fluminicola (F. striata), Junewangia (J. thailandica), Obliquiminima (O. hyalina), Sporidesmiella ( $S$. obovoidia) and Sporidesmium (S. appendiculatum and S. chiangmaiense). Annulatascus
\end{abstract}


aquatorbae and A. nilensis are excluded from Annulatascus sensu stricto, and placed in two new genera Longivarius and Fusoidigranularius, respectively. Diluviicola capensis is a new geographical record in Thailand, and D. aquatica is transferred to a new genus Neodiluviicola as $N$. aquatica. Obliquiminima which is morphologically similar to Ayria is introduced as a new sexual genus in Cancellidiaceae. Dictyosporella chiangmaiensis is introduced as the second sexual morph in the genus. Fluminicola thailandensis is synonymized under F. saprophytica and Distoseptispora submersa is synonymized under D. tectonae. Strain HKUCC 3710 under the name Cateractispora recepticuli is rectified as the type strain of Cataractispora receptaculorum. We report a new geographical and habitat record of Acrodictys porosiseptata from freshwater in Thailand; a new geographical record of Conlarium aquaticum in China; and a new geographical record of Diluviicola capensis in Thailand. All taxa are identified based on morphology and phylogenetic analyses of a combined LSU, ITS, TEF and RPB2 DNA sequence data. An updated review for Annulatascaceae, as well as its sexual and asexual allies, is provided under each entry based on our new data.

Key words - 23 new taxa - apical ring - Diaporthomycetidae - submerged wood - taxonomy

\section{Introduction}

Since freshwater fungi was recognized as a distinctive group (Ingold 1942, 1951, 1955), plenty of freshwater species have been discovered (Su et al. 2016, Zhang et al. 2017, Luo et al. 2019, Dong et al. 2020a, b). In the previous studies of freshwater fungi along a north-south latitudinal gradient in the Asian/Australian region (Hyde et al. 2016a), many taxa characterized by small ascomata, with or without long necks, unitunicate, cylindrical asci with an apical ring and fusiform, hyaline ascospores were discovered and morphologically placed in Annulatascaceae (Hyde 1992, Ho et al. 2002, Cai et al. 2003, Luo et al. 2004, Vijaykrishna et al. 2006, Hu et al. 2010). Although phylogenetic analyses have shown that Annulatascaceae members are polyphyletic in nature (Abdel-Wahab et al. 2011, Zelski 2015), they did not revise the taxonomy as DNA sequence data was limited.

A recent study of annulatascaceae-like taxa was carried out by Zhang et al. (2017) based on phylogenetic and evolutionary studies. They established a new order Atractosporales and six new families Atractosporaceae, Barbatosphaeriaceae, Conlariaceae, Lentomitellaceae, Pseudoproboscisporaceae and Woswasiaceae, to accommodate the taxa that morphologically belong in Annulatascaceae. Although the new order and families have been established, a number of them are based on limited data so that some appear to be phylogenetically unstable. For example, some studies showed Atractosporales was not monophyletic, as its three families Atractosporaceae, Conlariaceae and Pseudoproboscisporaceae did not form a well-supported clade and was related to other families (Luo et al. 2019, Hyde et al. 2020); Lentomitellaceae was established for a single genus Lentomitella (Zhang et al. 2017), and later was synonymized under Xenospadicoidaceae that comprises three additional genera (Réblová et al. 2018); Dictyosporella was referred to Diaporthomycetidae genera incertae sedis (Zhang et al. 2017), and now is placed in Junewangiaceae (Luo et al. 2019); Barbatosphaeriaceae and Woswasiaceae were established to accommodate some annulatascaceae-like genera (Zhang et al. 2017), and later some were referred to Diaporthomycetidae genera incertae sedis because of weak phylogenetic relationships between family members (Luo et al. 2019). It clearly demonstrates that the taxonomy of these fungi is unresolved and changes from time to time.

In this study, 30 new freshwater collections are identified as Annulatascaceae and annulatascaceae-like taxa. Annulatascales, along with morphologically similar orders (Atractosporales, Cancellidiales, Conlariales and Sporidesmiales) and families (Junewangiaceae, Papulosaceae and Pseudoproboscisporaceae), as well as Distoseptisporales and Acrodictyaceae which are morphologically similar to Sporidesmiales and Junewangiaceae, are treated. Based on an updated phylogenetic study of Zhang et al. (2017) and our new collections obtained from China and 
Thailand, five new genera and 18 new species are introduced. In addition, three new combinations, three new geographical records and one new freshwater habitat record are presented.

\section{Materials \& Methods}

\section{Specimens collection, examination and single spore isolation}

Decaying wood samples were collected from freshwater streams in China and Thailand. Specimens were placed in zip-lock plastic bags lined with some wetted cotton and taken to the laboratory. The specimens were incubated in moist plastic boxes at room temperature for 1-2 weeks and performed morphological observations. Fruit bodies or colonies were examined using a Nikon SMZ-171 dissecting microscope. Fungal structures were photographed with a Nikon ECLIPSE Ni compound microscope fitted with a Canon EOS 600D/750D digital camera. Single spore isolations were made from ascospores or conidia onto potato dextrose agar (PDA) at room temperature. All details of morphological approaches used herein were based on Chomnunti et al. (2014) and Senanayake et al. (2020). Tarosoft (R) Image Frame Work program was used for measurement. Images used for figures were processed with Adobe Photoshop CS5 software (Adobe Systems, USA). Herbarium specimens (dry wood with fungal material) were deposited in the herbarium of Mae Fah Luang University (MFLU), Chiang Rai, Thailand and herbarium of Cryptogams, Kunming Institute of Botany Academia Sinica (HKAS), Kunming, China. Living cultures were deposited in Mae Fah Luang University Culture Collection (MFLUCC) and Kunming Institute of Botany Culture Collection (KUMCC). Facesoffungi and Index Fungorum numbers were registered as in Jayasiri et al. (2015) and Index Fungorum (2021), respectively.

\section{DNA extraction, PCR amplification and sequencing}

Single germinated spores were grown on PDA for 15-30 days at room temperature to obtain pure cultures. A Biospin Fungus Genomic DNA Extraction Kit (Bioer Technology Co., Hangzhou, China) was used to extract total genomic DNA from fresh mycelia according to the manufacturer's instructions. DNA amplification was performed by polymerase chain reaction (PCR). LSU, SSU, ITS, TEF and RPB2 sequences were amplified using primer pairs LR0R/LR5, NS1/NS4, ITS5/ITS4, 983F/2218R and fRPB2-5F/fRPB2-7cR, respectively (Vilgalys \& Hester 1990, White et al. 1990, Rehner \& Samuels 1994, Liu et al. 1999). The amplifications were carried out as outlined in Dong et al. (2020a). PCR thermal cycles for the amplification followed Su et al. (2015) and Luo et al. (2018). PCR products were checked on 1\% agarose electrophoresis gels stained with Gel Red. The sequencing reactions were carried out by Shanghai Sangon Biological Engineering Technology and Services Co., Shanghai, China.

\section{Phylogenetic analyses}

Raw sequences generated in this study were checked with Finch TV version 1.4.0 and single gene for each strain was blasted in NCBI to confirm the correctness of sequences obtained from company. A multigene phylogenetic tree was constructed based on nucleotide BLAST of each newly generated sequences and recent publications (Zhang et al. 2017, Luo et al. 2019, Hyde et al. 2020). All sequences used in this study are listed in supplementary Table 1. Alignments for each dataset of LSU, ITS, TEF and RPB2 were done using MAFFT v. 7.409 online version (Katoh \& Standley 2016) and manually verified with BioEdit v.7.2.5 Biological Sequence Alignment Editor (Ibis BioSciences, CA). Each dataset were concatenated with Mesquite v. 3.11. Maximum likelihood (ML) and bayesian inference (BI) were used for phylogenetic tree inference. The ML and BI analyses were performed with RAxML-HPC v.8 and MrBayes on XSEDE in CIPRES Science Gateway, respectively (Miller et al. 2010, 2015). Six simultaneous Markov chains were run for one million generations and trees were sampled every 100 generation (resulting in 10000 trees). The first 2500 trees, representing the burn-in phase of the analyses, were discarded and the remaining 7500 trees were used for calculating posterior probabilities (PP) in the majority rule consensus tree (Larget \& Simon 1999). Phylogenetic trees were viewed with FigTree v. 1.4.03 
(http://tree.bio.ed.ac.uk/) and edited with Microsoft Office PowerPoint 2007 (Microsoft Corporation, WA, United States).

\section{Results}

\section{Phylogenetic analyses}

A combined LSU, ITS, TEF and RPB2 sequence dataset was analysed for species of Diaporthomycetidae. The dataset comprised 302 strains with an alignment length of 4094 total characters. The RAxML analysis resulted in a best scoring likelihood tree selected with a final value for the combined dataset $\ln \mathrm{L}=-106812.195770$. The matrix had 3085 distinct alignment patterns, with $58.07 \%$ of undetermined characters or gaps. Estimated base frequencies are as follows: $\mathrm{A}=0.241268, \mathrm{C}=0.258993, \mathrm{G}=0.286731, \mathrm{~T}=0.213008$; substitution rates $\mathrm{AC}=$ 1.360157, $\mathrm{AG}=2.912312, \mathrm{AT}=1.476237, \mathrm{CG}=1.108880, \mathrm{CT}=7.249310, \mathrm{GT}=1.000000$; gamma distribution shape parameter $\mathrm{a}=0.430061$. All phylogenetic trees $(\mathrm{ML}$ and $\mathrm{BI})$ were similar in topologies, and the RAxML tree is shown in Fig. 1.

Clade 1 represents the order Conlariales with a single family Conlariaceae, which accommodates two genera Conlarium and Riomyces. Riomyces clusters within Conlarium but they have entirely different morphological characteristics (Ferrer et al. 2012, Liu et al. 2012). We introduce one new species C. subglobosum and add one new strain MFLUCC 18-1417 of $C$. aquaticum based on morphology and phylogeny.

Clade 2 represents the order Sporidesmiales with a single family Sporidesmiaceae. We introduce two new species $S$. appendiculatum and $S$. chiangmaiense, which cluster with $S$. minigelatinosa with moderate bootstrap support.

Clade 3 represents the new genus Aquidictyomyces, typified by A. appendiculatus, which clusters with Trichosphaeriaceae with weak bootstrap support. Aquidictyomyces phylogenetically belongs in the subclass Diaporthomycetidae, but referred to Diaporthomycetidae genera incertae sedis.

Clade 4 represents the family Junewangiaceae with three genera Dictyosporella, Junewangia and Sporidesmiella. Dictyosporella clusters with Junewangia but they are not well-separated. The polyphyletic nature of Dictyosporella and Junewangia are shown in clade 4. The new species Dictyosporella chiangmaiensis and new collection D. guizhouensis cluster in the same subclade with the type species $D$. aquatica, while the new species $D$. ellipsoidea clusters in the same subclade with Junewangia lamma and J. sphaerospora. The new species Junewangia thailandica clusters in another subclade with $J$. aquatica, J. globulosa and D. hydei. Sporidesmiella species cluster in a well-supported subclade, and herein we introduce a new species S. obovoidia which clusters well with our new collection $S$. hyalosperma.

Clade 5 represents the family Pseudoproboscisporaceae which comprises Diluviicola, Pseudoproboscispora, the new genus Neodiluviicola, and one species Cataractispora receptaculorum, and one unidentified strain R-038. Pseudoproboscisporaceae is referred to Diaporthomycetidae families incertae sedis.

Clade 6 represents the order Atractosporales with a single family Atractosporaceae. Two genera Atractospora and Rubellisphaeria cluster in a well-supported clade. We add a new strain KUMCC 18-0051 of A. ellipsoidea, which clusters with the other two strains A411-3 and R-008 with high bootstrap support.

Clade 7 represents the family Papulosaceae with four genera Brunneosporella, Fluminicola, Papulosa and Wongia. We introduce a new species Fluminicola striata, which forms a basal branch with other Fluminicola species. Fluminicola thailandensis is synonymized with $F$. saprophytica. Papulosaceae is referred to Diaporthomycetidae families incertae sedis.

Clade 8 represents the family Acrodictyaceae with a single genus Acrodictys. We add a new strain MFLUCC 11-0299 of A. porosiseptata collected from freshwater habitat. Acrodictyaceae is referred to Diaporthomycetidae families incertae sedis. 
Clade 9 represents the order Cancellidiales with a single family Cancellidiaceae. We introduce a new species Cancellidium thailandense and add two new strains of $C$. atrobrunneum and $C$. griseonigrum. A new genus Obliquiminima is introduced, which forms a sister clade with Cancellidium with high bootstrap support.

Clade 10 represents the order Annulatascales with a single family Annulatascaceae. The genera in Annulatascaceae do not cluster well but Annulusmagnus and Ascitendus have a good affinity. We introduce three new species Annulatascus chiangmaiensis, Annula. nakhonensis and Annula. songkhlaensis, which cluster well with the type species Annula. velatisporus. Two new genera Fusoidigranularius and Longivarius are introduced in Annulatascaceae because they phylogenetically and morphologically do not belong in Annulatascus, and therefore they are excluded from this genus.

Clade 11 represents the order Distoseptisporales with two families Aquapteridosporaceae and Distoseptisporaceae. Aquapteridosporaceae comprises a single genus Aquapteridospora. Pleurophragmium bambusinum clusters within Aquapteridospora with high bootstrap support but morphologically does not belong in Aquapteridospora. We introduce a new species A. aquatica, which clusters with $P$. bambusinum, but morphologically must be in Aquapteridospora. Distoseptisporaceae comprises a single genus Distoseptispora with our three new species $D$. fasciculata, D. saprophytica and D. songkhlaensis. In addition, D. submersa is synonymized under D. tectonae.

\section{Taxonomy}

Six orders, viz. Annulatascales, Atractosporales, Cancellidiales, Conlariales, Distoseptisporales and Sporidesmiales, four families, viz. Acrodictyaceae, Junewangiaceae, Papulosaceae and Pseudoproboscisporaceae, are reviewed and one Diaporthomycetidae genera incertae sedis Aquidictyomyces is introduced as follows. Classification of annulatascaceae-like taxa in this study is shown in Table 1.

Annulatascales M.J. D’souza, Maharachch. \& K.D. Hyde, Fungal Diversity 72: 212 (2015)

Type family - Annulatascaceae S.W. Wong, K.D. Hyde \& E.B.G. Jones

Notes - Annulatascales was introduced to accommodate a single family Annulatascaceae (Maharachchikumbura et al. 2015). Annulatascales is an interesting order that comprises 20 genera as listed in Maharachchikumbura et al. (2016) and now retain 11 genera in Hyde et al. (2020), including one Annulatascales genera incertae sedis, Clohiesia. Annulatascales has similar morphological characteristics of ascomata, asci and ascospores with many orders/families in Diaporthomycetidae, e.g. Atractosporaceae, Cancellidiales, Conlariales, Junewangiaceae, Papulosaceae, Pseudoproboscisporaceae, Sporidesmiales.

Annulatascaceae S.W. Wong, K.D. Hyde \& E.B.G. Jones, Syst. Ascom. 16(1-2): 18 (1998)

Type genus - Annulatascus K.D. Hyde

Notes - Annulatascaceae represents an assemblage of many genera that are characterized by unilocular ascomata with a neck, cylindrical asci with a massive, $\mathrm{J}$-, refractive, cylindrical to flaring, doughnut-shaped, apical ring and mostly fusiform, hyaline ascospores (Hyde et al. 2020). Maharachchikumbura et al. (2016) accepted 20 genera in the family and some were later transferred to other families or Diaporthomycetidae genera incertae sedis based on molecular data (Zhang et al. 2017, Réblová et al. 2018, Luo et al. 2019). For example, Dictyosporella, which has annulatascaceae-like sexual morph and helicoid conidia, was first transferred to Diaporthomycetidae genera incertae sedis together with an annulatascaceae-like sexual morph (Zhang et al. 2017), and now is placed in Junewangiaceae based on strong molecular evidence (Luo et al. 2019); Diluviicola, which has cylindrical asci with a large apical ring and fusiform ascosporers with polar caps, was transferred to Pseudoproboscisporaceae (Zhang et al. 2017); Pseudoannulatascus, which has ascomata with a long neck, cylindrical asci with a large apical ring, and long fusiform ascospores with sheaths, was transferred to Xenospadicoidaceae (Réblová et al. 
2018). These excluded genera imply that several morphological characteristics, e.g. cylindrical asci with a relatively massive, refractive apical ring and fusiform ascospores, are not detailed enough to classify Annulatascaceae taxa.

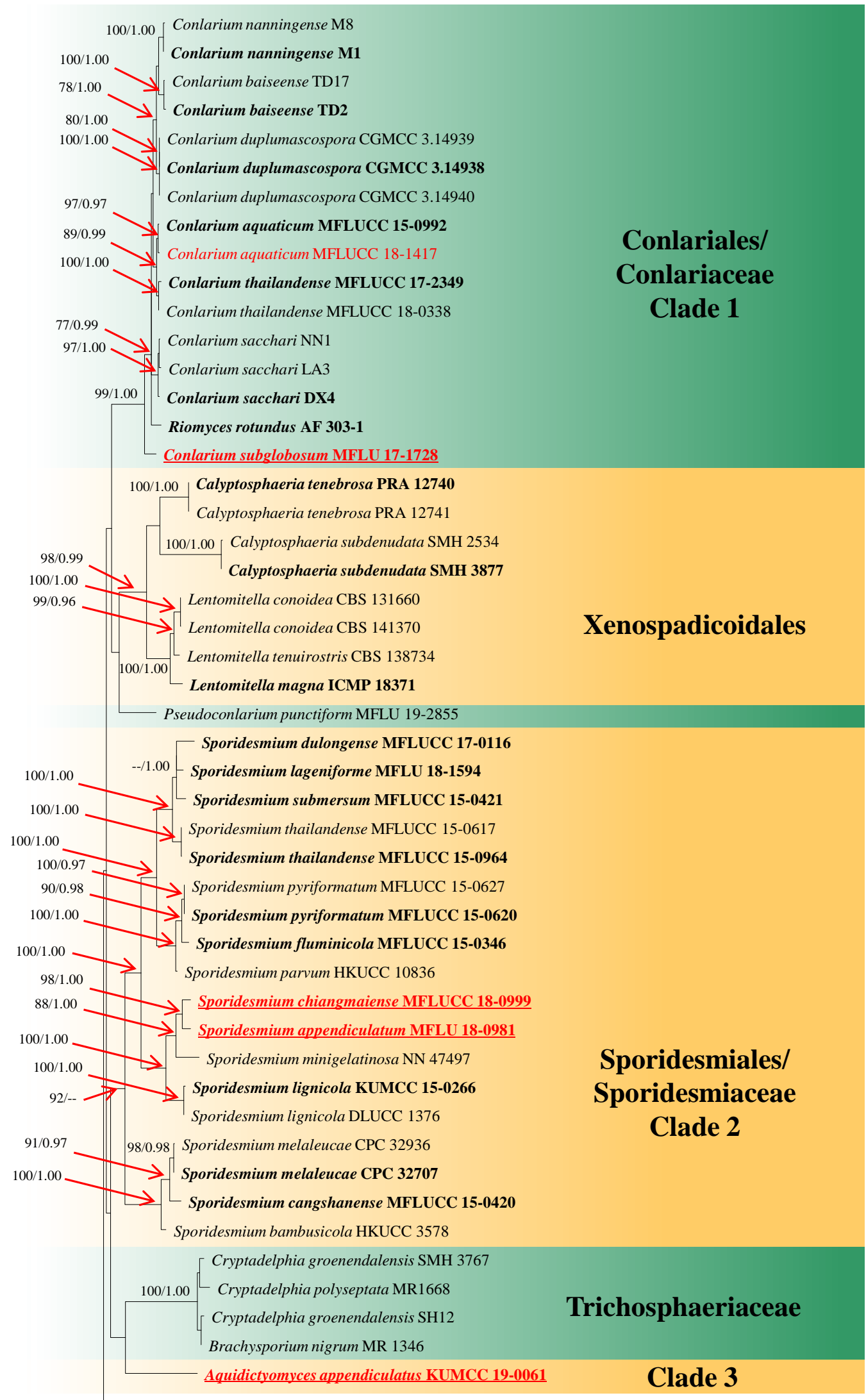

Figure 1 - RAxML tree generated from combined LSU, ITS, TEF and RPB2 sequence data. Bootstrap support values for maximum likelihood (the first value) equal to or greater than $75 \%$ and 
Bayesian posterior probabilities (the second value) equal to or greater than 0.95 are placed near the branches as ML/BYPP. The tree is rooted to Aureobasidium pullulans CBS 584.75 and Dothidea insculpta CBS 189.58. The ex-type strains are indicated in bold and newly generated sequences are indicated in red. The new species introduced in this study are underlined.

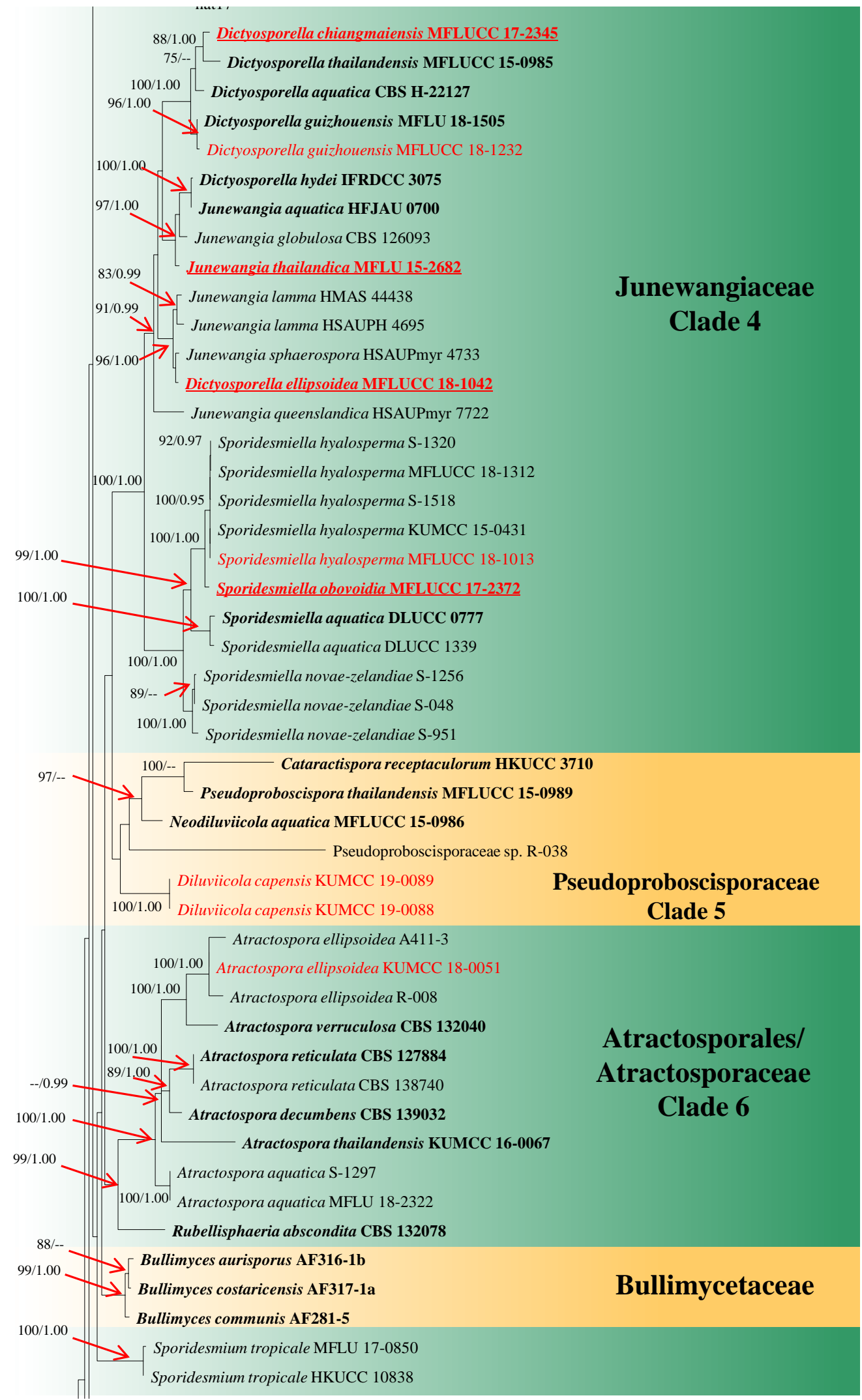

Figure 1 - Continued. 


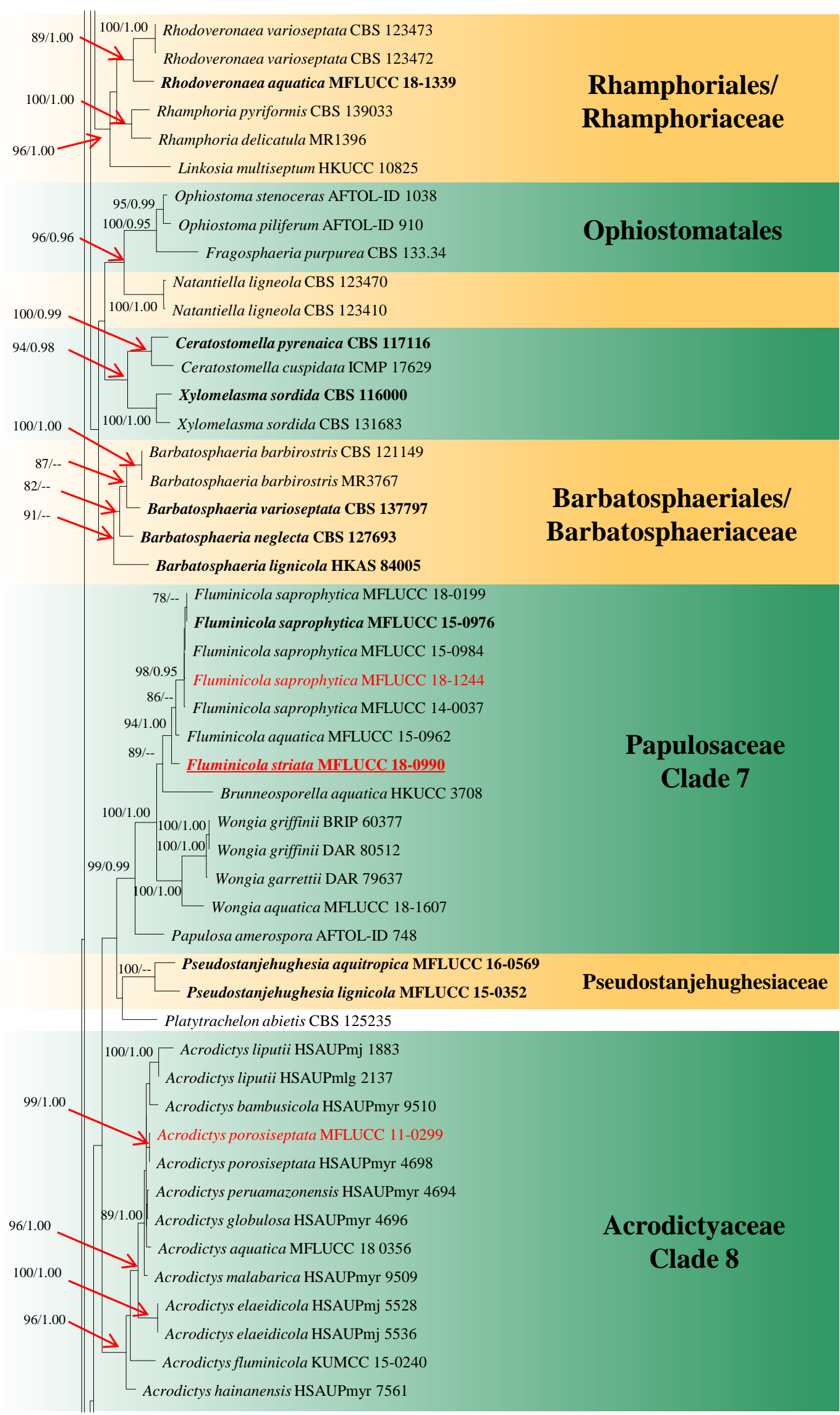

Figure 1 - Continued. 


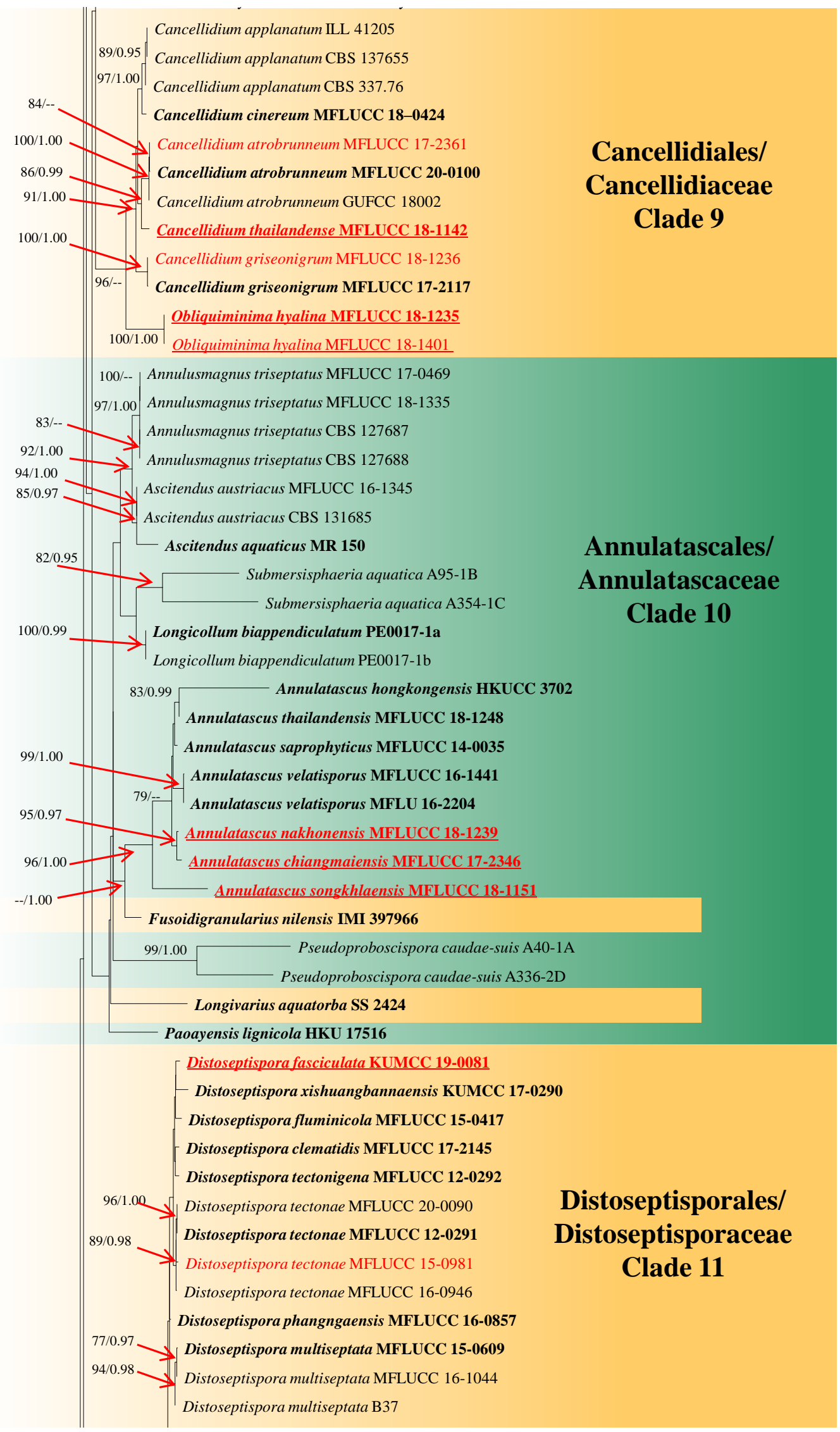

Figure 1 - Continued. 


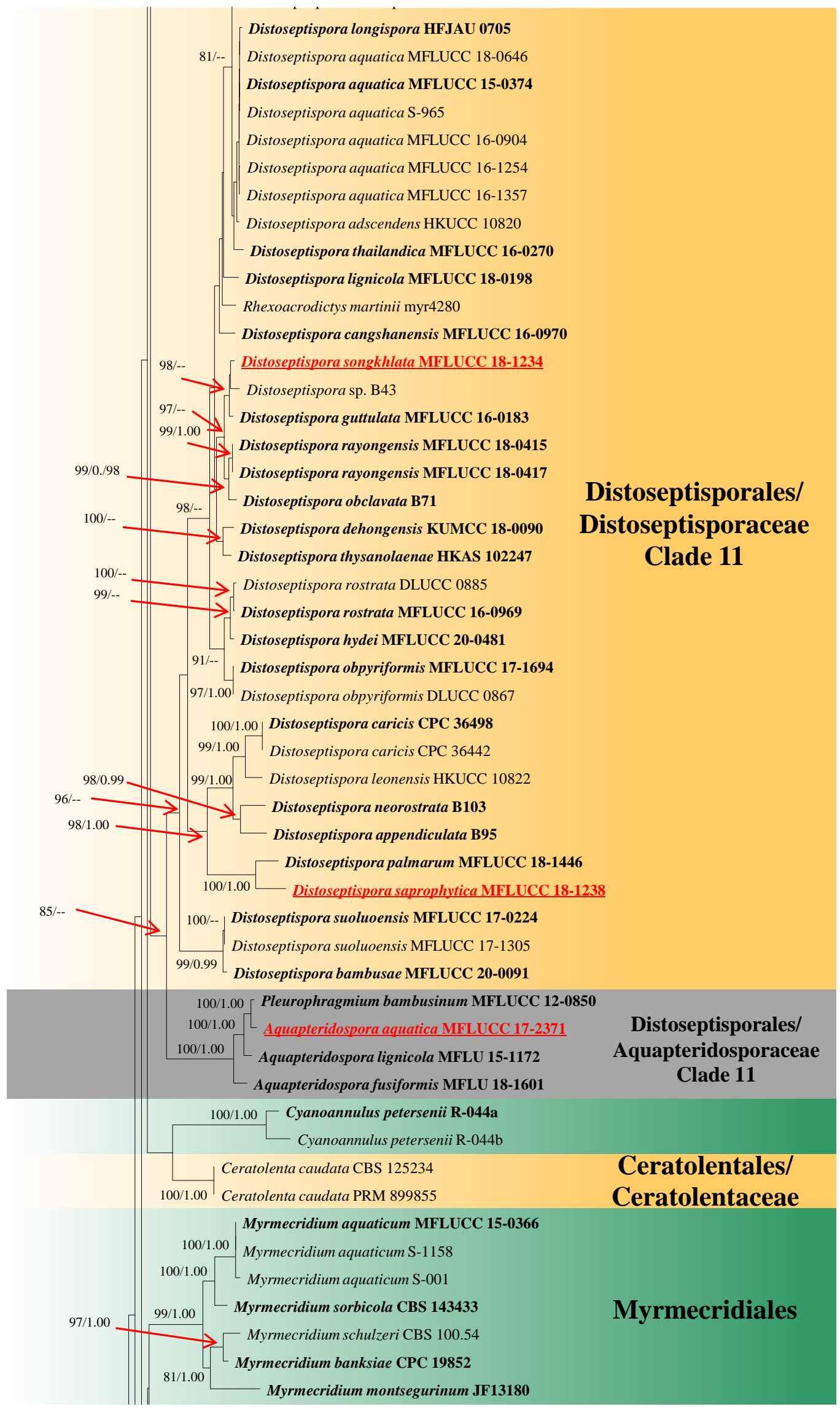

Figure 1 - Continued. 


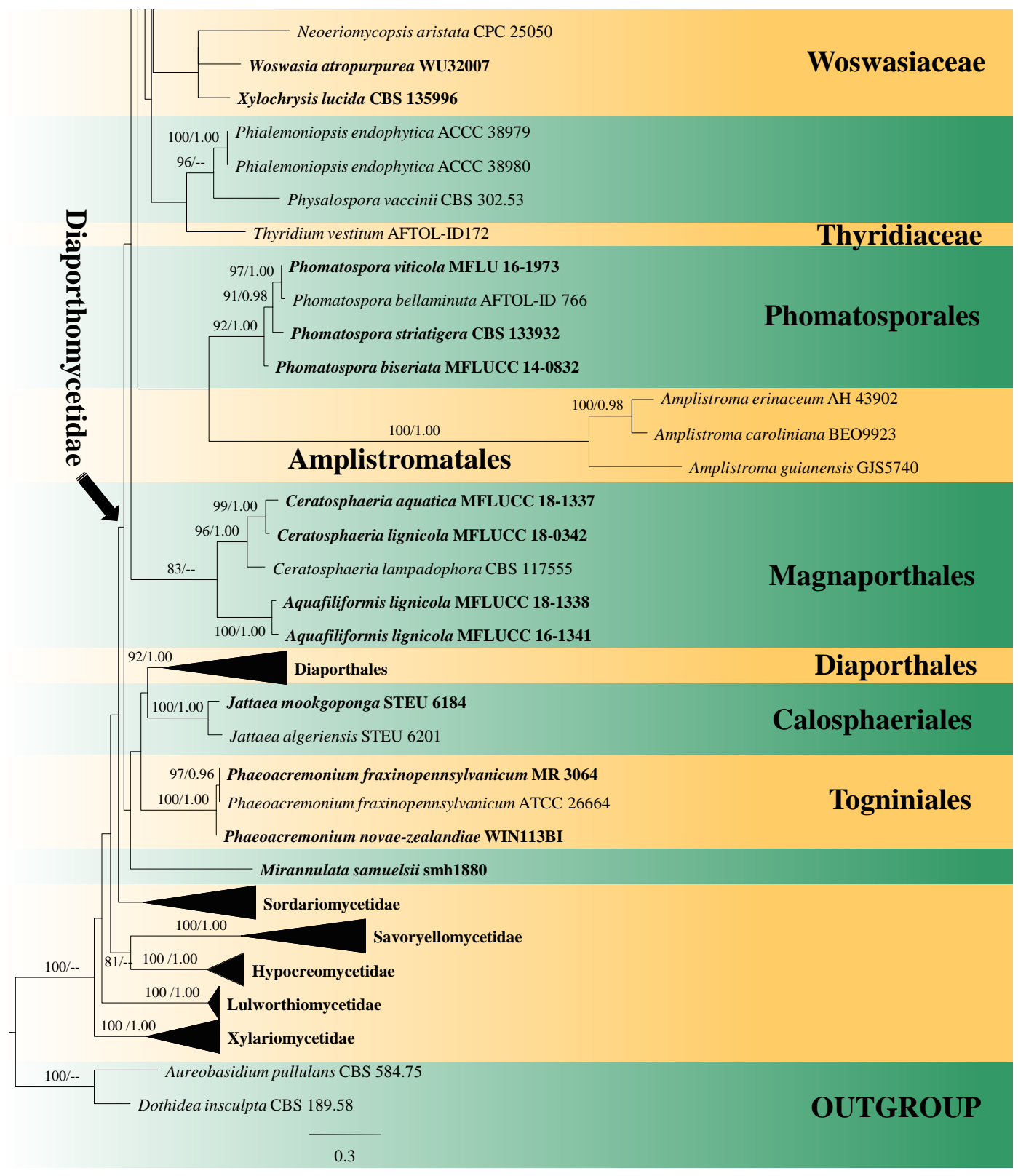

Figure 1 - Continued.

The latest treatment for Annulatascaceae was carried out by Hyde et al. (2020) and they accepted ten genera in the family based on current data. However, only five genera, viz. Annulatascus, Annulusmagnus, Ascitendus, Longicollum and Submersisphaeria, were supported by molecular data. All members of Annulatascaceae form a weakly-supported clade in all studies (Luo et al. 2019, Hyde et al. 2020, this study, Fig. 1). In addition, most taxa only have LSU sequence data in GenBank. Thus, more collections with sufficient DNA sequences are needed to reappraise Annulatascaceae. This study accepts 13 genera in Annulatascaceae including two newly introduced genera Fusoidigranularius and Longivarius, and one genus Aquaticola which was referred to Diaporthomycetidae genera incertae sedis (Table 1).

Annulatascus K.D. Hyde, Aust. Syst. Bot. 5(1): 118 (1992)

Type species - Annulatascus velatisporus K.D. Hyde

Notes - Annulatascus was introduced by Hyde (1992) with A. velatisporus as the type species. Considering the poor condition and the dearth of sequence data of the holotype, an epitype of A. velatisporus was designated with a morphological description and DNA sequence data for the precise delineation of this taxon (Dayarathne et al. 2016). Dayarathne et al. (2016) observed smaller 
ascospores $(22-25 \times 7-9 \mu \mathrm{m}$ vs. 26-42 $\times 9-12 \mu \mathrm{m})$ from the holotype BRIP 17373 and stated that the relatively wide range of ascospore length described by Hyde (1992) might be a result of observing more than one collection.

Table 1 Classification of annulatascaceae-like taxa in this study

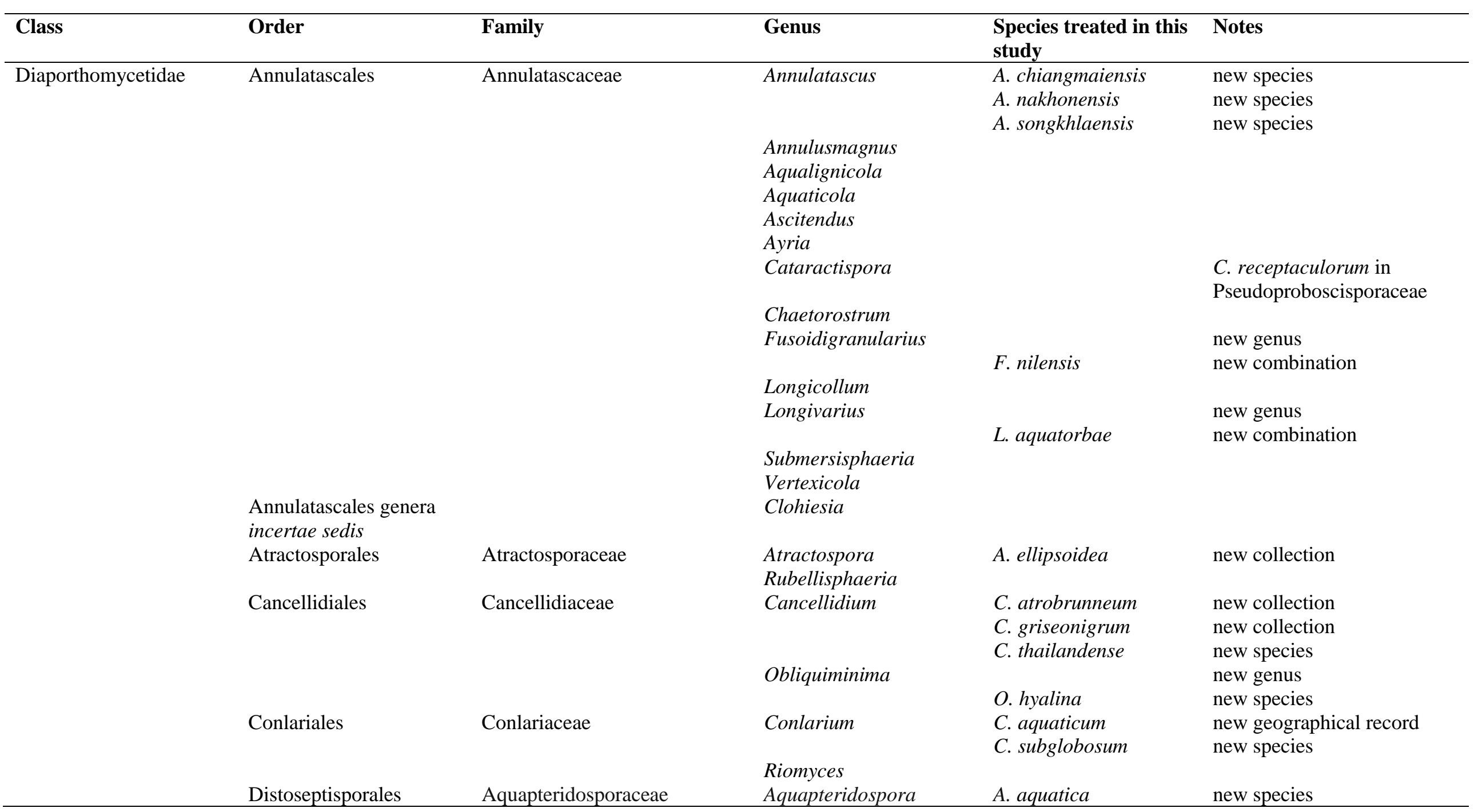


Table 1 Continued.

\begin{tabular}{|c|c|c|c|c|c|}
\hline Class & Order & Family & Genus & $\begin{array}{l}\text { Species treated in this } \\
\text { study }\end{array}$ & Notes \\
\hline & \multirow{6}{*}{ Sporidesmiales } & \multirow[t]{4}{*}{ Distoseptisporaceae } & \multirow[t]{4}{*}{ Distoseptispora } & D. fasciculata & new species \\
\hline & & & & D. saprophytica & new species \\
\hline & & & & D. songkhlaensis & new species \\
\hline & & & & D. tectonae & new synonym \\
\hline & & Sporidesmiaceae & Sporidesmium & S. appendiculatum & new species \\
\hline & & & & S. chiangmaiense & new species \\
\hline & \multirow[t]{17}{*}{$\begin{array}{l}\text { Diaporthomycetidae } \\
\text { families incertae sedis }\end{array}$} & Acrodictyaceae & Acrodictys & A. porosiseptata & $\begin{array}{l}\text { new geographical and } \\
\text { habitat record }\end{array}$ \\
\hline & & \multirow[t]{6}{*}{ Junewangiaceae } & \multirow[t]{3}{*}{ Dictyosporella } & D. chiangmaiensis & new species \\
\hline & & & & D. ellipsoidea & new species \\
\hline & & & & D. guizhouensis & new collection \\
\hline & & & Junewangia & J. thailandica & new species \\
\hline & & & Sporidesmiella & S. hyalosperma & new collection \\
\hline & & & & S. obovoidia & new species \\
\hline & & \multirow[t]{5}{*}{ Papulosaceae } & Brunneosporella & & \\
\hline & & & Fluminicola & F. saprophytica & new synonym \\
\hline & & & & F. striata & new species \\
\hline & & & Papulosa & & \\
\hline & & & Wongia & & \\
\hline & & \multirow[t]{4}{*}{ Pseudoproboscisporaceae } & Cataractispora? & & $\begin{array}{l}\text { Pending awaiting sequence } \\
\text { data from } C \text {. aquatica }\end{array}$ \\
\hline & & & Diluviicola & D. capensis & new geographical record \\
\hline & & & Neodiluviicola & & new genus \\
\hline & & & & N. aquatica & new combination \\
\hline \multirow{3}{*}{$\begin{array}{l}\text { Diaporthomycetidae } \\
\text { genera incertae sedis }\end{array}$} & & & Pseudoproboscispora & & \\
\hline & & & Aquidictyomyces & & new genus \\
\hline & & & & A. appendiculatus & new species \\
\hline
\end{tabular}

Several strains, i.e. A70-18, HKUCC 3701, R047, PE0011-9a, PE0011-9b and PE0011-9c, named under Annulatascus velatisporus are deposited in GenBank and they clustered with ex-epitype strains MFLU 16-2204 and MFLUCC 16-1441 in a clade with moderate bootstrap support (Dayarathne et al. 2016). However, all these strains clustered separately from ex-epitype strains in different clades in Hyde et al. (2020) and our preliminary phylogenetic tree (data not shown). Strains A70-18, HKUCC 3701 and R047 are likely to be other different species based on a comparison of DNA sequence data from single gene and phylogenetic analyses (Hyde et al. 2020, our preliminary analysis), but their morphs were not described in 
Ranghoo et al. (1999) and Raja et al. (2003). Three strains PE0011-9a, PE0011-9b and PE0011-9c were sequenced by Dayarathne et al. (2016), but their morphs were not specifically described and illustrated in the dissertation of Zelski (2015). Because these six strains were not formally published and our preliminary multigene analysis show that they are phylogenetically different species to A. velatisporus, we exclude them and retain the ex-epitype strains of A. velatisporus (MFLU 16-2204 and MFLUCC 16-1441) in our phylogenetic tree (Fig. 1).

Annulatascus comprises 20 epithets in Index Fungorum (2021) and its polyphyletic nature has been shown in previous studies (Luo et al. 2015, Zhang et al. 2017, Hyde et al. 2020) and in this study (Fig. 1). The latest treatment for Annulatascus was provided by Hyde et al. (2020). The phylogenetic placements of most Annulatascus species have not been confirmed by molecular data. Presently, six sequenced species of Annulatascus cluster in Annulatascaceae, but A. aquatorbae and A. nilensis are phylogenetically distant from the type species A. velatisporus (Luo et al. 2015, Hyde et al. 2020, this study, Fig. 1). Based on morphology and phylogeny, A. aquatorbae and A. nilensis are excluded from Annulatascus and transferred to two new genera, Fusoidigranularius and Longivarius, respectively (see notes under Fusoidigranularius and Longivarius). In addition, we introduce three new species in Annulatascus, which were collected from submerged wood in freshwater in Thailand.

Annulatascus chiangmaiensis X.D. Yu, W. Dong \& H. Zhang, sp. nov.

Fig. 2

Index Fungorum number: IF557443; Facesoffungi number: FoF 09541

Etymology - referring to Chiang Mai, where the holotype was collected

Holotype - MFLU 17-1708

Saprobic on submerged wood in freshwater. Sexual morph: Ascomata 330-380 $\mu \mathrm{m}$ high, 260-300 $\mu \mathrm{m}$ diam., scattered, superficial, pyriform to subglobose, black, carbonaceous, ostiolate, with a centric or ecentric neck. Necks $125-150 \times 80-100 \mu \mathrm{m}$, black, often oblique to host substrate. Peridium 45-80 $\mu \mathrm{m}$ thick, comprising several layers of dark brown to black, thick-walled cells of textura angularis, with inwardly compressed cells. Paraphyses up to $7.2 \mu \mathrm{m}$ diam. at the widest, tapering towards the apex, dense, hypha-like, septate, constricted at septa, unbranched, hyaline. Asci $190-375 \times 9.5-10.5 \mu \mathrm{m}(\bar{x}=295 \times 10 \mu \mathrm{m}, \mathrm{n}=5), 8$-spored, unitunicate, cylindrical, apex truncate, with a large, refractive, wedge-shaped, apical ring, 4-7.5 $\times 5-7 \mu \mathrm{m}$, long pedicellate, up to $160 \mu \mathrm{m}$ long. Ascospores 20-30 ×6-8 $\mu \mathrm{m}(\bar{x}=25 \times 7.2 \mu \mathrm{m}, \mathrm{n}=20)$, uniseriate, fusiform, slightly curved, mostly aseptate, obscurely 1 -septate when germinated, minutely guttulate, hyaline, thinwalled, smooth, sometimes with bipolar, short, cellular, tapering, hyaline apiculi, without gelatinous sheath. Asexual morph: Undetermined.

Material examined - Thailand, Chiang Mai Province, Mushroom Research Centre, on submerged wood in a stream, 1 September 2017, X.D. Yu, 23A (MFLU 17-1708, holotype), extype living culture MFLUCC 17-2346.

Notes - The ascospores of Annulatascus chiangmaiensis are sometimes equipped with a short, cellular apiculi, which are similar to A. apiculatus (Barbosa et al. 2008). However, A. apiculatus has immersed to semi-immersed ascomata with a long neck, constrasting with the superficial ascomata with a short neck of $A$. chiangmaiensis. In addition, A. chiangmaiensis has longer asci $(190-375 \times 9.5-10.5 \mu \mathrm{m}$ vs. $175-250 \times 10-13 \mu \mathrm{m})$, wider ascal apical ring $(4-7.5 \times 5-$ $7 \mu \mathrm{m}$ vs. $6-7.2 \times 1.8-2.4 \mu \mathrm{m})$ and smaller ascospores $(20-30 \times 6-8 \mu \mathrm{m}$ vs. $23-36.5 \times 8.8-10 \mu \mathrm{m})$. Annulatascus apiculatus has 0-3-septate ascospores, while A. chiangmaiensis has obscurely 1septate ascospores at maturity. Sequence data of $A$. apiculatus are lacking, but the two species can be separated by distinct morphology.

The morphological characteristics of Annulatascus chiangmaiensis, such as cylindrical asci with a long pedicel and wedge-shaped apical ring, fusiform, hyaline ascospores with bipolar, short apiculi, are similar to Dictyosporella thailandensis (Zhang et al. 2017). However, D. thailandensis differs in having immersed ascomata, an indistinct, small apical ring and 3-septate ascospores. Phylogenetic analysis places A. chiangmaiensis in Annulatascaceae, while D. thailandensis in Junewangiaceae (Fig. 1). 

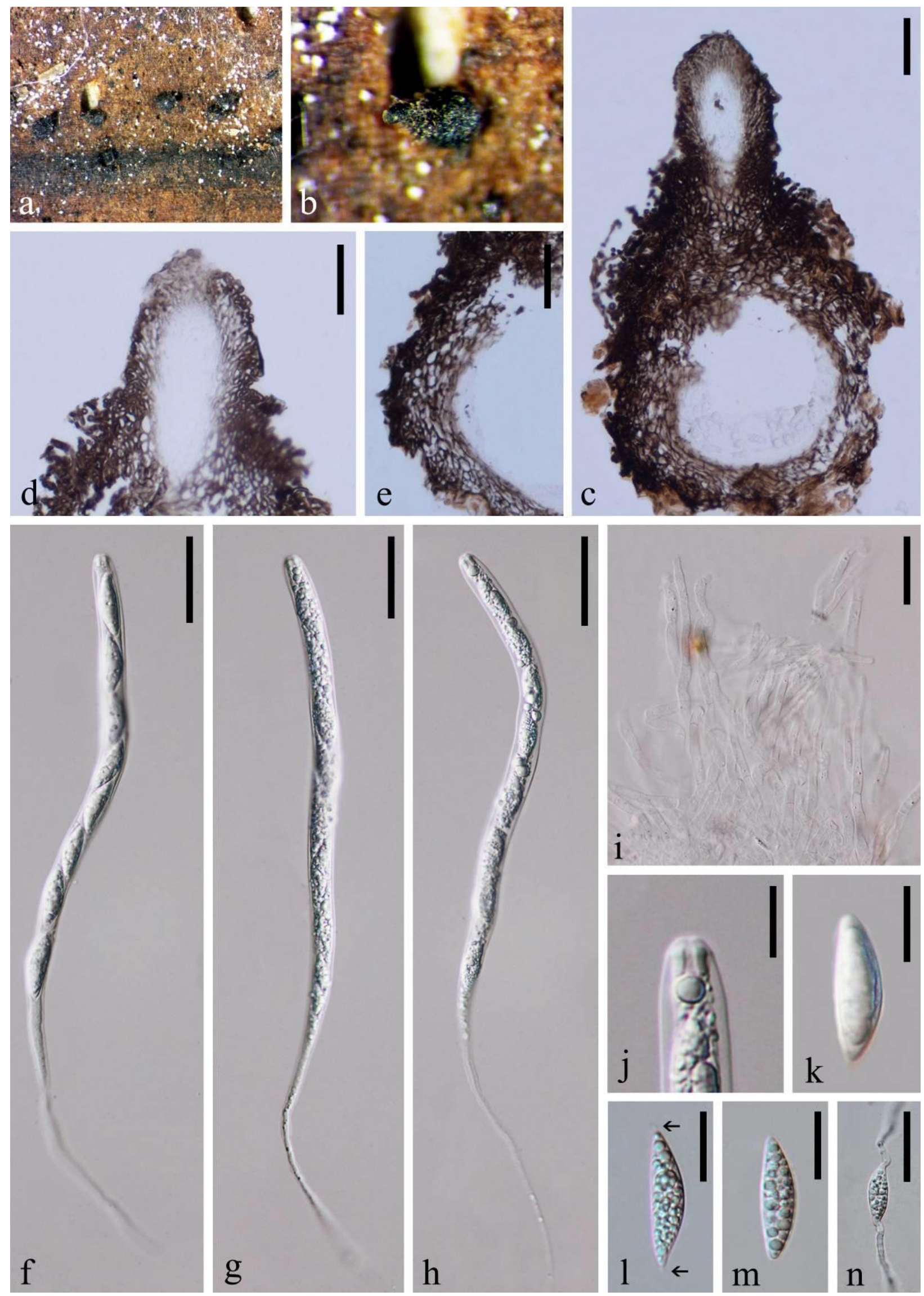

Figure 2 - Annulatascus chiangmaiensis (MFLU 17-1708, holotype). a, b Ascomata on host substrate. c Vertical section of ascoma. d Structure of neck. e Structure of peridium. $\mathrm{f}-\mathrm{h}$ Unitunicate asci. i Paraphyses. j Apical ring. $\mathrm{k}-\mathrm{m}$ Ascospores (1 note the bipolar apiculi). $\mathrm{n}$ Germinated ascospore. Scale bars: $\mathrm{c}-\mathrm{i}=50 \mu \mathrm{m}, \mathrm{j}-\mathrm{m}=15 \mu \mathrm{m}, \mathrm{n}=30 \mu \mathrm{m}$. 
Annulatascus nakhonensis W. Dong, H. Zhang \& K.D. Hyde, sp. nov.

Index Fungorum number: IF557444; Facesoffungi number: FoF 09542

Etymology - referring to Nakhon Si Thammarat, where the holotype was collected

Holotype - MFLU 18-1543

Saprobic on submerged wood in freshwater. Sexual morph: Ascomata 275-375 $\mu \mathrm{m}$ high, 320-325 $\mu \mathrm{m}$ diam., scattered to gregarious, semi-immersed, often lying horizontally to the host substrate, ellipsoidal or subglobose, black, coriaceous, with a lateral neck. Necks $80-120 \times 45-55$ $\mu \mathrm{m}$, black, conical, oblique to host substrate. Peridium 35-80 $\mu \mathrm{m}$ thick, uneven in thickness, comprising several layers of thin-walled cells of textura angularis, outer layer dark brown with compressed cells, inwardly hyaline with large cells. Paraphyses 5-6 $\mu \mathrm{m}$ diam., sparse, hypha-like, septate, slightly constricted at septa, unbranched, hyaline. Asci $240-340 \times 10-13 \mu \mathrm{m}(\bar{x}=285 \times$ $11.5 \mu \mathrm{m}, \mathrm{n}=10$ ), 8-spored, unitunicate, cylindrical, apex rounded, with a large, refractive, wedgeshaped, apical ring, 4-4.3 $\times 5.3-5.5 \mu \mathrm{m}$, long pedicellate, up to $120 \mu \mathrm{m}$ long. Ascospores $24-28.5 \times$ $8-10 \mu \mathrm{m}(\bar{x}=26.8 \times 9.2 \mu \mathrm{m}, \mathrm{n}=10)$, uniseriate, fusiform, straight or curved, aseptate, minutely guttulate, hyaline, thin-walled, smooth, with a gelatinous, thin sheath that is often folded at one side, showing an entirely covered, ellipsoidal, mucilaginous sheath in Indian Ink. Asexual morph: Undetermined.

Culture characteristics - On PDA, colony circular, reaching $20 \mathrm{~mm}$ in 25 days at $25^{\circ} \mathrm{C}$, white from above, yellowish white from below, surface rough, dry, with sparse mycelium, umbonate, entire at edge.

Material examined - Thailand, Nakhon Si Thammarat Province, on submerged wood in a stream, 10 May 2018, W. Dong, hat670 (MFLU 18-1543, holotype), ex-type living culture MFLUCC 18-1239; ibid., HKAS 105013, isotype, ex-isotype living culture KUMCC 19-0029.

Notes - Annulatascus nakhonensis clusters with A. chiangmaiensis with high bootstrap support (Fig. 1). Both species have fusiform, hyaline, aseptate ascospores, but they can be distinguished by several aspects. Annulatascus nakhonensis has semi-immersed ascomata, ascospores with a gelatinous, often folded sheath and without appendages. In contrast, $A$. chiangmaiensis has superficial ascomata, ascospores with bipolar, short, cellular apiculi and without gelatinous sheath. A nucleotide comparison between A. nakhonensis and A. chiangmaiensis shows a difference of 6 and 18 nucleotides in LSU and ITS sequence data, respectively, which indicates that they are distinct species according to guidelines of Jeewon \& Hyde (2016).

Annulatascus songkhlaensis W. Dong, H. Zhang \& K.D. Hyde, sp. nov.

Fig. 4

Index Fungorum number: IF557445; Facesoffungi number: FoF 09543

Etymology - referring to songkhla, where the holotype was collected

Holotype - MFLU 18-1564

Saprobic on submerged wood in freshwater. Sexual morph: Ascomata 180-200 $\mu \mathrm{m}$ high, 290-310 $\mu \mathrm{m}$ diam., scattered to gregarious, immersed with neck erumpent through host substrate, ellipsoidal, black, coriaceous, ostiolate, with a centric or lateral neck. Necks 100-130 × 55-85 $\mu$ m, black, subcylindrical or conical, tapering towards apex, oblique or upright to host substrate. Peridium 20-40 $\mu \mathrm{m}$ thick, comprising 11-14 layers of thick-walled cells of textura angularis, outer layer dark brown to black with large cells, inwardly pale brown to hyaline, with compressed cells. Paraphyses up to $7.5 \mu \mathrm{m}$ diam. at the base, tapering towards the apex, dense, hypha-like, septate, slightly constricted at septa, unbranched, hyaline. Asci $285-355 \times 11-12 \mu \mathrm{m}(\bar{x}=315 \times 11.2 \mu \mathrm{m}, \mathrm{n}$ $=10$ ), 8-spored, unitunicate, cylindrical, apex truncate, long pedicellate, with a large, refractive, wedge-shaped, apical ring, 5-5.5 × 6.5-6.7 $\mu \mathrm{m}$. Ascospores 30-35 $\times 9-10.5 \mu \mathrm{m}(\bar{x}=32 \times 9.9 \mu \mathrm{m}$, $\mathrm{n}=20$ ), uniseriate, fusiform, straight or slightly curved, aseptate or occasionally 1-septate, not constricted at the septum, minutely guttulate, hyaline, thin-walled, smooth, with an irregular, mucilaginous sheath, sometimes with short, cellular, tapering, hyaline apiculi at one or both ends. Asexual morph: Undetermined.

Culture characteristics - On PDA, colony circular, reaching $15 \mathrm{~mm}$ in 13 days at $25^{\circ} \mathrm{C}$, gray from above, dark brown from below, surface rough, dry, with sparse mycelium, flat, entire at edge. 
Material examined - Thailand, Songkhla Province, on submerged wood in a stream, 10 May 2018, W. Dong, hat826 (MFLU 18-1564, holotype), ex-type living culture MFLUCC 18-1151; ibid., HKAS 105004, isotype, ex-isotype living culture KUMCC 19-0020.
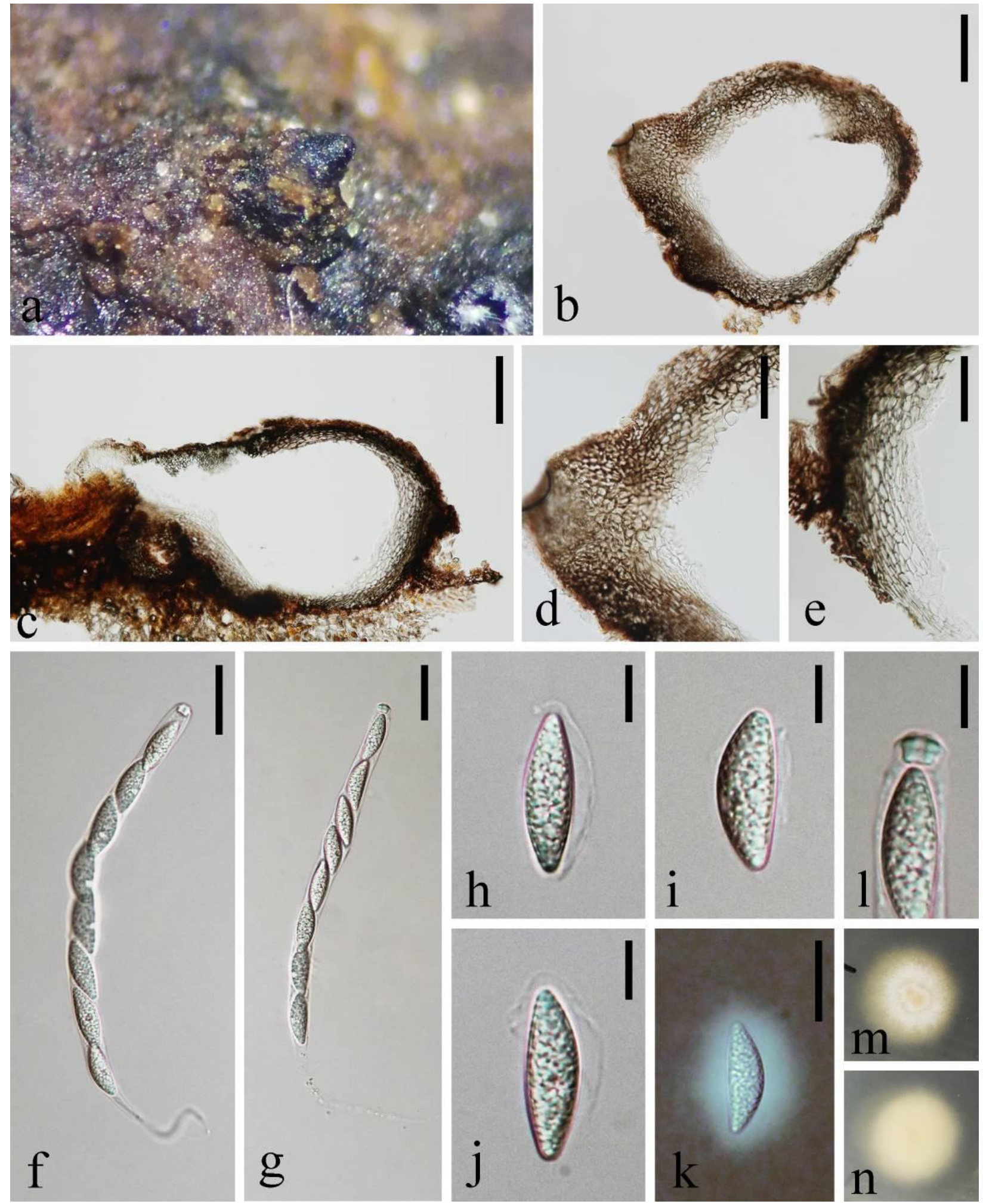

Figure 3 - Annulatascus nakhonensis (MFLU 18-1543, holotype). a Appearance of necks of ascomata on host. b, c Vertical section of ascomata. d, e Structure of peridium. f, g Unitunicate asci. $h-j$ Ascospores in water showing folded sheaths. $k$ Ascospore in Indian Ink showing an entire sheath. 1 Apical ring. $\mathrm{m}, \mathrm{n}$ Colony on PDA (up-front, down-reverse). Scale bars: $\mathrm{b}, \mathrm{c}=100 \mu \mathrm{m}$, $\mathrm{d}, \mathrm{e}=50 \mu \mathrm{m}, \mathrm{f}, \mathrm{g}=30 \mu \mathrm{m}, \mathrm{h}-\mathrm{j}, \mathrm{l}=10 \mu \mathrm{m}, \mathrm{k}=20 \mu \mathrm{m}$. 

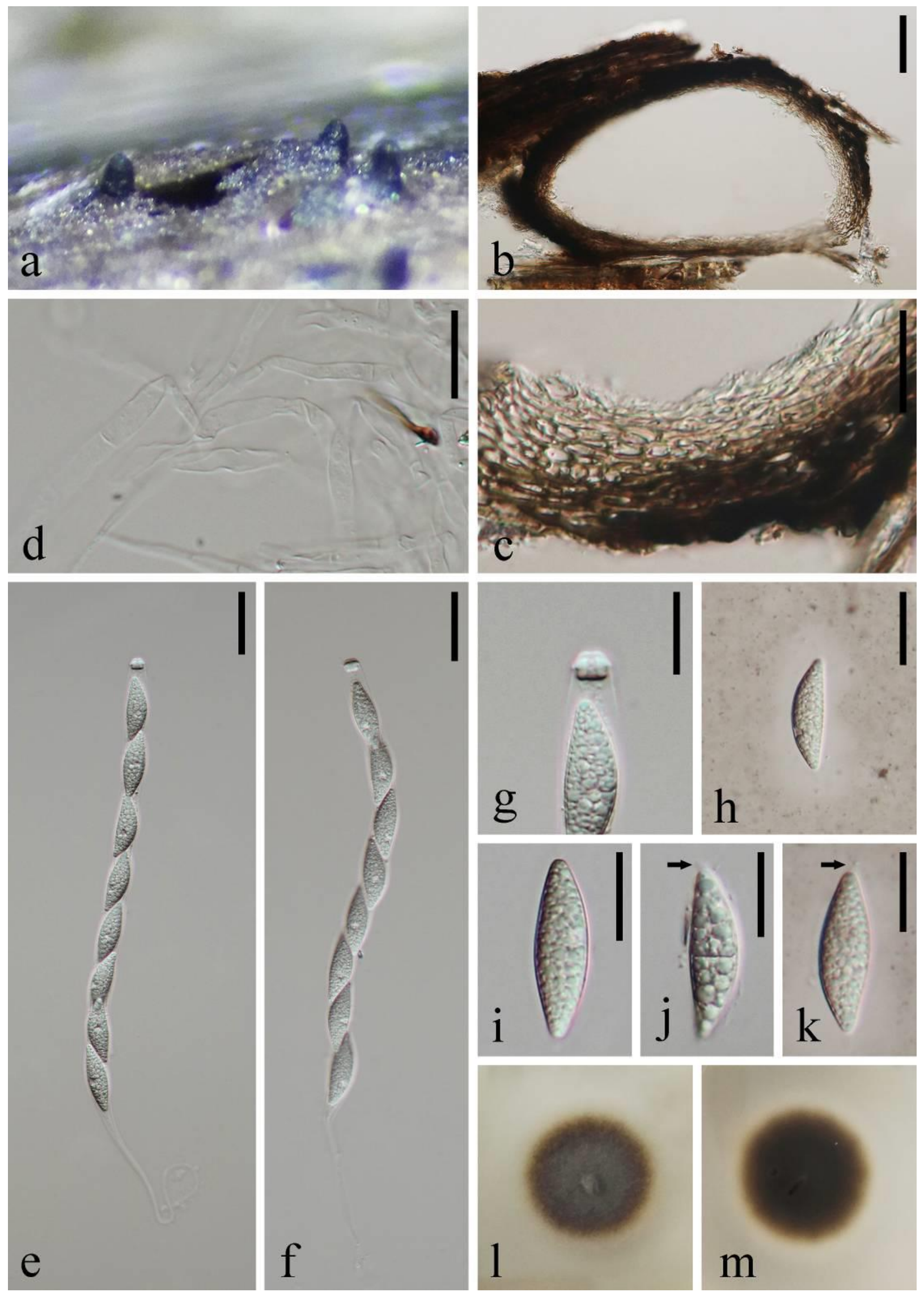

Figure 4 - Annulatascus songkhlaensis (MFLU 18-1564, holotype). a Appearance of necks of ascomata on host. b Vertical section of ascoma. c Structure of peridium. d Paraphyses. $\mathrm{e}, \mathrm{f}$ Unitunicate asci. g Apical ring. $\mathrm{h}-\mathrm{k}$ Ascospores ( $\mathrm{h}, \mathrm{k}$ ascospores in Indian Ink showing the 
irregular, mucilaginous sheath; $\mathrm{j}$, $\mathrm{k}$ note the short apiculi as arrowed). 1, m Colony on PDA (leftfront, right-reverse). Scale bars: $\mathrm{b}=50 \mu \mathrm{m}, \mathrm{c}, \mathrm{d}, \mathrm{h}=20 \mu \mathrm{m}, \mathrm{e}, \mathrm{f}=30 \mu \mathrm{m}, \mathrm{g}, \mathrm{i}-\mathrm{k}=15 \mu \mathrm{m}$.

Notes - Annulatascus songkhlaensis is basal to other Annulatascus species in our multigene phylogeny (Fig. 1). Annulatascus songkhlaensis is similar to A. chiangmaiensis in having short, cellular apiculi at one or both ends of ascospores, but they can be distinguished by the ascospore size $(30-35 \times 9-10.5 \mu \mathrm{m}$ vs. 20-30 × 6-8 $\mu \mathrm{m})$. Annulatascus songkhlaensis has immersed ascomata with neck erumpent through host substrate, while A. chiangmaiensis has superficial ascomata. Molecular evidence supports them to be different species (Fig. 1). Annulatascus songkhlaensis has similar ascospore size with A. apiculatus, and both species have a short, cellular apiculi (Barbosa et al. 2008). However, A. songkhlaensis has longer asci (285-355 $\times 11-12 \mu \mathrm{m}$ vs. 175-250 × 10-13 $\mu \mathrm{m})$, wider apical ring $(5-5.5 \times 6.5-6.7 \mu \mathrm{m}$ vs. 6-7.2 $\times 1.8-2.4 \mu \mathrm{m})$ and less septate of ascospores (mostly 1-septate vs. 0-3-septate) than A. apiculatus.

Aquaticola W.H. Ho, C.K.M. Tsui, Hodgkiss \& K.D. Hyde, Fungal Diversity Res. Ser. 3: 88 (1999)

Type species - Aquaticola hyalomura W.H. Ho, C.K.M. Tsui, Hodgkiss \& K.D. Hyde

Notes - Aquaticola was introduced to accommodate A. ellipsoidea and A. hyalomura (type), which were collected from wood submerged in freshwater (Ho et al. 1999b). Aquaticola ellipsoidea was later transferred to Atractospora based on original description and two reference sequences (Réblová et al. 2016). Aquaticola is characterized by white to dark brown ascomata with a cylindrical neck, broadly oblong to long cylindrical asci with rounded to truncate apex, with a small apical ring, and ellipsoidal, septate or aseptate ascospores, with or without a sheath (Ho et al. 1999b). However, the features are shown to be broad and Aquaticola is an obviously heterogeneous assemblage as four accepted species represent different morphotypes (Ho et al. 1999b, Tsui et al. 2003).

Aquaticola was placed in Annulatascaceae by Maharachchikumbura et al. (2016). It was later referred to Diaporthomycetidae genera incertae sedis, because of the unstable relationship of the type species A. hyalomura (R-038) in phylogenetic and evolutionary analyses (Zhang et al. 2017). However, Réblová et al. (2016) indicated that the specimen R038 collected by Campbell \& Shearer (2004) was misidentified and confirmed by its author Carol Shearer. Thus, there is no evidence to infer the phylogenetic placement of A. hyalomura. Due to their heterogeneous morphology and lack of DNA evidence derived from all Aquaticola species, we follow Maharachchikumbura et al. (2016) and retain Aquaticola in Annulatascaceae until more evidence appears. The strain R-038 is named as Pseudoproboscisporaceae sp. in our phylogenetic tree (Fig. 1).

Fusoidigranularius W. Dong, H. Zhang \& K.D. Hyde, gen. nov.

Index Fungorum number: IF557491; Facesoffungi number: FoF 09544

Etymology - in reference to its fusoid ascospores with a large granular sheath

Saprobic on submerged wood. Sexual morph: Ascomata solitary or gregarious, immersed, obpyriform, oriented horizontally to the host substrate, black, coriaceous, with ostiolate papilla, with an upward bend, relatively long neck growing laterally, periphysate. Peridium comprising several layers of thick-walled, flattened cells of textura angularis, outer layer dark brown and encrusted with pigmented particles, hyaline and unencrusted inwardly. Paraphyses rarely septate, hyaline, unbranched, tapering distally. Asci 8-spored, unitunicate, cylindrical, long pedicellate, persistent, with a large, refractive, J-, apical ring. Ascospores uniseriate to overlapping uniseriate, fusoid, 5-9(-11)-septate, hyaline, smooth-walled, with a large, gelatinous, irregular, granular sheath. Asexual morph: Undetermined.

Type species - Fusoidigranularius nilensis (Abdel-Wahab \& Abdel-Aziz) W. Dong, H. Zhang \& K.D. Hyde

Notes - Annulatascus nilensis was collected from submerged stems of Phragmites australis in the river Nile in Egypt (Abdel-Wahab et al. 2011). It clustered with Annulatascus species with 
weak bootstrap support, and was placed in Annulatascus based on limited data (Abdel-Wahab et al. 2011). Annulatascus nilensis appears to have typical morphological characteristics of Annulatascus, such as cylindrical asci, long pedicel, and a large, refractive apical ring (Abdel-Wahab et al. 2011). However, A. nilensis has immersed ascomata that oriented horizontally to the host substrate and with an upwardly bending neck growing laterally, which are distinctive from Annulatascus, and even from Annulatascaceae. In addition, A. nilensis has 5-9(-11)-septate ascospores with an irregular, granular sheath that differ from Annulatascus species, including our three new species. Phylogenetically, A. nilensis forms a separated clade from Annulatascus in our updated phylogenetic tree (Fig. 1), which corroborates other studies (Hyde et al. 2018, 2020, Luo et al. 2019). The new genus Fusoidigranularius is, therefore, established to accommodate A. nilensis based on distinct morphology and phylogenetic analyses.

The ascomata lying horizontally is the key feature of two annulatascaceae-like families, Atractosporaceae and Pseudoproboscisporaceae. However, the ascomata of Atractosporaceae and Pseudoproboscisporaceae are semi-immersed to nearly superficial and they have aseptate or few septate ascospores (Zhang et al. 2017). A new collection of Fluminicola saprophytica (MFLUCC 18-1244) found in this study also has immersed ascomata that oriented horizontally to the host substrate and with an upward bend neck growing laterally (Fig. 26), which are similar to Fusoidigranularius. However, they can be distinguished by septation and shape of ascospores. Although Fusoidigranularius has a weak relationship with Annulatascaceae members (Fig. 1), it is temporarily placed in Annulatascaceae based on current phylogenetic analysis.

Fusoidigranularius nilensis (Abdel-Wahab \& Abdel-Aziz) W. Dong, H. Zhang \& K.D. Hyde, comb. nov.

Index Fungorum number: IF557492; Facesoffungi number: FoF 09545

Basionym - Annulatascus nilensis Abdel-Wahab \& Abdel-Aziz, IMA Fungus 2(1): 3 (2011)

Holotype - IMI 397966

Known distribution (based on molecular data) - Egypt

Known habitat (based on molecular data) - freshwater

For description of this fungus see Abdel-Wahab et al. (2011)

Longivarius W. Dong, H. Zhang \& K.D. Hyde, gen. nov.

Index Fungorum number: IF557493; Facesoffungi number: FoF 09546

Etymology - in reference to its long neck and various colour of ascospore cells

Saprobic on submerged wood. Sexual morph: Ascomata solitary, semi-immersed or superficial, globose, brown to dark brown, ostiolate, periphysate, with a prominent neck. Neck relatively long, cylindrical, curving or becoming erect. Peridium thick-walled, brown, comprising pseudoparenchymatous cells. Paraphyses filiform, septate, hyaline, simple to rarely branched. Asci 8-spored, unitunicate, cylindrical, short pedicellate, with a distinct, wedge-shaped, J-, apical ring. Ascospores uniseriate to overlapping biseriate in the ascus, fusoid to lunate, straight to slightly curved, 3-septate, central cells brown, end cells subhyaline, smooth-walled, without appendages or sheath. Asexual morph: Undetermined. Hyde

Type species - Longivarius aquatorbae (Boonyuen \& Sri-indr.) W. Dong, H. Zhang \& K.D.

Notes - Annulatascus aquatorbae was collected from submerged wood test block of Erythrophleum teysmannii in Thailand (Boonyuen et al. 2012). It was placed in Annulatascus based on its cylindrical asci with a relatively large, refractive apical ring and 3-septate ascospores (Boonyuen et al. 2012). However, A. aquatorbae is distinctive by unevenly colored ascospores with brown central cells and subhyaline end cells, contrasting with the hyaline ascospores of other Annulatascus species, including our three new species. In addition, A. aquatorbae forms a separated clade from Annulatascus species in our updated phylogenetic tree (Fig. 1), which corroborates other studies (Luo et al. 2015, 2019, Hyde et al. 2018, 2020). Annulatascus aquatorbae has been missing for almost 20 years since it was first collected in Thailand in 2003 
(Boonyuen et al. 2012). In order to widen the taxonomic study of Annulatascaceae, we establish a new genus Longivarius to accommodate A. aquatorbae based on distinct morphology and phylogenetic analyses.

The unevenly colored ascospores are key generic features of several genera, such as Ascitendus (Annulatascaceae) (Campbell \& Shearer 2004), Byssothecium (Massarinaceae) (Pem et al. 2019, Dong et al. 2020b) and Savoryella (Savoryellaceae) (Dayarathne et al. 2019). Longivarius is related to Ascitendus in Annulatascaceae, but they are in two distinct clades (Fig. 1). Longivarius is similar to Ascitendus in having dark ascomata with a prominent neck, cylindrical asci with a distinct apical ring, and 3-septate, fusiform ascospores. However, the asci of Longivarius have a wedge-shaped apical ring, while they are cylindrical to flaring in Ascitendus. In addition, the ascospores of Longivarius have darker central cells and paler end cells. This character is also described in Ascitendus, but not as obviously as in Longivarius. Phylogenetic analysis supports them to be different genera (Fig. 1). Although Longivarius has a weak relationship with Annulatascaceae members (Fig. 1), it is temporarily placed in Annulatascaceae based on current phylogenetic analysis.

Longivarius aquatorbae (Boonyuen \& Sri-indr.) W. Dong, H. Zhang \& K.D. Hyde, comb. nov.

Index Fungorum number: IF558026; Facesoffungi number: FoF 09547

Basionym - Annulatascus aquatorbae Boonyuen \& Sri-indr. [as 'aquatorba'], Mycologia 104(3): 752 (2012)

Holotype - BBH 29936

Known distribution (based on molecular data) - Thailand

Known habitat (based on molecular data) - freshwater

For description of this fungus see Boonyuen et al. (2012)

Atractosporales H. Zhang, K.D. Hyde \& Maharachch., Fungal Diversity 85: 88 (2017)

Type family - Atractosporaceae H. Zhang, K.D. Hyde \& Maharachch.

Notes - Atractosporales was introduced to accomodate three families, i.e. Atractosporaceae, Conlariaceae and Pseudoproboscisporaceae, based on morphology and multigene analyses (Zhang et al. 2017). Atractosporaceae and Pseudoproboscisporaceae are comparable as ascomata in both families are often parallel or oblique to the host substrate, while the ascomata in Conlariaceae have an upright neck (Ferrer et al. 2012, Liu et al. 2012, Réblová et al. 2016, Zhang et al. 2017). With more samples populated in the phylogenetic analyses, three families did not form a monophyletic clade and had relationships with other families, Cancellidiaceae and Junewangiaceae (Luo et al. 2019, Hyde et al. 2020). Luo et al. (2019) therefore excluded Conlariaceae and Pseudoproboscisporaceae to the order and referred them in Diaporthomycetidae families incertae sedis. Hyde et al. (2021) established a new order Conlariales to accommodate Conlariaceae based on a divergence time study, and retain Pseudoproboscisporaceae in Diaporthomycetidae families incertae sedis. Our phylogenetic analysis show that Conlariales clusters distantly from Atractosporaceae and Pseudoproboscisporaceae, and has relationship with Xenospadicoidales, while Pseudoproboscisporaceae clusters with Junewangiaceae (Fig. 1).

Atractosporaceae H. Zhang, K.D. Hyde \& Maharachch., Fungal Diversity 85: 88 (2017)

Type genus - Atractospora Réblová \& J. Fourn.

Notes - Atractosporaceae was established for two freshwater genera Atractospora and Rubellisphaeria, which have pigmented ascomata with a lateral neck and hyaline ascospores (Zhang et al. 2017). The divergence time study also supported it as a distinct family (Hongsanan et al. 2017, Hyde et al. 2017, Zhang et al. 2017). The ascomata with a lateral neck which are upright or oblique to the host substrate are the common characteristics in several annulatascaceae-like taxa in different families, e.g. Diluviicola (Pseudoproboscisporaceae), Fusoidigranularius (Annulatascaceae), Neodiluviicola (Pseudoproboscisporaceae) and Obliquiminima (Cancellidiaceae). The asexual morph of Atractosporaceae is undetermined. 
Atractospora Réblová \& J. Fourn., Mycol. Progr. 15(no. 21): 8 (2016)

Type species - Atractospora reticulata Réblová \& J. Fourn.

Notes - Atractospora was introduced by Réblová et al. (2016) to accommodate three new species and one new combination which were transferred from Aquaticola. Atractospora differs from Aquaticola by its ascomata lying horizontally on the substrate and fusiform ascospores (Ho et al. 1999b, Tsui et al. 2003, Réblová et al. 2016). All six Atractospora species, including our new collection of A. ellipsoidea, were collected from freshwater habitats (Ho et al. 1999b, Réblová et al. 2016, Zhang et al. 2017, Luo et al. 2019).

Atractospora ellipsoidea (W.H. Ho, C.K.M. Tsui, Hodgkiss \& K.D. Hyde) Réblová \& J. Fourn., Mycol. Progr. 15(no. 21): 13 (2016)

Fig. 5

Facesoffungi number: FoF 09548

Saprobic on submerged wood in freshwater. Sexual morph: Ascomata 90-120 $\mu \mathrm{m}$ high, 120 $140 \mu \mathrm{m}$ diam., scattered, superficial, ellipsoidal, dark brown to black, lying horizontally on the substrate, coriaceous, ostiolate, with a lateral neck. Necks 40-60 $\mu \mathrm{m}$ long, black, cylindrical, curving upwards, comprising single layer of brown to dark brown cells of textura angularis. Peridium 8.5-12 $\mu \mathrm{m}$ thick at upper part, comprising 5-7 layers of brown to dark brown, thinwalled, compressed cells of textura angularis; $35-40 \mu \mathrm{m}$ thick near the base where below the neck, comprising 9-11 layers of brown to dark brown, thick-walled, large cells of textura angularis. Paraphyses $5 \mu \mathrm{m}$ diam., sparse, hypha-like, uneven subcylindrical, septate, constricted at septa, unbranched, hyaline. Asci 75-120 × 10-14 $\mu \mathrm{m}(\bar{x}=98 \times 11.5 \mu \mathrm{m}, \mathrm{n}=10), 8$-spored, unitunicate, subcylindrical, wider in the middle part, apex slightly truncate, pedicellate, with a small, refractive apical ring, 2.7-3 $\times 2.3-2.5 \mu \mathrm{m}$. Ascospores 16-19 $\times 6-7.5 \mu \mathrm{m}(\bar{x}=17.8 \times 6.5 \mu \mathrm{m}, \mathrm{n}=10)$, overlapping uniseriate, or partially biseriate in the middle part, hyaline when young, becoming pale brown when mature, ellipsoidal, rounded or slightly acute at both ends, straight or curved, two apices occasionally reverse bending, aseptate when young, 1-septate when mature, not constricted at septum, guttulate, thin-walled, smooth, without a mucilaginous sheath. Asexual morph: Undetermined.

Culture characteristics - On PDA, colony circular, reaching $30 \mathrm{~mm}$ in 65 days at $25^{\circ} \mathrm{C}$, graydark brown from above, dark brown to black from below, surface rough, dry, with sparse mycelium, flat, entire at edge.

Material examined - China, Yunnan Province, Pingbian City, on submerged wood in a stream, 20 September 2017, W. Dong, WF18A (MFLU 18-1182), living culture KUMCC 18-0051; ibid., HKAS 101702.

Notes - Although the type material of Aquaticola ellipsoidea was unavailable for morphological examination, Réblová et al. (2016) transferred A. ellipsoidea to Atractospora based on original description (Ho et al. 1999b) and two reference sequences, AY590290 and AY316356 (Raja et al. 2003, Campbell \& Shearer 2004). We name our new collection KUMCC 18-0051 as A. ellipsoidea considering its very similar morphological characteristics with the holotype (Ho et al. 1999b), except for septa of the ascospores. We observed 1-septate ascospores when mature, while they were aseptate in the holotype (Ho et al. 1999b). This is probably because the holotype was examined when young or large guttules obscured the septa (Réblová et al. 2016). In this study, we confirm A. ellipsoidea in Atractospora with morphological and molecular data derived from our new collection KUMCC 18-0051.

KUMCC 18-0051 forms a strongly supported clade with two strains of Atractospora ellipsoidea (A411-3 and R008) (Fig. 1). We found 16 nucleotide differences in LSU sequence data between A411-3 and R008 (LSU: AY316356, AY590290), which phylogenetically appears to be different species. Unfortunately, no other sequence data can be compared for A411-3 and R008. Morphological characteristics for the two strains are unavailable (Raja et al. 2003, Campbell \& Shearer 2004), therefore their real identities are undetermined. Nevertheless, the morphology strongly confirms our collection to be A. ellipsoidea. 

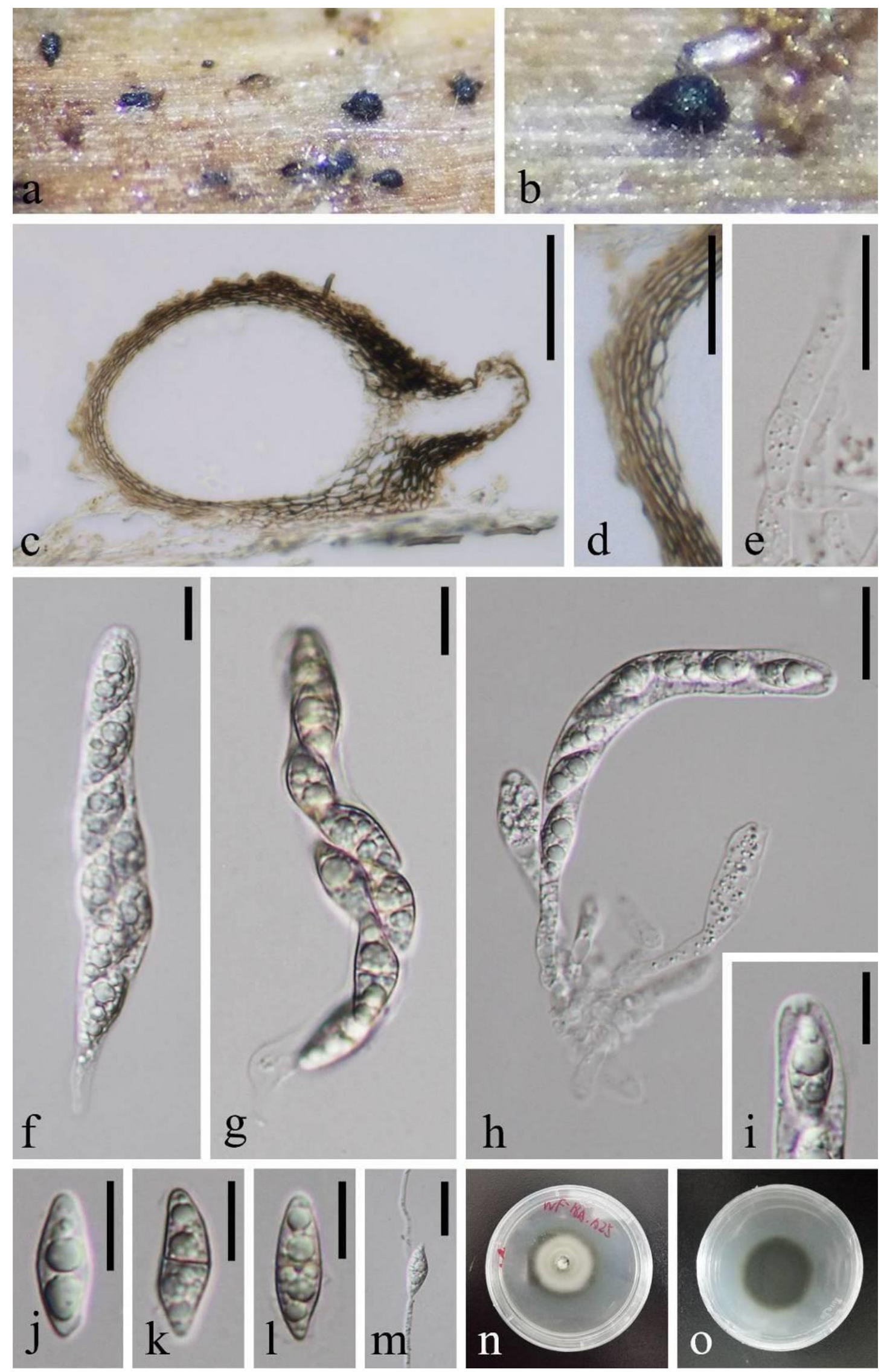

Figure 5 - Atractospora ellipsoidea (MFLU 18-1182). a, b Ascomata on host substrate. c Vertical section of ascoma. d Structure of peridium. e Paraphyses. $\mathrm{f}-\mathrm{h}$ Unitunicate asci. i Apical ring. j-l Ascospores. m Germinated ascospore. n, o Colony on PDA (left-front, right-reverse). Scale bars: $\mathrm{c}=50 \mu \mathrm{m}, \mathrm{d}, \mathrm{e}, \mathrm{h}, \mathrm{m}=20 \mu \mathrm{m}, \mathrm{f}, \mathrm{g}, \mathrm{i}-\mathrm{l}=10 \mu \mathrm{m}$. 
Cancellidiales K.D. Hyde \& Hongsanan, Fungal Diversity: 10.1007/s13225-021-00469-7 (2021)

Type family - Cancellidiaceae K.D. Hyde \& Hongsanan

Notes - Cancellidiales was introduced to accommodate a single family Cancellidiaceae with a genus Cancellidium. The establishment of Cancellidiales was supported by divergence time study that the stem age was estimated as 137 MYA which fell in the range of an order (Hyde et al. 2021).

Cancellidiaceae K.D. Hyde \& Hongsanan, Fungal Diversity: 10.1007/s13225-021-00469-7 (2021)

Type genus - Cancellidium Tubaki

Notes - Cancellidiaceae was established for an asexual genus Cancellidium based on a divergence time study (Hyde et al. 2021). In this study, we propose a new genus Obliquiminima in the family, which is the first sexual morph linked by molecular data and morphologically similar to Annulatascaceae species.

Cancellidium Tubaki, Trans. Mycol. Soc. Japan 16(4): 357 (1975)

Type species - Cancellidium applanatum Tubaki

Notes - Cancellidium is characterized by shiny, obovate to obcordate conidia which are composed of parallel rows of cells encapsulating strings of monilioid cells (Tubaki 1975, Yeung et al. 2006). Since the type species $C$. applanatum was sequenced (Pratibha et al. 2014, Zelski et al. 2014), more species were added to the genus and the placement of Cancellidium was discussed accordingly. Cancellidium was referred to Sordariomycetidae genera incertae sedis (Hyde et al. 2020), later was classified in a newly established family Cancellidiaceae based on a divergence time study (Hyde et al. 2021). The sexual morph of Cancellidium is unknown. We introduce a new asexual species in the genus and provide several new collections of $C$. atrobrunneum and $C$. griseonigrum.

Cancellidium atrobrunneum D.F. Bao, Z.L. Luo, K.D. Hyde \& H.Y. Su, Fungal Diversity: 10.1007/s13225-021-00469-7 (2021)

Fig. 6

Saprobic on submerged wood in freshwater. Sexual morph: Undetermined. Asexual morph: Hyphomycetous. Colonies effuse, gregarious, dark brown to black, olivaceous, shiny. Mycelium partly immersed, partly superficial on substratum, consisting of septate, thin-walled, hyaline hyphae. Conidiophores absent. Conidiogenous cells 17-20 ×3-4.5 $\mu \mathrm{m}(\bar{x}=18 \times 4 \mu \mathrm{m}, \mathrm{n}=5)$, holoblastic, monoblastic, integrated, determinate, terminal, subcylindrical, pale brown to hyaline, thick-walled, smooth. Conidia 120-150 × 70-100 $\mu \mathrm{m}(\bar{x}=137 \times 85 \mu \mathrm{m}, \mathrm{n}=10)$, solitary, dry, thin-walled, smooth-walled, ovoid, ellipsoidal, or irregular, with rounded ends, dictyoseptate, olivaceous brown to dark brown, composed of several parallel, adherent rows radiating from base. Rows 3-6.5 $\mu \mathrm{m}$ wide, septate, containing rectangular and moniliform cells.

Culture characteristics - On PDA, colony irregular, reaching $15 \mathrm{~mm}$ in 30 days at $25^{\circ} \mathrm{C}$, grey from above, dark from below, surface rough, dry, with dense mycelium, raised, curled at edge.

Material examined - Thailand, Chiang Mai Province, on submerged wood in a stream, 1 September 2017, X.D. Yu, 3A (MFLU 17-1720), living culture MFLUCC 17-2361.

Notes - Cancellidium atrobrunneum was collected from a submerged wood in a freshwater stream in Thailand (Hyde et al. 2021). Our new collection MFLUCC 17-2361 has very similar morphological characteristics with $C$. atrobrunneum in all aspects. Multigene analysis supports them to be the same species (Fig. 1).

Cancellidium griseonigrum J. Yang \& K.D. Hyde, Fungal Diversity: 10.1007/s13225-021-00469-7 (2021)

Saprobic on submerged wood in freshwater. Sexual morph: Undetermined. Asexual morph: Hyphomycetous. Colonies effuse, gregarious, black, shiny. Mycelium partly immersed, partly superficial on substratum, consisting of septate, thin-walled, hyaline hyphae. Conidiophores absent. Conidiogenous cells holoblastic, monoblastic. Conidia 205-270 $\times 115-150 \mu \mathrm{m}(\bar{x}=245 \times 133$ $\mu \mathrm{m}, \mathrm{n}=10$ ), solitary, dry, thin-walled, smooth-walled, broadly fusiform, ellipsoidal, with tapering 
ends, olivaceous brown to black, easily cracked when mounted in water, composed of many parallel adherent, rows. Rows 3-6.5 $\mu \mathrm{m}$ wide, septate, constricted at septa, brown to olivaceous brown, radiate from conidial base.

Culture characteristics - On PDA, colony irregular, reaching $15 \mathrm{~mm}$ in 33 days at $25^{\circ} \mathrm{C}$, gray brown from above, dark brown from below, surface rough, dry, with dense mycelium, raised, curled at edge.

Material examined - Thailand, Songkhla Province, on submerged wood in a stream, 10 May 2018, W. Dong, hat147 (MFLU 18-1537), living culture MFLUCC 18-1236; ibid., HKAS 105010, living culture KUMCC 19-0026.

Notes - Cancellidium griseonigrum was collected from submerged wood in a freshwater stream in Thailand (Hyde et al. 2021). Our new collection MFLUCC 18-1236 has overlapping conidial size and very similar morphology with the holotype of $C$. griseonigrum. A nucleotide comparison and multigene analysis indicate our collection to be $C$. griseonigrum (Fig. 1).

Cancellidium thailandense W. Dong, H. Zhang \& K.D. Hyde, sp. nov.

Fig. 8

Index Fungorum number: IF558034; Facesoffungi number: FoF 09556

Etymology - in reference to Thailand, where the holotype was collected

Holotype - MFLU 18-1510

Saprobic on submerged wood in freshwater. Sexual morph: Undetermined. Asexual morph: Hyphomycetous. Colonies effuse, gregarious, black, shiny. Mycelium partly immersed, partly superficial on substratum, consisting of septate, thin-walled, hyaline hyphae. Conidiophores 25-55 $\times 3.5-4 \mu \mathrm{m}(\bar{x}=40 \times 3.75 \mu \mathrm{m}, \mathrm{n}=5)$, micronematous, mononematous, subcylindrical, flexuous, 0-2-septate, slightly constricted at septa, unbranched, pale brown, thick-walled, smooth. Conidiogenous cells 15-18 × 3.5-4.7 $\mu \mathrm{m}(\bar{x}=16.5 \times 4 \mu \mathrm{m}, \mathrm{n}=5)$, holoblastic, monoblastic, integrated, determinate, terminal, subcylindrical, pale brown, thick-walled, smooth. Conidia 78$105 \times 60-100 \mu \mathrm{m}(\bar{x}=90.5 \times 85 \mu \mathrm{m}, \mathrm{n}=10)$, solitary, dry, thin-walled, smooth-walled, subglobose, ellipsoidal, dictyoseptate, olivaceous, easily cracked when mounted in water, composed of many parallel adherent, rows. Rows 3-6 $\mu \mathrm{m}$ wide, septate, constricted at septa, olivaceous, radiate from conidial base.

Culture characteristics - On PDA, colony irregular, reaching $8 \mathrm{~mm}$ in 30 days at $25^{\circ} \mathrm{C}$, black from above and below, surface rough, dry, with dense mycelium, raised, undulate at edge.

Material examined - Thailand, Songkhla Province, on submerged wood in a stream, 10 May 2018, W. Dong, 20180511 (MFLU 18-1510, holotype), ex-type living culture MFLUCC 18-1142; ibid., HKAS 104995, isotype, ex-isotype living culture KUMCC 19-0012.

Notes - Cancellidium thailandense is similar to other species in the genus in having monoblastic, terminal conidiogenous cells, and dictyoseptate conidia comprising of many parallel adherent rows. However, C. thailandense differs by subglobose, olivaceous conidia (Tubaki 1975, Yeung et al. 2006, Pratibha et al. 2014, Zelski et al. 2014, Hyde et al. 2021). Multigene analysis supports it to be a new species in the genus (Fig. 1).

Obliquiminima W. Dong, H. Zhang \& K.D. Hyde, gen. nov.

Index Fungorum number: IF558035; Facesoffungi number: FoF 09557

Etymology - in reference to its neck growing oblique to the host substrate and small ascomata

Saprobic on submerged wood in freshwater. Sexual morph: Ascomata tiny, scattered, superficial, ellipsoidal to subglobose, black, coriaceous, ostiolate, with a lateral neck. Necks short, black, cylindrical, oblique to the host substrate. Peridium comprising several layers of dark brown to black, thick-walled, compressed cells of textura angularis. Paraphyses tapering towards the apex, dense, hypha-like, septate, unbranched, hyaline. Asci 8-spored, unitunicate, narrowly obclavate, slightly truncate at apex, sessile, with a small, refractive apical ring. Ascospores uni- to bi-seriate, oval, narrowly ellipsoidal, straight, aseptate, guttulate, hyaline, thin-walled, smooth, with a thin gelatinous sheath. Asexual morph: Undetermined. 

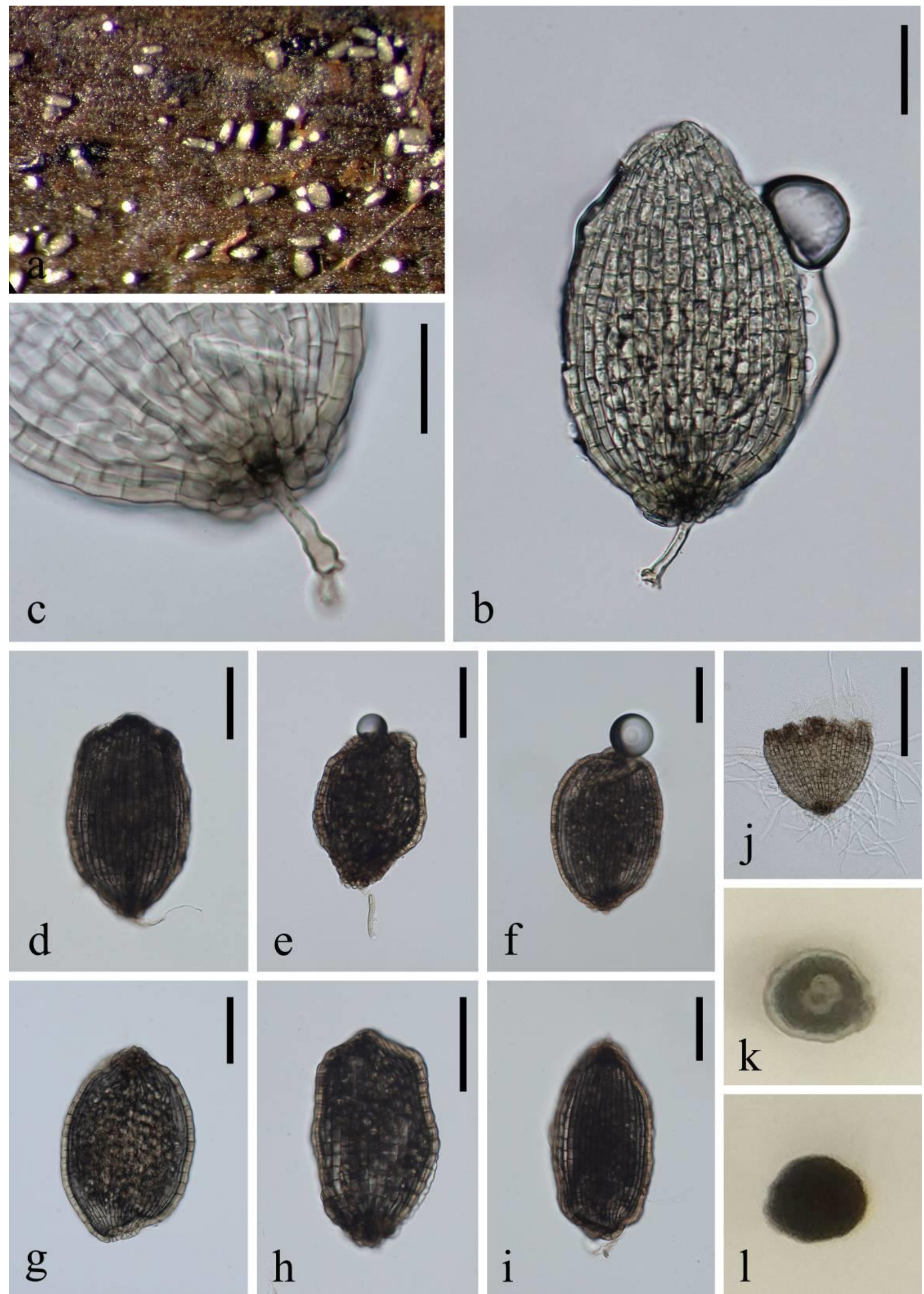

Figure 6 - Cancellidium atrobrunneum (MFLU 17-1720), a Colonies on submerged wood. b, c Conidia with conidiogenous cells. $d-i$ Conidia. $j$ Germinated conidium. $k, 1$ Colony on PDA (up-front, down-reverse). Scale bars: $b=30 \mu \mathrm{m}, \mathrm{c}=20 \mu \mathrm{m}, \mathrm{d}-\mathrm{i}=50 \mu \mathrm{m}, \mathrm{j}=100 \mu \mathrm{m}$. 

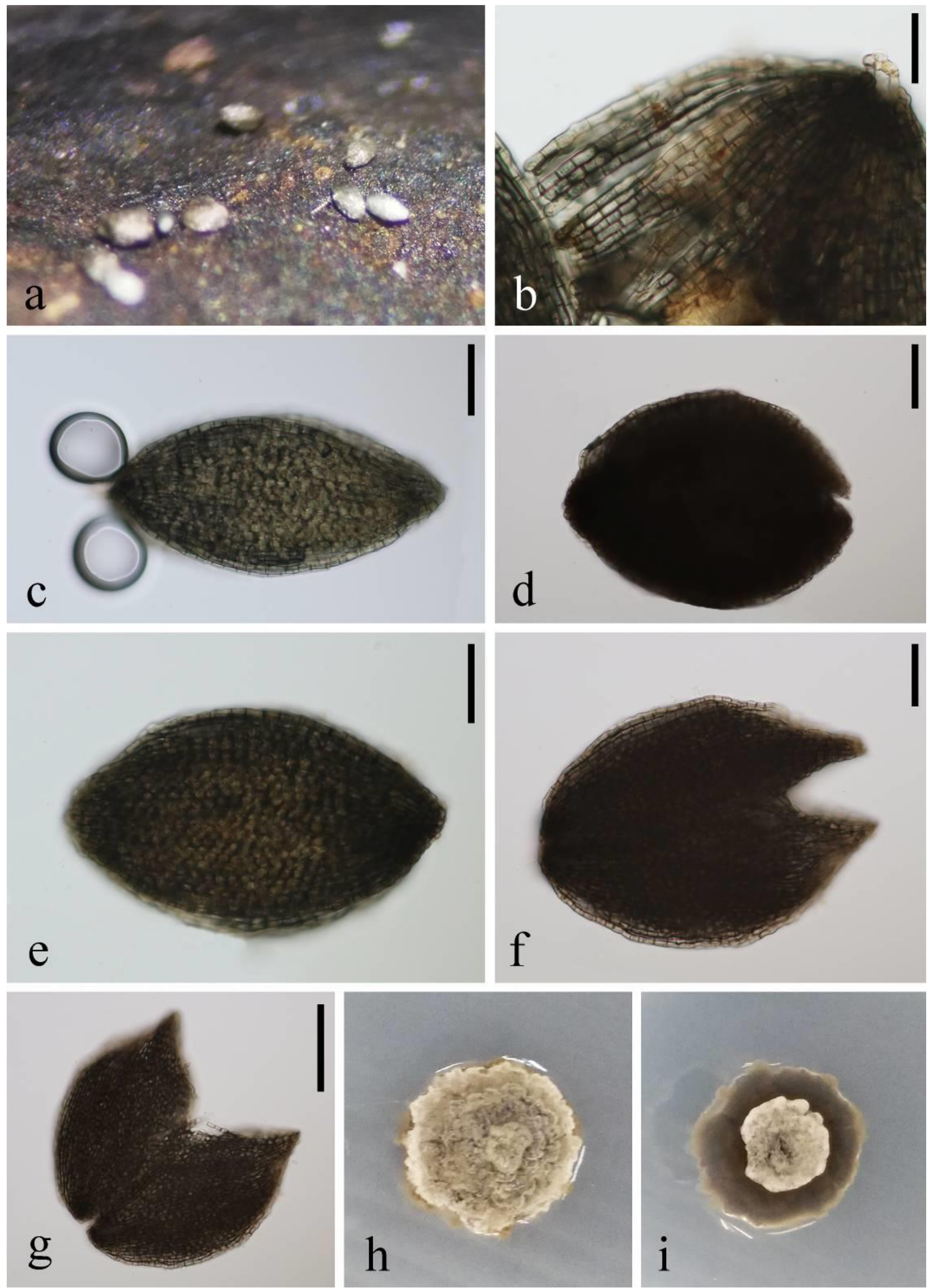

Figure 7 - Cancellidium griseonigrum (MFLU 18-1537). a Colonies on submerged wood. b-g Conidia (b note the parallel rows of cells). h, i Colony on PDA (left-front, right-reverse). Scale bars: $\mathrm{b}=30 \mu \mathrm{m}, \mathrm{c}-\mathrm{f}=50 \mu \mathrm{m}, \mathrm{g}=100 \mu \mathrm{m}$. 

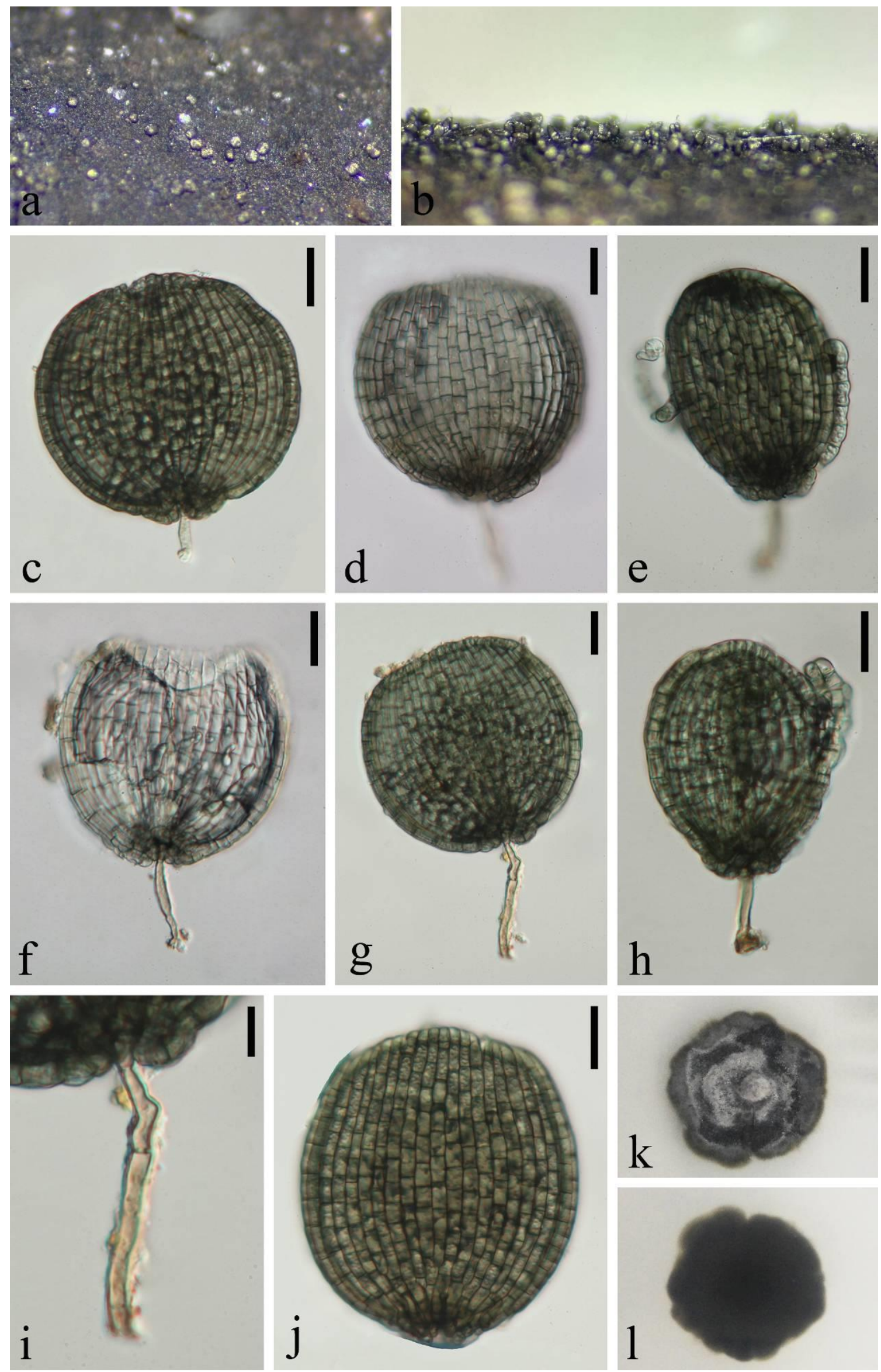

Figure 8 - Cancellidium thailandense (MFLU 18-1510, holotype). a, b Colonies on submerged wood. c-e, j Conidia. f-i Conidiophores with conidia. k, 1 Colony on PDA (up-front, downreverse). Scale bars: $\mathrm{c}-\mathrm{h}, \mathrm{j}=20 \mu \mathrm{m}, \mathrm{i}=10 \mu \mathrm{m}$. 
Type species - Obliquiminima hyalina W. Dong, H. Zhang \& K.D. Hyde

Notes - Obliquiminima forms a sister clade with a hyphomycetous genus Cancellidium in Cancellidiaceae with high bootstrap support (Fig. 1). Cancellidium is characterized by dictyosporous conidia arising from small conidiophores (Tubaki 1975). No sexual morphs are reported in Cancellidium, thus the morphology between Cancellidium and Obliquiminima cannot be compared. Our multigene analysis supports Obliquiminima to be a new genus in Cancellidiaceae (Fig. 1).

Obliquiminima can be compared to an annulatascaceae-like genus Ayria in having ellipsoidal, aseptate, hyaline, finely guttulate ascospores (Fryar \& Hyde 2004). However, Obliquiminima differs in having superficial ascomata, with a lateral neck that oblique to the host substrate, narrowly obclavate asci with a refractive apical ring. In contrast, Ayria has immersed ascomata that become superficial at maturity, clavate asci without an apical ring (Fryar \& Hyde 2004). Ayria also has a neck, but which was not described in detail for two species, A. appendiculata and A. nubispora (Fryar \& Hyde 2004, Raja et al. 2009). Ayria is placed in Annulatascaceae based on morphology, but it lacks molecular data (Hyde et al. 2020). Sequence data for Ayria are needed to infer the phylogenetic relationships between Ayria and Obliquiminima.

Obliquiminima hyalina W. Dong, H. Zhang \& K.D. Hyde, sp. nov.

Fig. 9

Index Fungorum number: IF558036; Facesoffungi number: FoF 09557

Etymology - in reference to hyaline ascospores of the fungus

Holotype - MFLU 18-1521

Saprobic on submerged wood in freshwater. Sexual morph: Ascomata 130-150 $\mu \mathrm{m}$ high, 140-160 $\mu \mathrm{m}$ diam., scattered, superficial, ellipsoidal to subglobose, black, coriaceous, ostiolate, with a lateral neck. Necks short, black, cylindrical, oblique to the substrate surface. Peridium 10-15 $\mu \mathrm{m}$ thick, comprising 5-7 layers of dark brown to black, thick-walled, compressed cells of textura angularis. Paraphyses up to $15 \mu \mathrm{m}$ diam. at the base, tapering towards the apex, dense, hypha-like, septate, constricted at septa, unbranched, hyaline. Asci 150-215 × 16-20.5 $\mu \mathrm{m}(\bar{x}=178 \times 18.5 \mu \mathrm{m}$, $\mathrm{n}=20$ ), 8-spored, unitunicate, narrowly obclavate, slightly truncate at apex, sessile, with a small, refractive, discoid, apical ring, $2.4 \times 4.2 \mu \mathrm{m}$. Ascospores 30.5-37.5 $\times 9-12.5 \mu \mathrm{m}(\bar{x}=34.5 \times 10.5$ $\mu \mathrm{m}, \mathrm{n}=10$ ), uni- to bi-seriate, oval, narrowly ellipsoidal, straight, aseptate, 3 -septate when germinated, finely guttulate, hyaline, thin-walled, smooth, with a thin gelatinous sheath. Asexual morph: Undetermined.

Culture characteristics - On PDA, colony circular, reaching $20 \mathrm{~mm}$ in 47 days at $25^{\circ} \mathrm{C}$, gray brown from above, dark brown from below, surface rough, dry, with dense mycelium, raised, entire at edge.

Material examined - Thailand, Songkhla Province, on submerged wood in a stream, 10 May 2018, W. Dong, hat142 (MFLU 18-1521, holotype), ex-type living culture MFLUCC 18-1235; ibid., HKAS 105009, isotype, ex-isotype living culture KUMCC 19-0025; chestnut hill, on submerged wood in a stream, 10 May 2018, W. Dong, hat459 (MFLU 18-1529), living culture MFLUCC 18-1401; ibid., HKAS 105046, living culture KUMCC 19-0065.

Conlariales K.D. Hyde \& Hongsanan, Fungal Diversity: 10.1007/s13225-021-00469-7 (2021)

Type family - Conlariaceae H. Zhang, K.D. Hyde \& Maharachch

Notes - Conlariales was introduced to accommodate Conlariaceae which was previously placed in Atractosporales (Hyde et al. 2021). The divergence time estimated the stem age of Conlariales was 138 MYA, which fell in the range of an order (Hyde et al. 2021).

Conlariaceae H. Zhang, K.D. Hyde \& Maharachch., Fungal Diversity 85: 90 (2017)

Type genus - Conlarium F. Liu \& L. Cai

Notes - Conlariaceae was established to accommodate a single holomorphic genus Conlarium (Zhang et al. 2017). Luo et al. (2019) included another sexual genus Riomyces in the family based on multigene analysis. In our phylogenetic analysis (Fig. 1), Riomyces clusters within 
Conlarium with good bootstrap support. However, the two genera have entirely different characteristics. Conlarium has a long neck of ascomata, cylindrical asci with a large apical ring and fusiform ascospores, while Riomyces has a short neck of ascomata, asci without an apical ring, and broadly ellipsoidal-fusiform ascospores with an irregular, expanding sheath (Ferrer et al. 2012, Liu et al. 2012). The asexual morph of Conlarium has muriform, brown and irregular-shaped conidia, while the asexual morph of Riomyces is undetermined. To clarify the relationships between Conlarium and Riomyces, more collections are needed for these two genera. Conlariaceae was placed in Atractosporales based on limited data (Zhang et al. 2017), and later was shown to be phylogenetically distant from the type family Atractosporaceae in Luo et al. (2019). Hyde et al. (2021) established a new order Conlariales to accommodate this family based on a divergence time study.

Conlarium F. Liu \& L. Cai, Mycologia 104(5): 1180 (2012)

Type species - Conlarium dupliciascosporum F. Liu \& L. Cai

Notes - Conlarium is the only holomorphic genus in the family and characterized by dark brown to black ascomata with a long, cylindrical neck, cylindrical asci with a short pedicellate and a large apical ring, fusiform, hyaline ascospores, with or without globose or papillary appendages, and muriform, irregular-shaped conidia (Liu et al. 2012). Conlarium comprises terrestrial and freshwater species described from natural substrate and artificial culture (Liu et al. 2012, Zhang et al. 2017, Phookamsak et al. 2019, Xie et al. 2019). We introduce a new asexual species in Conlarium, which is collected from submerged wood in freshwater in Thailand. A new collection of $C$. aquaticum from China is also described and illustrated.

Conlarium aquaticum W. Dong, H. Zhang \& K.D. Hyde, Fungal Diversity 85: 92 (2017) Fig. 10 Saprobic on submerged wood in freshwater. Sexual morph: Undetermined. Asexual morph: Hyphomycetous. Colonies sporodochial, punctiform, gregarious, raised, black. Mycelium partly immersed, partly superficial on substratum, consisting of septate, thin-walled, hyaline hyphae. Conidiophores absent or reduced to conidiogenous cells. Conidiogenous cells up to $22 \mu \mathrm{m}$ long, holoblastic, monoblastic, integrated, determinate, terminal, subcylindrical, hyaline, smooth. Conidia 22.5-52 $\times 18-31 \mu \mathrm{m}(\bar{x}=33 \times 24 \mu \mathrm{m}, \mathrm{n}=25)$, acrogenous, solitary, dry, thin-walled, smooth-walled, ellipsoidal, clavate, obovoid, subglobose, or irregular-shaped, muriform, multiseptate, slightly constricted at septa, dark brown, olive brown on the surface, with a hyaline or pale brown, cuneiform base.

Culture characteristics - On PDA, colony circular, reaching $10 \mathrm{~mm}$ in 27 days at $25^{\circ} \mathrm{C}$, graybrown from above, black from below, surface rough, dry, with sparse mycelium, raised, entire at edge.

Material examined - China, Yunnan Province, Dehong City, on submerged wood in a stream, 25 November 2017, G.N. Wang, H26A (MFLU 18-1181), living culture MFLUCC 18-1417; ibid., HKAS 101744, living culture KUMCC 18-0096.

Notes - Conlarium aquaticum was initially collected from a freshwater stream in Thailand (Zhang et al. 2017). Although our new collection has smaller conidia than the holotype (22.5-52 $\times$ 18-31 $\mu \mathrm{m}$ vs. $45-70 \times 20-57 \mu \mathrm{m})$, phylogenetic analysis and single gene comparison support them to be the same species (Fig. 1). This is a new geographical record of C. aquaticum in China.

Conlarium subglobosum X.D. Yu, W. Dong \& H. Zhang, sp. nov.

Fig. 11

Index Fungorum number: IF558037; Facesoffungi number: FoF 09558

Etymology - in reference to subglobose conidia

Holotype - MFLU 17-1728

Saprobic on submerged wood in freshwater. Sexual morph: Undetermined. Asexual morph: Hyphomycetous. Colonies sporodochial, punctiform, gregarious, raised, brown. Mycelium partly immersed, partly superficial on substratum, consisting of septate, thin-walled, hyaline hyphae. Conidiophores absent or reduced to conidiogenous cells. Conidiogenous cells holoblastic, 
integrated, determinate. Conidia 14.5-24 $\mu \mathrm{m}$ diam. $(\bar{x}=18.5 \mu \mathrm{m}, \mathrm{n}=40)$, acrogenous, solitary, dry, thin-walled, smooth, subglobose, dictyoseptate, slightly constricted at septa, brown to dark brown, with a protruding, cuneiform, pale brown base, with a small, sub-rounded, dark brown ornamentation on the surface of each cell.
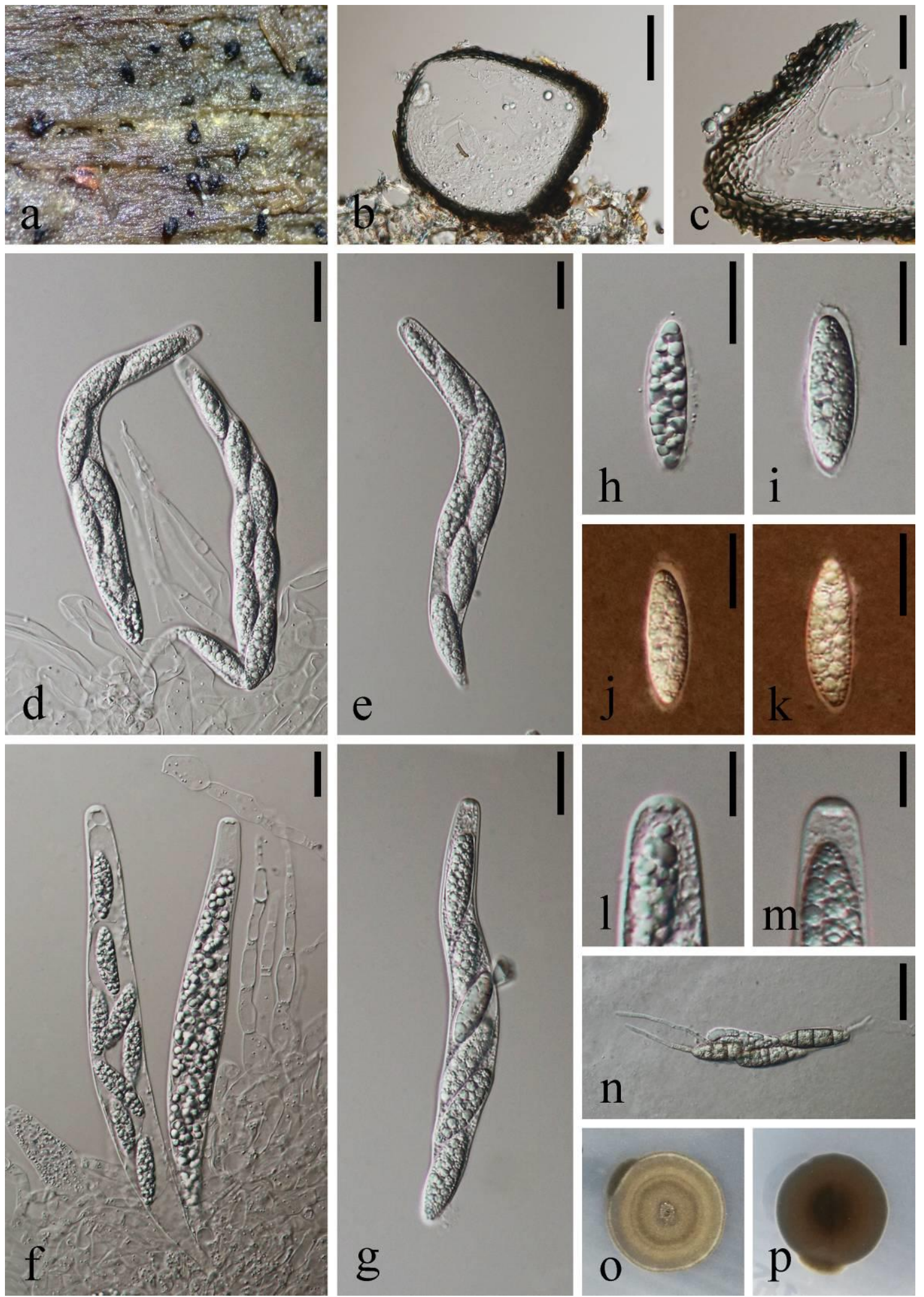

Figure 9 - Obliquiminima hyalina (MFLU 18-1521, holotype). a Ascomata on host substrate. b Vertical section of ascoma. c Structure of peridium. d-g Unitunicate asci. h, i Ascospores in water. j, k Ascospores in Indian Ink. 1, m Apical rings. n Germinated ascospores. o, p Colony on 
PDA (left-front, right-reverse). Scale bars: $\mathrm{b}=50 \mu \mathrm{m}, \mathrm{c}, \mathrm{e}, \mathrm{f}, \mathrm{h}-\mathrm{k}=20 \mu \mathrm{m}, \mathrm{d}, \mathrm{g}, \mathrm{n}=30 \mu \mathrm{m}$, $1, \mathrm{~m}=10 \mu \mathrm{m}$.
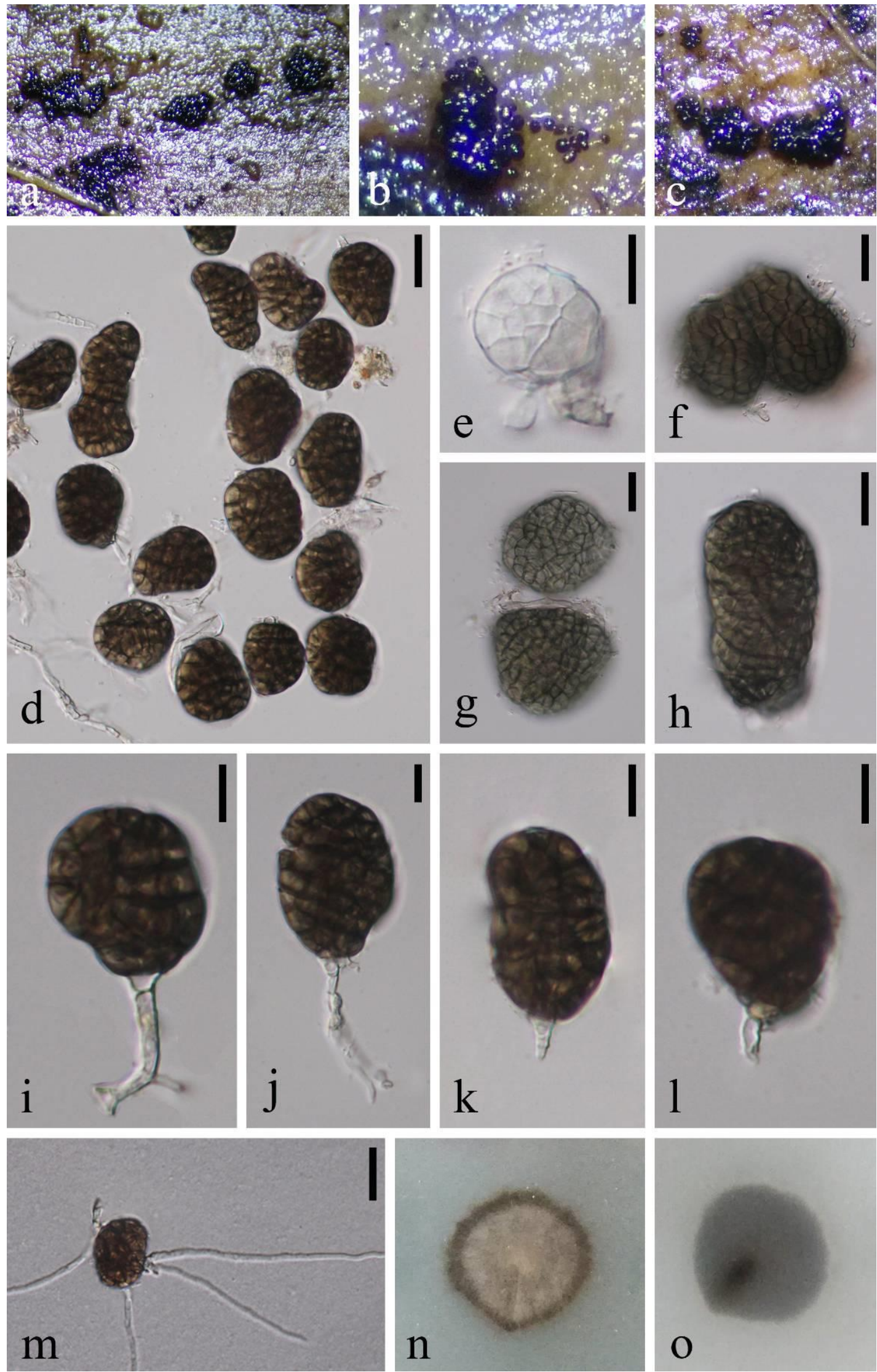

Figure 10 - Conlarium aquaticum (MFLU 18-1181). a-c Colonies on submerged wood. $\mathrm{d}-\mathrm{h}$ Conidia (e immature conidium; $\mathrm{f}-\mathrm{h}$ note the muriform surface of conidia). $\mathrm{i}-\mathrm{l}$ Conidia with 
conidiogenous cells. m Germinated conidium. n, o Colony on PDA (left-front, right-reverse). Scale bars: $\mathrm{d}, \mathrm{f}-\mathrm{h}, \mathrm{m}=20 \mu \mathrm{m}, \mathrm{e}, \mathrm{i}-\mathrm{l}=10 \mu \mathrm{m}$.

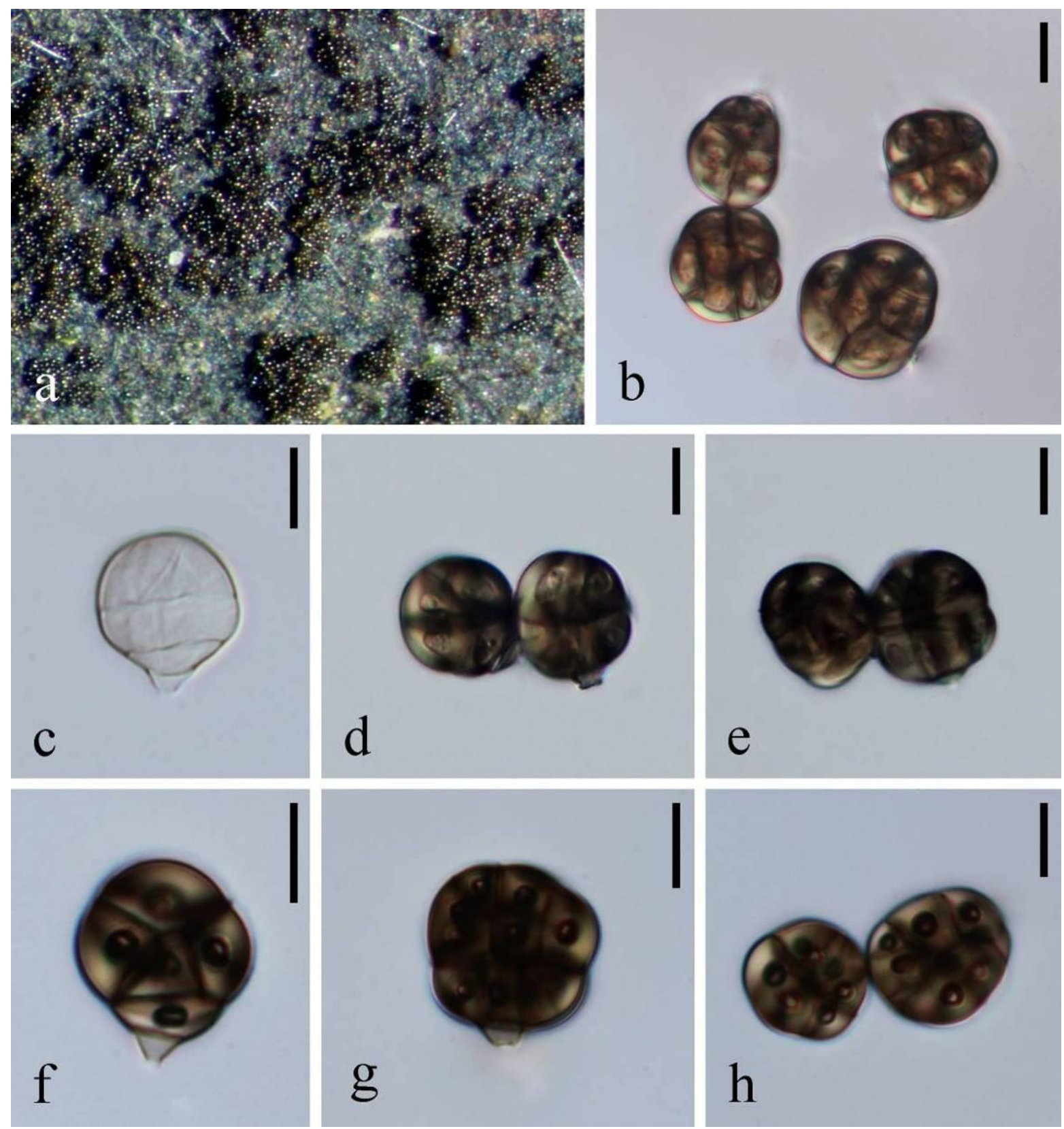

Figure 11 - Conlarium subglobosum (MFLU 17-1728, holotype). a Colonies on submerged wood. b-h Conidia. Scale bars: $\mathrm{b}-\mathrm{h}=10 \mu \mathrm{m}$.

Material examined - Thailand, Chiang Mai Province, Mushroom Research Centre, on submerged wood in a stream, 1 September 2017, X.D. Yu, 17A (MFLU 17-1728, holotype).

Notes - Our new collection MFLU 17-1728 forms a basal branch to other Conlarium species and the genus Riomyces with high bootstrap support (Fig. 1). MFLU 17-1728 must be placed in Conlarium because of its typical conidia of Conlarium. MFLU 17-1728 is similar to $C$. thailandense in having a dark brown ornamentation on the surface of each cell (Phookamsak et al. 2019), but the conidial shape and size and molecular evidence support them to be different species (Fig. 1). The new collection also resembles a phylogenetically unrelated species Junewangia thailandica in conidial characteristics, but differs in having punctiform colonies and lacking conidiophores. We therefore identify MFLU $17-1728$ as a new species in Conlarium, namely as $C$. subglobosum. We sequenced from the conidia as the culture was contaminated. 
Distoseptisporales Z.L. Luo, K.D. Hyde \& H.Y. Su, Fungal Diversity 99: 482 (2019)

Type family - Distoseptisporaceae K.D. Hyde \& McKenzie

Notes - Distoseptisporales was introduced to accommodate a single family Distoseptisporaceae and one genus Aquapteridospora based on morphology and multigene analysis (Luo et al. 2019). Hyde et al. (2021) raised Aquapteridospora as a new family Aquapteridosporaceae regarding to their divergence time study (110 MYA). Hyde et al. (2020) mentioned that Distoseptisporales status might need revision as its divergence time was estimated as 102 MYA which fell in the range of family status (50-130 MYA), while it was 158 MYA in Hyde et al. (2021). In this study, we follow Hyde et al. (2021) and accept the order Distoseptisporales with two families Aquapteridosporaceae and Distoseptisporaceae.

Aquapteridosporaceae K.D. Hyde \& Hongsanan, Fungal Diversity: 10.1007/s13225-021-00469-7 (2021)

Type genus - Aquapteridospora J. Yang, K.D. Hyde \& Maharachch.

Notes - Aquapteridosporaceae was established to accommodate a single genus Aquapteridospora which was formerly referred to Distoseptisporales genera incertae sedis (Luo et al. 2019, Hyde et al. 2021). The divergence time for Aquapteridosporaceae has been estimated as 110 MYA, which falls in the range of a family (50-130 MYA) (Hyde et al. 2021).

Aquapteridospora J. Yang, K.D. Hyde \& Maharachch., Cryptog. Mycol. 36(4): 474 (2015)

Type species - Aquapteridospora lignicola J. Yang, K.D. Hyde \& Maharachch.

Notes - Aquapteridospora is characterized by polyblastic conidiogenous cells, fusiform, 3septate, thin-walled conidia with pale to dark brown central cells and paler end cells, often with a conspicuous sheath (Yang et al. 2015). In our multigene analysis (Fig. 1), Pleurophragmium bambusinum clusters within Aquapteridospora with high bootstrap support. However, $P$. bambusinum has ellipsoidal, thick-walled, evenly coloured conidia without a sheath (Dai et al. 2017), which indicate that it does not belong in Aquapteridospora.

Pleurophragmium is an old genus that comprises over 40 epithets in Index Fungorum (2021). The sequence data of the type species P. bicolor is lacking, and Pleurophragmium was shown to be polyphyletic in Dai et al. (2017). Pleurophragmium is characterized by unbranched conidiophores, polyblastic, sympodial conidiogenous cells, and ellipsoidal to fusiform, or clavate, brown, 0-7septate conidia with pointed bases (Ellis 1971, Ma et al. 2014). Morphologically, Aquapteridospora and Pleurophragmium are not congeneric. Although $P$. bambusinum clusters within Aquapteridospora, we do not synonymize P. bambusinum under Aquapteridospora due to its unusual morphological characteristics with other Aquapteridospora species. In addition, all Aquapteridospora species were found from freshwater (Yang et al. 2015, Luo et al. 2019), while $P$. bambusinum was collected from dead culms of bamboo (Dai et al. 2017). The new collections and sequences of $P$. bambusinum and type species $P$. bicolor are needed to reappraise their placements. We introduce a new species in Aquapteridospora, which is morphologically similar to the type species A. lignicola.

Aquapteridospora aquatica X.D. Yu, W. Dong \& H. Zhang, sp. nov.

Fig. 12 Index Fungorum number: IF558031; Facesoffungi number: FoF 09552

Etymology - in reference to the aquatic habitat

Holotype - MFLU 17-1730

Saprobic on submerged wood in freshwater. Sexual morph: Undetermined. Asexual morph: Hyphomycetous. Colonies superficial, effuse, hairy, gregarious, dark brown. Mycelium partly immersed, partly superficial on host substrate, composed of septate, branched, pale brown, thinwalled hyphae. Conidiophores $125-215 \times 3-5 \mu \mathrm{m}(\bar{x}=175 \times 4 \mu \mathrm{m}, \mathrm{n}=10)$, macronematous, mononematous, erect, subcylindrical, flexuous, septate, slightly constricted at septa, unbranched, dark brown to black, thin-walled, smooth. Conidiogenous cells $10-85 \times 4-5.5 \mu \mathrm{m}(\bar{x}=47 \times 4.5$ $\mu \mathrm{m}, \mathrm{n}=5$ ), holoblastic, polyblastic, integrated, terminal, becoming intercalary, subcylindrical, pale 
brown, smooth, sympodial proliferations, bearing several prominent, rounded, dark brown to black denticles. Conidia 19-27.5 × 5-7.5 $\mathrm{m}(\bar{x}=24 \times 6 \mu \mathrm{m}, \mathrm{n}=20)$, acropleurogenous, solitary, dry, thin-walled, smooth, fusiform, slightly tapering towards the apex, straight or slightly curved, 3septate, slightly constricted at septa, cells often unequally coloured, olivaceous or brown in the middle cells, paler in the bipolar cells, often with a conspicuous, gelatinous, thin sheath, partially covering the conidia, $0.5-1.5 \mu \mathrm{m}$ thick.

Culture characteristics - On PDA, colony circular, reaching $20 \mathrm{~mm}$ in 27 days at $25^{\circ} \mathrm{C}$, graybrown from above, dark brown from below, surface rough, dry, with dense mycelium, raised, entire at edge.

Material examined - Thailand, Chiang Mai Province, Mushroom Research Centre, on submerged wood in a stream, 1 September 2017, X.D. Yu, 20A (MFLU 17-1730, holotype), extype living culture MFLUCC 17-2371.
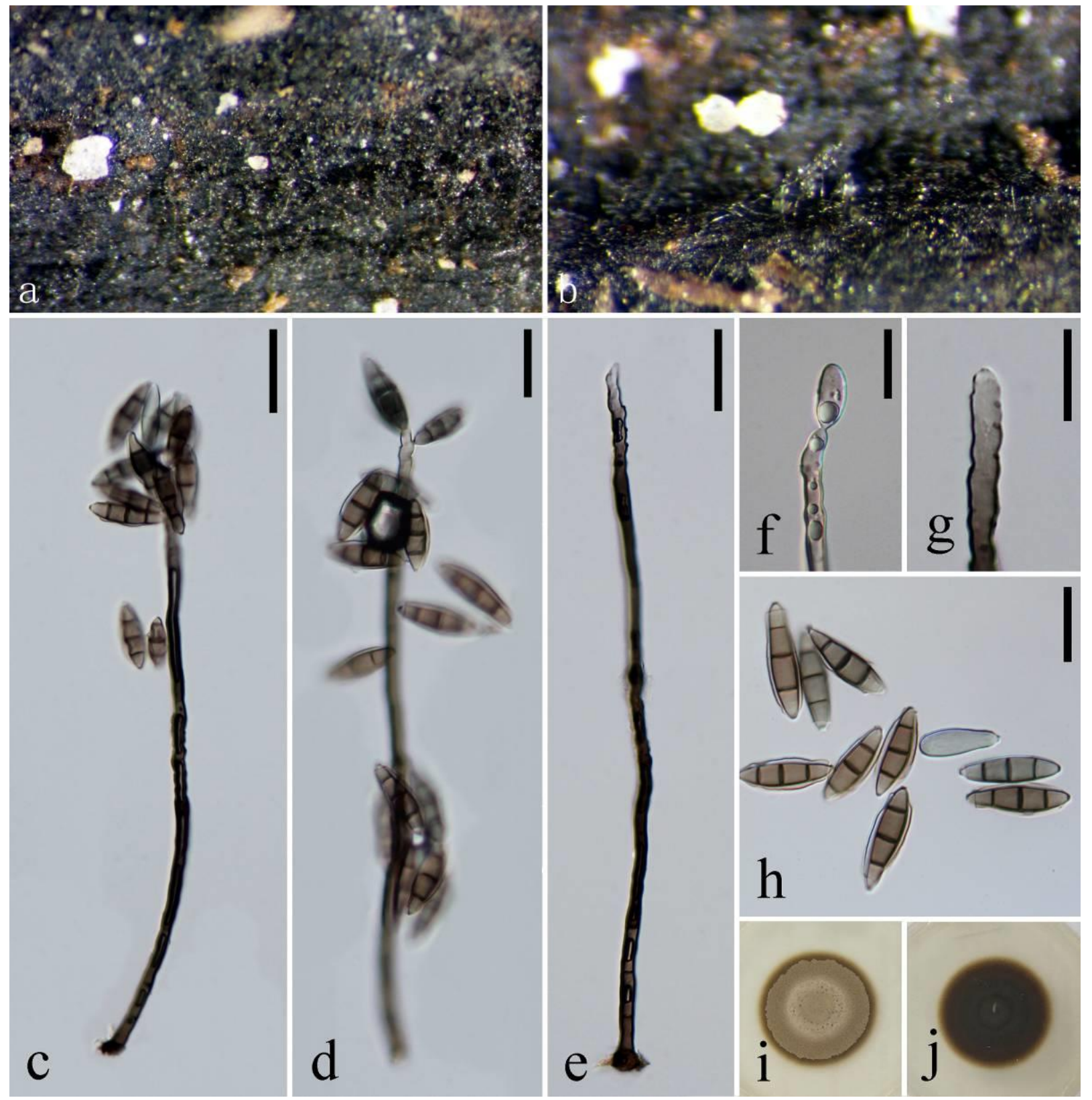

Figure 12 - Aquapteridospora aquatica (MFLU 17-1730, holotype). a, b Colonies on submerged wood. c-e Conidiophores with conidia. f Conidiogenous cell bearing young conidium. g Conidiogenous cell. h Conidia. i, j Colony on PDA (left-front, right-reverse). Scale bars: $\mathrm{c}=30$ $\mu \mathrm{m}, \mathrm{d}, \mathrm{e}, \mathrm{h}=20 \mu \mathrm{m}, \mathrm{f}, \mathrm{g}=10 \mu \mathrm{m}$. 
Notes - Aquapteridospora aquatica differs from its phylogenetically closest species Pleurophragmium bambusinum in having fusiform, unequally coloured, thin-walled conidia with a conspicuous, gelatinous, thin sheath. In contrast, P. bambusinum has ellipsoidal, equally coloured, thick-walled conidia without a sheath (Dai et al. 2017). Aquapteridospora aquatica is morphologically similar to the generic type A. lignicola, in having fusiform, 3-septate, unequally coloured conidia with a conspicuous sheath. The conidia of A. aquatica have tapering ends, while they have obtuse ends in A. lignicola. A nucleotide comparison between A. aquatica and A. lignicola shows a difference of 5 and 56 nucleotides in LSU and ITS sequence data, respectively, which supports them to be different species.

Distoseptisporaceae K.D. Hyde \& McKenzie, Fungal Diversity 80: 402 (2016)

Type genus - Distoseptispora K.D. Hyde, McKenzie \& Maharachch.

Notes - Distoseptisporaceae was introduced to accommodate a single genus Distoseptispora (Su et al. 2016). Distoseptisporaceae can be confused with Sporidesmiaceae in having distoseptate, obclavate or cylindrical conidia with tapering apices and truncate ends ( $\mathrm{Su}$ et al. 2016). However, phylogenetic analyses separate them in different families (Hyde et al. 2020, this study, Fig. 1). The sexual morph has been reported in Sporidesmiaceae and is morphologically similar to Annulatascaceae species (Zhang et al. 2017, Luo et al. 2019), while no sexual morph is found in Distoseptisporaceae.

Distoseptispora K.D. Hyde, McKenzie \& Maharachch., Fungal Diversity 80: 402 (2016)

Type species - Distoseptispora fluminicola McKenzie

Notes - Distoseptispora was introduced to accommodate species segregated from Sporidesmium with relatively short conidiophores, and long cylindrical, darker conidia with slightly paler, rounded apices (Su et al. 2016). However, D. lignicola and D. obclavata have paler conidia (Luo et al. 2019). The sexual morph of Sporidesmium has been linked to two annulatascaceae-like taxa, S. lignicola and S. thailandense (Zhang et al. 2017, Luo et al. 2019), while no sexual morph are reported for Distoseptispora. Phylogenetic analyses place Distoseptispora and Sporidesmium in Distoseptisporaceae and Sporidesmiaceae, respectively (Hyde et al. 2020, this study, Fig. 1). All Distoseptispora species have sequence data in GenBank and they clustered in a well-supported clade (Fig. 1). However, the morphological characteristics are not much correlated with their phylogenetic relationships as discussed in Monkai et al. (2020). The euseptate species Distoseptispora rayongensis clusters with the distoseptate species $D$. obclavata with strong bootstrap support; the new species $D$. songkhlaensis having distoseptate conidia clusters with an euseptate species $D$. guttulata in a well-supported clade; the euseptate species $D$. suoluoensis clusters with the distoseptate species D. bambusae in a distinct subclade within Distoseptispora (Fig. 1). Above examples reveal that the conidial septa in Distoseptispora species are not informative for generic delineation, but are highly informative at the species level. The asexual morphs of Distoseptispora are morphologically quite similar, thus their sexual morphs would be useful to better understand the taxonomy of Distoseptispora species. Distoseptispora species were commonly found from freshwater in China and Thailand (Su et al. 2016, Luo et al. 2018, 2019, Yang et al. 2018, Hyde et al. 2019, 2020). We introduce three new asexual species collected from submerged wood in Thailand.

Distoseptispora fasciculata W. Dong, H. Zhang \& K.D. Hyde, sp. nov.

Fig. 13

Index Fungorum number: IF558028; Facesoffungi number: FoF 09549

Etymology - name reflects the fasciculate conidiophores

Holotype - MFLU 18-1714

Saprobic on submerged wood in freshwater. Sexual morph: Undetermined. Asexual morph: Hyphomycetous. Colonies superficial, effuse, hairy, erect, gregarious, dark brown to black. Mycelium partly immersed, partly superficial on host substrate, composed of septate, branched, pale brown, thin-walled hyphae. Conidiophores $12-16 \times 5-6 \mu \mathrm{m}(\bar{x}=14 \times 5.7 \mu \mathrm{m}, \mathrm{n}=10)$, 
macronematous, mononematous, fasciculate, erect, cylindrical, straight, 0-1-septate, slightly constricted at septum, unbranched, brown, thin-walled, smooth. Conidiogenous cells 7-9 $\times 5-7 \mu \mathrm{m}$ $(\bar{x}=7.5 \times 6.5 \mu \mathrm{m}, \mathrm{n}=5)$, holoblastic, monoblastic, integrated, determinate, terminal, subcylindrical, brown, smooth. Conidia 46-200 × 10-16.5 $\mu \mathrm{m}(\bar{x}=112 \times 13.5 \mu \mathrm{m}, \mathrm{n}=15)$, acrogenous, solitary, dry, thin-walled, smooth, subcylindrical to obclavate, mostly curved, 10-40distoseptate, olivaceous when young, dark brown when mature, rounded at apex, with a protruding, cuneiform base and faintly pigmented scar.
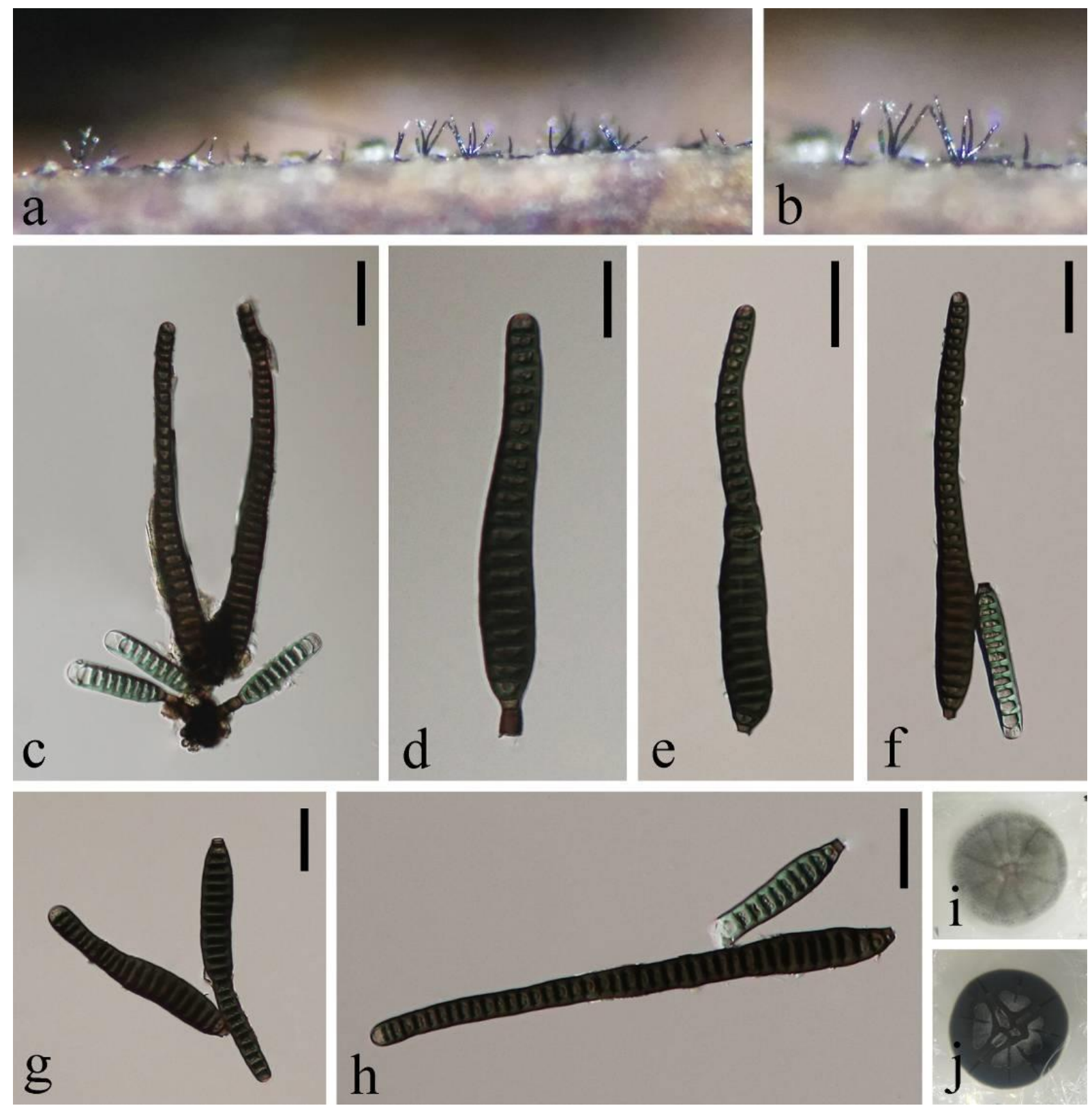

Figure 13 - Distoseptispora fasciculata (MFLU 18-1714, holotype). a, b Colonies on submerged wood. c Fasciculate conidiophores with conidia. d-h Conidia. i, j Colony on PDA (up-front, downreverse). Scale bars: c, e-h $=30 \mu \mathrm{m}, \mathrm{d}=20 \mu \mathrm{m}$.

Culture characteristics - On PDA, colony circular, reaching $30 \mathrm{~mm}$ in 23 days at $25^{\circ} \mathrm{C}$, gray from above, dark brown to black from below, surface rough, dry, with dense mycelium, raised, entire at edge.

Material examined - Thailand, Nakhon Si Thammarat Province, on submerged wood in a stream, 10 May 2018, W. Dong, hat6113 (MFLU 18-1714, holotype), ex-type living culture KUMCC 19-0081. 
Notes - Distoseptispora fasciculata is similar to its phylogenetically closest species $D$. fluminicola and D. xishuangbannaensis in conidial shape, but differs in having dark brown conidia when mature (brown in D. fluminicola and green in D. xishuangbannaensis) ( $\mathrm{Su}$ et al. 2016, Tibpromma et al. 2018). The conidiophores of $D$. fasciculata are obviously fasciculate, while they are solitary in D. fluminicola and D. xishuangbannaensis (Su et al. 2016, Tibpromma et al. 2018). Multigene analysis clearly supports the introduction of a new species (Fig. 1).

Distoseptispora saprophytica W. Dong, H. Zhang \& K.D. Hyde, sp. nov.

Fig. 14

Index Fungorum number: IF558029; Facesoffungi number: FoF 09550

Etymology - in reference to saprobic life mode of the fungus

Holotype - MFLU 18-1568

Saprobic on submerged wood in freshwater. Sexual morph: Undetermined. Asexual morph: Hyphomycetous. Colonies superficial, effuse, hairy, gregarious, brown. Mycelium partly immersed, partly superficial on host substrate, composed of septate, branched, pale brown, thin-walled hyphae. Conidiophores 50-140 × 3.2-4.2 $\mu \mathrm{m}(\bar{x}=92 \times 3.5 \mu \mathrm{m}, \mathrm{n}=10)$, macronematous, mononematous, erect, cylindrical, straight or slightly flexuous, or occasionally sharply curving near the base, septate, slightly constricted at septa, unbranched, brown, thin-walled, smooth. Conidiogenous cells 5-11.5 $\times 3-4.5 \mu \mathrm{m}(\bar{x}=8.5 \times 3.5 \mu \mathrm{m}, \mathrm{n}=10)$, holoblastic, mono- to poly-blastic, integrated, determinate, terminal, subcylindrical, brown, smooth. Conidia 14.5-30 $\times 4.5-7.5 \mu \mathrm{m}(\bar{x}=22 \times 6$ $\mu \mathrm{m}, \mathrm{n}=25$ ), acrogenous, solitary or occasionally catenate, dry, thin-walled, smooth, subcylindrical to obclavate, straight or curved, 2-6-distoseptate, slightly constricted at septa, olivaceous to brown, rounded at apex, with a truncate base and faintly pigmented scar.

Culture characteristics - On PDA, colony circular, reaching $15 \mathrm{~mm}$ in 25 days at $25^{\circ} \mathrm{C}$, white-brown from above, black from below, surface rough, dry, with dense mycelium, raised, entire at edge.

Material examined - Thailand, Songkhla Province, on submerged wood in a stream, 10 May 2018, W. Dong, hat162 (MFLU 18-1568, holotype), ex-type living culture MFLUCC 18-1238.

Notes - Distoseptispora saprophytica clusters with $D$. palmarum with strong bootstrap support (Fig. 1). Distoseptispora saprophytica differs from D. palmarum in having shorter and thinner $(14.5-30 \times 4.5-7.5 \mu \mathrm{m}$ vs. $35-180 \times 7-11 \mu \mathrm{m})$, less septate $(2-6 \mathrm{vs}$. 7-27) conidia and different conidial shape (mostly subcylindrical vs. mostly obclavate) (Hyde et al. 2019). The relatively longer conidiophores, mono- to poly-blastic conidiogenous cells, with short, subcylindrical and occasionally catenate conidia of $D$. saprophytica are distinctive in the genus.

Distoseptispora songkhlaensis W. Dong, H. Zhang \& K.D. Hyde, sp. nov.

Fig. 15

Index Fungorum number: IF558030; Facesoffungi number: FoF 09551

Etymology - in reference to Songkhla, from where the holotype was collected

Holotype - MFLU 18-1538

Saprobic on submerged wood in freshwater. Sexual morph: Undetermined. Asexual morph: Hyphomycetous. Colonies superficial, effuse, hairy, gregarious, brown. Mycelium partly immersed, partly superficial on host substrate, composed of septate, branched, pale brown, thin-walled hyphae. Conidiophores $70-90 \times 4-5.5 \mu \mathrm{m}(\bar{x}=76 \times 4.7 \mu \mathrm{m}, \mathrm{n}=10)$, macronematous, mononematous, erect, cylindrical, slender, straight or slightly flexuous, septate, slightly constricted at septa, unbranched, brown, thin-walled, smooth. Conidiogenous cells $15.2-16.5 \times 4-5 \mu \mathrm{m}(\bar{x}=15.7 \times 4.5$ $\mu \mathrm{m}, \mathrm{n}=10$ ), holoblastic, monoblastic, integrated, determinate, terminal, subcylindrical, tapering towards the apex, brown, smooth. Conidia 44-125 $\times 9-14.5 \mu \mathrm{m}(\bar{x}=90 \times 11.5 \mu \mathrm{m}, \mathrm{n}=25)$, acrogenous, solitary, dry, thin-walled, smooth, obclavate, straight or curved, 9-16-distoseptate, slightly or occasionally deeply constricted at septa, olivaceous to brown, rounded at apex, with a protruding, cuneiform base and faintly to heavily pigmented scar.

Culture characteristics - On PDA, colony circular, reaching $40 \mathrm{~mm}$ in 30 days at $25^{\circ} \mathrm{C}$, white-brown from above, black from below, surface rough, dry, with dense mycelium, raised, undulate at edge. 

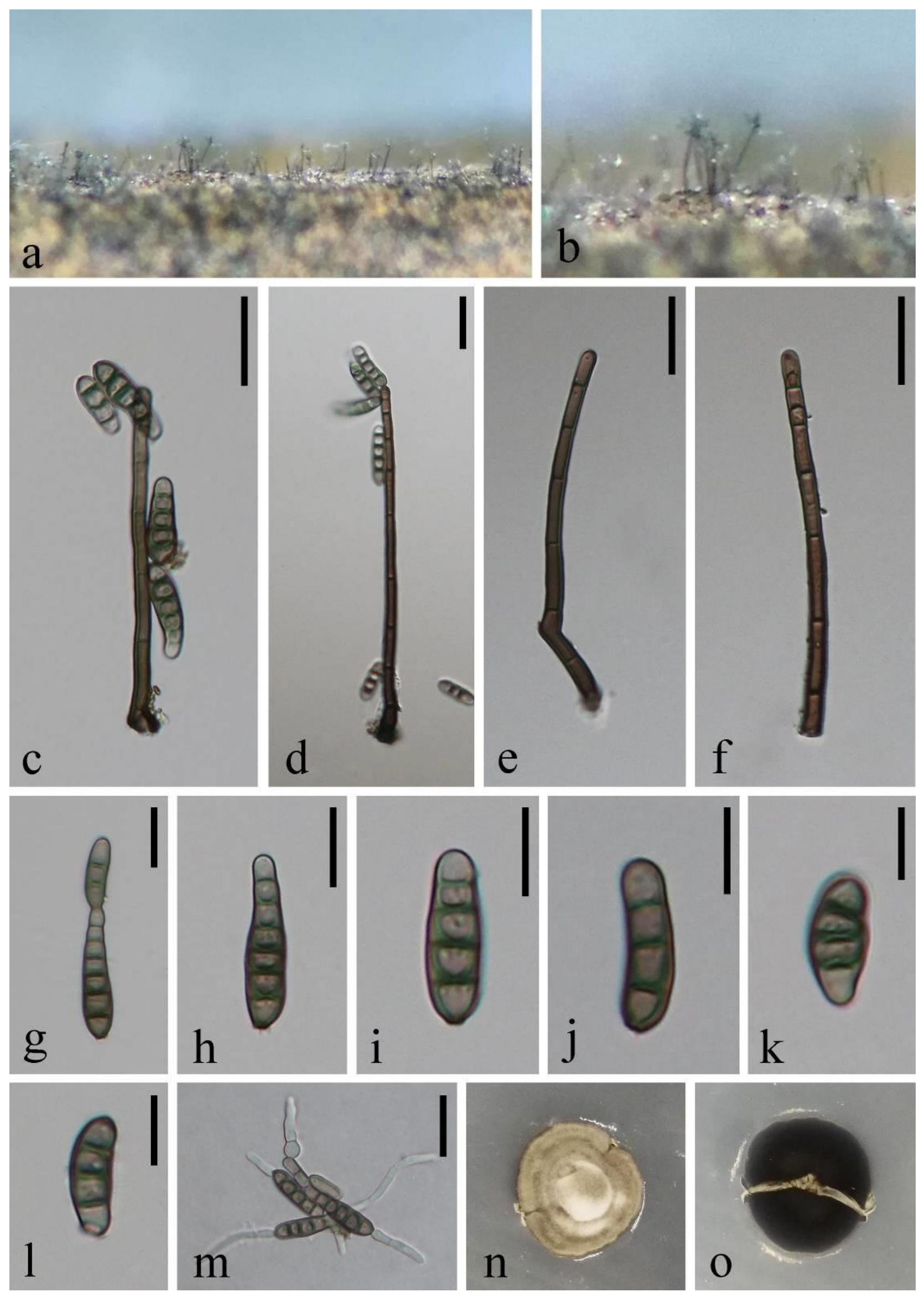

Figure 14 - Distoseptispora saprophytica (MFLU 18-1568, holotype). a, b Colonies on submerged wood. c, d Conidiophores with conidia. e, f Conidiophores. g-l Conidia. m Germinated conidia. $\mathrm{n}, \mathrm{o}$ Colony on PDA (left-front, right-reverse). Scale bars: $\mathrm{c}-\mathrm{f}, \mathrm{m}=20 \mu \mathrm{m}, \mathrm{g}-1=10 \mu \mathrm{m}$. 
Material examined - Thailand, Songkhla Province, on submerged wood in a stream, 10 May 2018, W. Dong, hat141 (MFLU 18-1538, holotype), ex-type living culture MFLUCC 18-1234.

Notes - Distoseptispora songkhlaensis clusters with Distoseptispora sp. DLUCC B43 and D. guttulata with high bootstrap support (Fig. 1). Distoseptispora songkhlaensis is similar to D. guttulata in having obclavate conidia, but differs in having shorter and wider conidia $(44-125 \times 9$ $14.5 \mu \mathrm{m}$ vs. $75-165 \times 7-11 \mu \mathrm{m}$ ) (Yang et al. 2018). A nucleotide comparison between $D$. songkhlaensis and D. guttulata shows a difference of 3 and 28 nucleotides in LSU and ITS sequence data, respectively, which indicates that they are different species (Jeewon \& Hyde 2016).
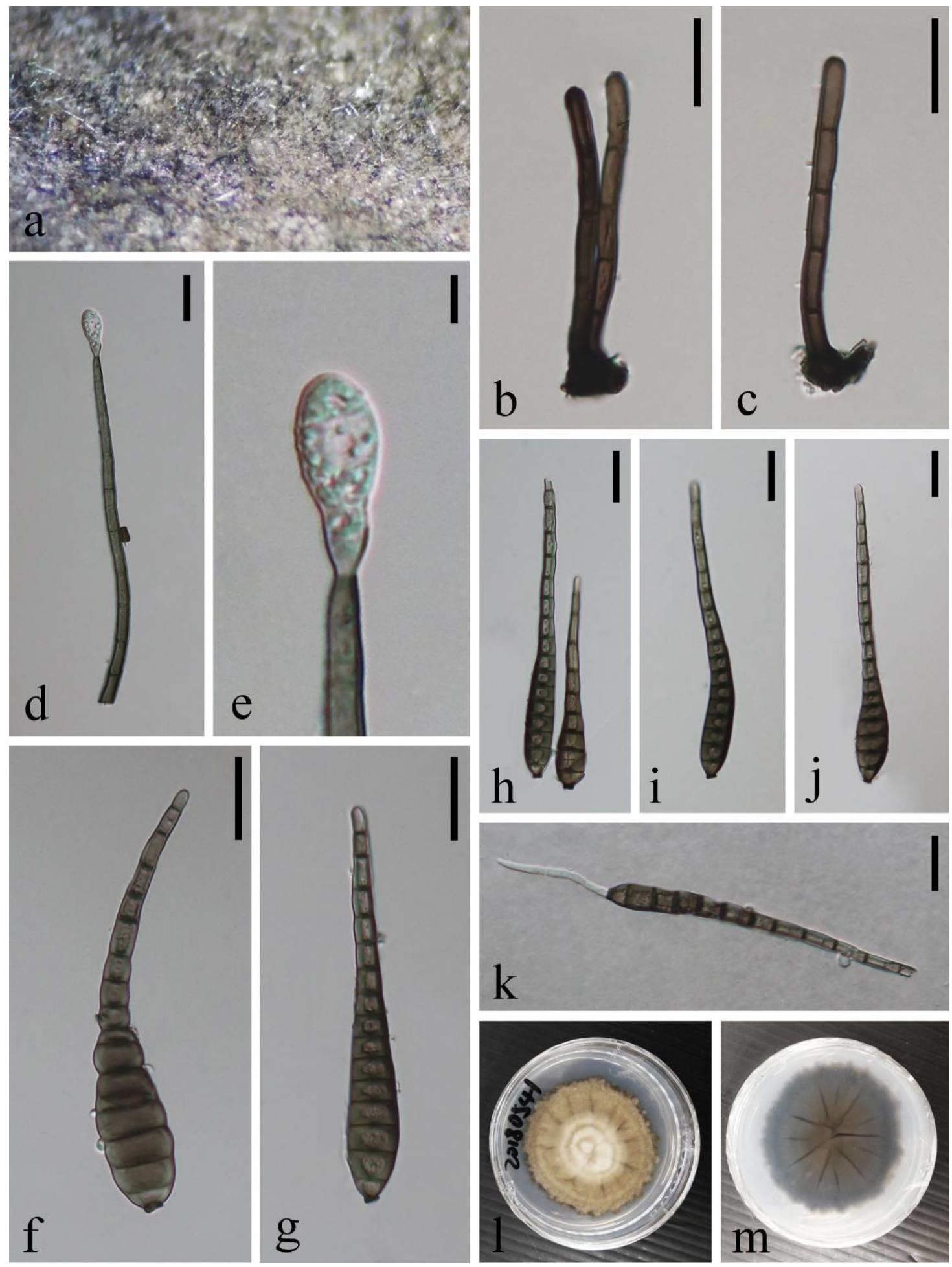

Figure 15 - Distoseptispora songkhlaensis (MFLU 18-1538, holotype). a Colonies on submerged wood. b, c Conidiophores. d Conidiophore with immature conidium. e Conidiogenous cell with 
immature conidium. $\mathrm{f}-\mathrm{j}$ Conidia. $\mathrm{k}$ Germinated conidium. $1, \mathrm{~m}$ Colony on PDA (left-front, rightreverse). Scale bars: $b-d, f-k=20 \mu \mathrm{m}, \mathrm{e}=5 \mu \mathrm{m}$.

Strain DLUCC B43 was named as D. guttulata based on their similar morphological characters (Luo et al. 2019). However, there are 4 and 44 nucleotide differences in LSU and ITS sequence data between DLUCC B43 and ex-type strain of D. guttulata MFLUCC 16-0183, respectively, which indicates that they are different species. DLUCC B43 clusters with our new species D. songkhlaensis (Fig. 1), but they are different species as the former has quite longer conidia $(70-520 \times 8.5-10.5 \mu \mathrm{m}$ vs. $44-125 \times 9-14.5 \mu \mathrm{m})$ and more septa (9-27 vs. 9-16). In addition, there are 4 and 28 nucleotide differences in LSU and ITS sequence data between DLUCC B43 and D. songkhlaensis, which also support them to be different species. Presently, we do not name DLUCC B43 as a new species until new collections are obtained.

Distoseptispora tectonae Doilom \& K.D. Hyde, Fungal Diversity 80: 222 (2016)

Fig. 16

Synonym - Distoseptispora submersa Z.L. Luo, K.D. Hyde \& H.Y. Su, Mycosphere 9(3): 454 (2018)

Saprobic on submerged wood in freshwater. Sexual morph: Undetermined. Asexual morph: Hyphomycetous. Colonies superficial, effuse, hairy, gregarious, dark brown to black. Mycelium partly immersed, partly superficial on host substrate, composed of septate, branched, pale brown, thin-walled hyphae. Conidiophores 19.5-50 $\times$ 4.5-5.5 $\mu \mathrm{m}(\bar{x}=30 \times 5 \mu \mathrm{m}, \mathrm{n}=10)$, macronematous, mononematous, erect, cylindrical, straight or slightly flexuous, septate, slightly constricted at septa, robust at the base, unbranched, brown, thin-walled, smooth. Conidiogenous cells 6.7-9 $\times$ 4-5.5 $\mu \mathrm{m}(\bar{x}=7.5 \times 4.7 \mu \mathrm{m}, \mathrm{n}=10)$, holoblastic, monoblastic, integrated, determinate, terminal, subcylindrical, brown, smooth. Conidia 45-270 $\times 11-16 \mu \mathrm{m}(\bar{x}=165 \times$ $13.5 \mu \mathrm{m}, \mathrm{n}=20$ ), acrogenous, solitary, dry, thin-walled, smooth, obclavate, mostly curved, 10-40distoseptate, brown to dark brown, olivaceous, rounded at apex, with a truncate base and faintly to heavily pigmented scar.

Culture characteristics - On PDA, colony circular, reaching $40 \mathrm{~mm}$ in 25 days at $25^{\circ} \mathrm{C}$, gray to dark gray from above, dark brown to black from below, surface rough, dry, with dense mycelium, raised, entire at edge.

Material examined - Thailand, Prachuap Khiri Khan Province, on submerged wood in a stream, 30 July 2015, W. Dong, 45B (MFLU 15-2693), living culture MFLUCC 15-0981.

Notes - Distoseptispora tectonae was initially collected from a dead twig of Tectona grandis (Hyde et al. 2016b). Luo et al. (2018) introduced one phylogenetically close species D. submersa based on larger conidiophores $(55-73 \times 7-9 \mu \mathrm{m}$ vs. up to $40 \times 4-6 \mu \mathrm{m})$. A recent new collection which has larger conidiophores $(34-95 \times 5-8 \mu \mathrm{m}$ vs. up to $40 \times 4-6 \mu \mathrm{m})$ than the holotype of $D$. tectonae was, however, identified as D. tectonae (Sun et al. 2020). It indicates that the conidiophore dimension can be varied in $D$. tectonae, and $D$. submersa is likely to be a synonym of $D$. tectonae. A nucleotide comparison between $D$. tectonae and D. submersa shows a difference of four (include two gaps), two and three nucleotides in ITS, TEF and RPB2 sequence data, respectively, which indicates that they are conspecific (Jeewon \& Hyde 2016). Our phylogenetic analysis clearly shows they are the same species (Fig. 1). We therefore synonymize D. submersa with D. tectonae.

Our new collection MFLUCC 15-0981 clusters with three collections of D. tectonae with high bootstrap support (Fig. 1). It has slightly longer conidiophores (up to $50 \mu \mathrm{m}$ vs. up to $40 \mu \mathrm{m}$ ) and longer conidia (45-270 × 11-16 $\mu \mathrm{m}$ vs. 90-170 $\times 11-16 \mu \mathrm{m})$ than the holotype of $D$. tectonae (Hyde et al. 2016b). Except brown conidia described by Hyde et al. (2016b) and Sun et al. (2020), we found olivaceous conidia in our collection. Phylogenetic analysis supports MFLUCC 15-0981 to be D. tectonae.

Sporidesmiales Crous, Persoonia 40: 377 (2018)

Type family - Sporidesmiaceae Fr. 

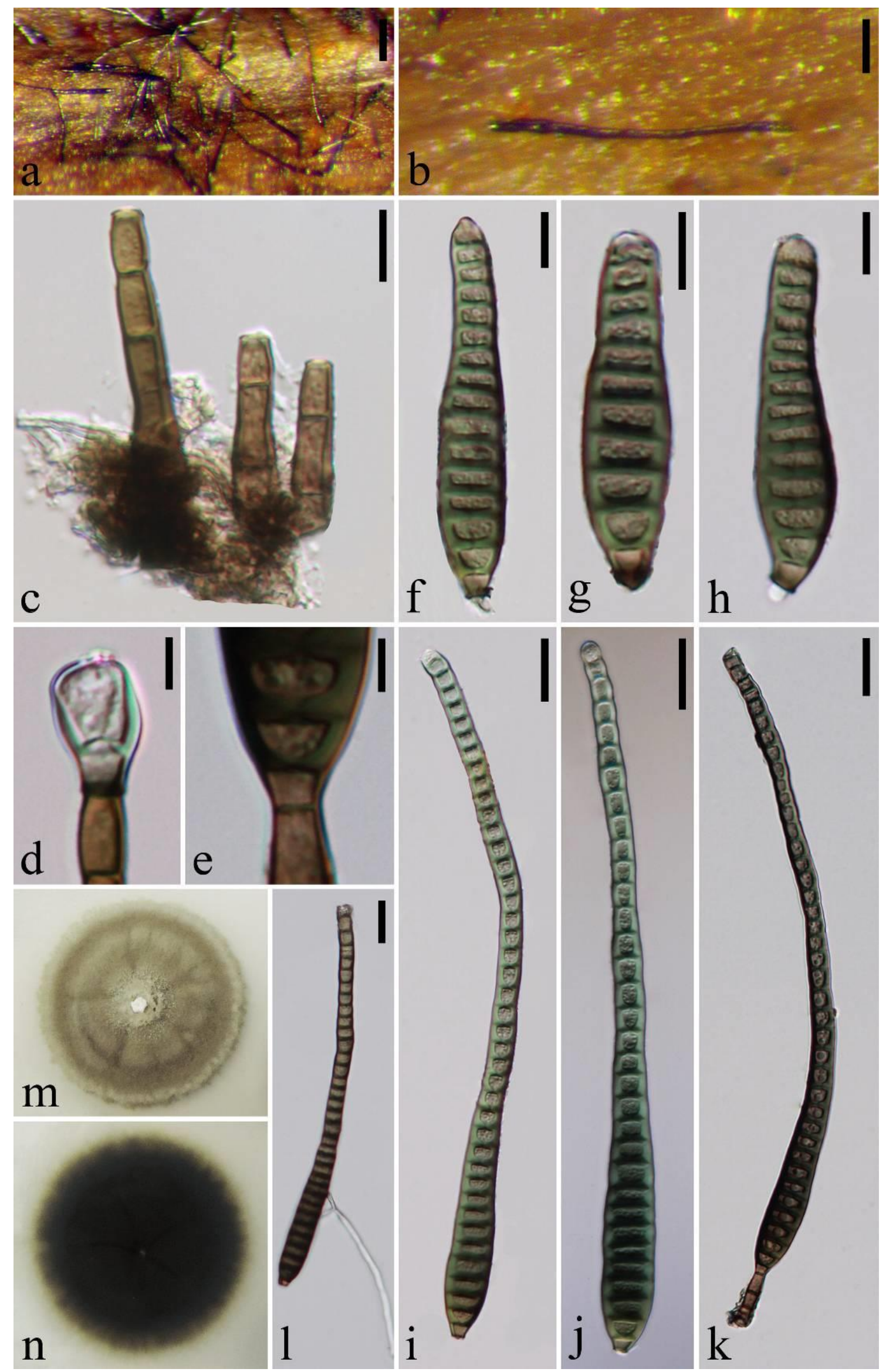

Figure 16 - Distoseptispora tectonae (MFLU 15-2693). a, b Colonies on submerged wood. c Conidiophores. d, e Conidiogenous cells with conidia. f-k Conidia. 1 Germinated conidium. 
$\mathrm{m}, \mathrm{n}$ Colony on PDA (up-front, down-reverse). Scale bars: $\mathrm{a}=100 \mu \mathrm{m}, \mathrm{b}=50 \mu \mathrm{m}, \mathrm{c}, \mathrm{f}-\mathrm{h}=10 \mu \mathrm{m}$, $\mathrm{d}, \mathrm{e}=5 \mu \mathrm{m}, \mathrm{i}-1=20 \mu \mathrm{m}$.

Notes - Sporidesmiales was established by Crous et al. (2018) for a single family Sporidesmiaceae. The ordinal status was confirmed by Hyde et al. (2021) based on a divergence time study. The divergence time was estimated as 133 MYA, which fell in the range of an order (Hyde et al. 2021).

Sporidesmiaceae Fr. [as 'Sporidemsiacei'], Summa veg. Scand., Sectio Post. (Stockholm): 504 (1849)

Type genus - Sporidesmium Link

Notes - Sporidesmiaceae was widely used since the molecular work was carried out by Su et al. (2016). Sporidesmiaceae comprises a single genus Sporidesmium, however, Sporidesmium has been shown to be polyphyletic (Yang et al. 2018, Liu et al. 2019). Some sporidesmium-like taxa, which are phylogenetically distant from Sporidesmiaceae sensu stricto, have been placed in Distoseptisporaceae ( $\mathrm{Su}$ et al. 2016), while others are uncertain. Distoseptisporaceae and Sporidesmiaceae are morphologically very similar, and DNA sequence data is the main evidence to delimit the two families. The family status of Sporidesmiaceae was confirmed by Hyde et al. (2020) based on a divergence time study.

Sporidesmium Link, Mag. Gesell. naturf. Freunde, Berlin 3(1-2): 41 (1809)

Type species - Sporidesmium ehrenbergii M.B. Ellis

Notes - Sporidesmium is broadly characterized by solitary or gregarious conidiophores, monoblastic conidiogenous cells, and pale brown to brown, cylindrical, fusiform, obclavate, obpyriform, sometimes rostrate conidia with hyaline apex and truncate base (Ellis 1971, Su et al. 2016). These morphological characteristics are common in asexual hyphomycetes, which result in almost 500 epithets in Sporidesmium (Index Fungorum 2021). Based on morphological characteristics of conidiophores, conidiogenous cells and conidia, some new genera were segregated from Sporidesmium, e.g. Distoseptispora, Ellisembia, Repetophragma and Sporidesmiella (Subramanian 1992, Hernandez-Gutierrez \& Sutton 1997, Su et al. 2016). Ellisembia, however, previously segregated from Sporidesmium due to the distoseptate conidia, is now synonymized with Sporidesmium based on molecular evidence ( $\mathrm{Su}$ et al. 2016). The polyphyletic nature of Sporidesmium has been shown based on phylogenetic analyses (Shenoy et al. 2006, Yang et al. 2018, Liu et al. 2019).

Sequence data of the type species Sporidesmium ehrenbergii is lacking. Several Sporidesmium species, which were confirmed by molecular data, are represented as Sporidesmium sensu stricto, and this is accepted by Su et al. (2016) and Yang et al. (2018). Sporidesmium sensu lato species were scattered in Hypocreomycetidae, Sordariomycetidae and Xylariomycetidae, and some clustered with Papulosaceae in Diaporthomycetidae (Yang et al. 2018). Sexual morph of Sporidesmium, S. thailandense, was first reported by Zhang et al. (2017) based on molecular data, and re-collected by Yang et al. (2018). Luo et al. (2019) reported the second sexual morph $S$. lignicola, which differs from $S$. thailandense in having smaller asci and aseptate, smaller ascospores. The morphological characteristics of sexual morphs, such as immersed ascomata with neck erumpent through host substrate, cylindrical asci with a distinct, refractive, wedge-shaped, apical ring, and fusiform, hyaline ascospores, are similar to Annulatascus (Annulatascaceae) and Fluminicola (Papulosaceae).

The asexual morphs of Sporidesmium are commonly found in freshwater in China and Thailand (Su et al. 2016, Yang et al. 2018, Luo et al. 2019). We introduce two new species in Sporidesmium which were collected from submerged wood in Thailand. Phylogenetic analysis places them in Sporidesmium sensu stricto (Fig. 1). The information of many Sporidesmium species are lost as they were published since in 1800s or early 1900s. Therefore, the new species are introduced based on available literature and molecular data. 
Sporidesmium appendiculatum G.N. Wang, W. Dong \& H. Zhang, sp. nov.

Index Fungorum number: IF558032; Facesoffungi number: FoF 09553

Etymology - in reference to apical appendage of the conidia

Holotype - MFLU 18-0981

Saprobic on submerged wood in freshwater. Sexual morph: Undetermined. Asexual morph: Hyphomycetous. Colonies superficial, effuse, gregarious, hairy, black. Mycelium partly immersed, composed of septate, brown, thin-walled hyphae. Conidiophores 33-60 $\times 4.8-6.2 \mu \mathrm{m}(\bar{x}=42.5 \times$ $5.5 \mu \mathrm{m}, \mathrm{n}=10$ ), macronematous, mononematous, erect, cylindrical, straight or slightly flexuous, septate, with dark bands at the septa, robust at the base, unbranched, brown to dark brown, smooth. Conidiogenous cells 16.5-20.5 $\times 3.7-5.5 \mu \mathrm{m}(\bar{x}=18.5 \times 4.9 \mu \mathrm{m}, \mathrm{n}=10)$, holoblastic, monoblastic, integrated, determinate, terminal, cylindrical or flask-shaped, slightly tapering towards the conidial base, brown to dark brown, smooth. Conidia 40-55 $\times 12-16 \mu \mathrm{m}(\bar{x}=49.5 \times$ $14 \mu \mathrm{m}, \mathrm{n}=10$ ), acrogenous, solitary, dry, thin-walled, smooth-walled, obclavate with a protruding, truncate, cuneiform, darker base, tapering towards apex, pale brown to hyaline in apical two cells, straight or curved, brown in water, olivaceous in Congo red, 9-11-distoseptate, guttulate, apex with 1-3 hyaline, hypha-like appendages, up to $22 \mu \mathrm{m}$ long, and with a conspicuous, gelatinous, oblong, hyaline sheath, covering apical two cells.

Material examined - Thailand, Chiang Mai Province, on submerged wood in a stream, 29 March 2018, G.N. Wang, L4 (MFLU 18-0981, holotype).

Notes - Sporidesmium appendiculatum is distinctive in the genus in having both appendage and sheath. Sporidesmium appendiculatum is similar to $S$. minigelatinosum in having obclavate conidia with an apical sheath. However, it differs by wider conidia (40-55 × 12-16 $\mu \mathrm{m}$ vs. 36-50 $\times$ 6-8 $\mu \mathrm{m}$ ) and hypha-like appendages (Matsushima 1971). The obclavate conidia with an apical sheath of $S$. appendiculatum also resemble those of $S$. aquaticivaginatum, $S$. guizhouense and $S$. olivaceoconidium (Hyde et al. 2016b, Liu et al. 2019). However, S. appendiculatum is distinctive by 1-3 hyaline, hypha-like appendages at the apex, and molecular evidence places $S$. appendiculatum in Sporidesmium sensu stricto (Fig. 1) and S. aquaticivaginatum, S. guizhouense and S. olivaceoconidium in Sporidesmium sensu lato (Liu et al. 2019).

Sporidesmium chiangmaiense X.D. Yu, W. Dong \& H. Zhang, sp. nov.

Fig. 18

Index Fungorum number: IF558033; Facesoffungi number: FoF 09554

Etymology - in reference to Chiang Mai, where the holotype was collected

Holotype - MFLU 18-1013

Saprobic on submerged wood in freshwater. Sexual morph: Undetermined. Asexual morph: Hyphomycetous. Colonies superficial, effuse, gregarious, hairy, black. Mycelium partly immersed, composed of septate, brown, thin-walled hyphae. Conidiophores $29-54 \times 3.8-5 \mu \mathrm{m}(\bar{x}=37 \times 4.5$ $\mu \mathrm{m}, \mathrm{n}=10$ ), macronematous, mononematous, fasciculate, erect, cylindrical, straight or flexuous, septate, with dark bands at the septa, unbranched, brown or olivaceous, smooth. Conidiogenous cells 18-20 × 4-5.3 $\mu \mathrm{m}(\bar{x}=19 \times 5 \mu \mathrm{m}, \mathrm{n}=10)$, holoblastic, monoblastic, integrated, determinate, terminal, subcylindrical, brown or olivaceous, smooth. Conidia 54-71.5 $\times 10.5-14 \mu \mathrm{m}(\bar{x}=62 \times$ $12 \mu \mathrm{m}, \mathrm{n}=15$ ), acrogenous, solitary, dry, thin-walled, smooth, obclavate to fusiform, straight or curved, pale olivaceous or brown, with a truncate, cuneiform base, tapering towards apex, pale brown to hyaline in apical cells, (8-)12-distoseptate, guttulate, apex with a hyaline, filamentous appendage, up to $40 \mu \mathrm{m}$ long, and often with a conspicuous, gelatinous, oblong, hyaline sheath, covering apical $2-3$ cells.

Material examined - Thailand, Chiang Mai Province, on submerged wood in a stream, 29 March 2018, X.D. Yu, Y36 (MFLU 18-1013, holotype), ex-type living culture MFLUCC 18-0999.

Notes - Sporidesmium chiangmaiense clusters with $S$. appendiculatum with high bootstrap support (Fig. 1). They share similar morphological characteristics in having obclavate, olivaceous or brown conidia with an apical appendage and sheath. However, S. chiangmaiense has longer conidia $(54-71.5 \times 10.5-14 \mu \mathrm{m}$ vs. $40-55 \times 12-16 \mu \mathrm{m}$ ), longer (up to $40 \mu \mathrm{m}$ long vs. up to $22 \mu \mathrm{m}$ long) and single appendage. A nucleotide comparison between $S$. chiangmaiense and $S$. 
appendiculatum shows a difference of 4 and 44 nucleotides in LSU and ITS sequence data, respectively, which supports them to be different species (Jeewon \& Hyde 2016).
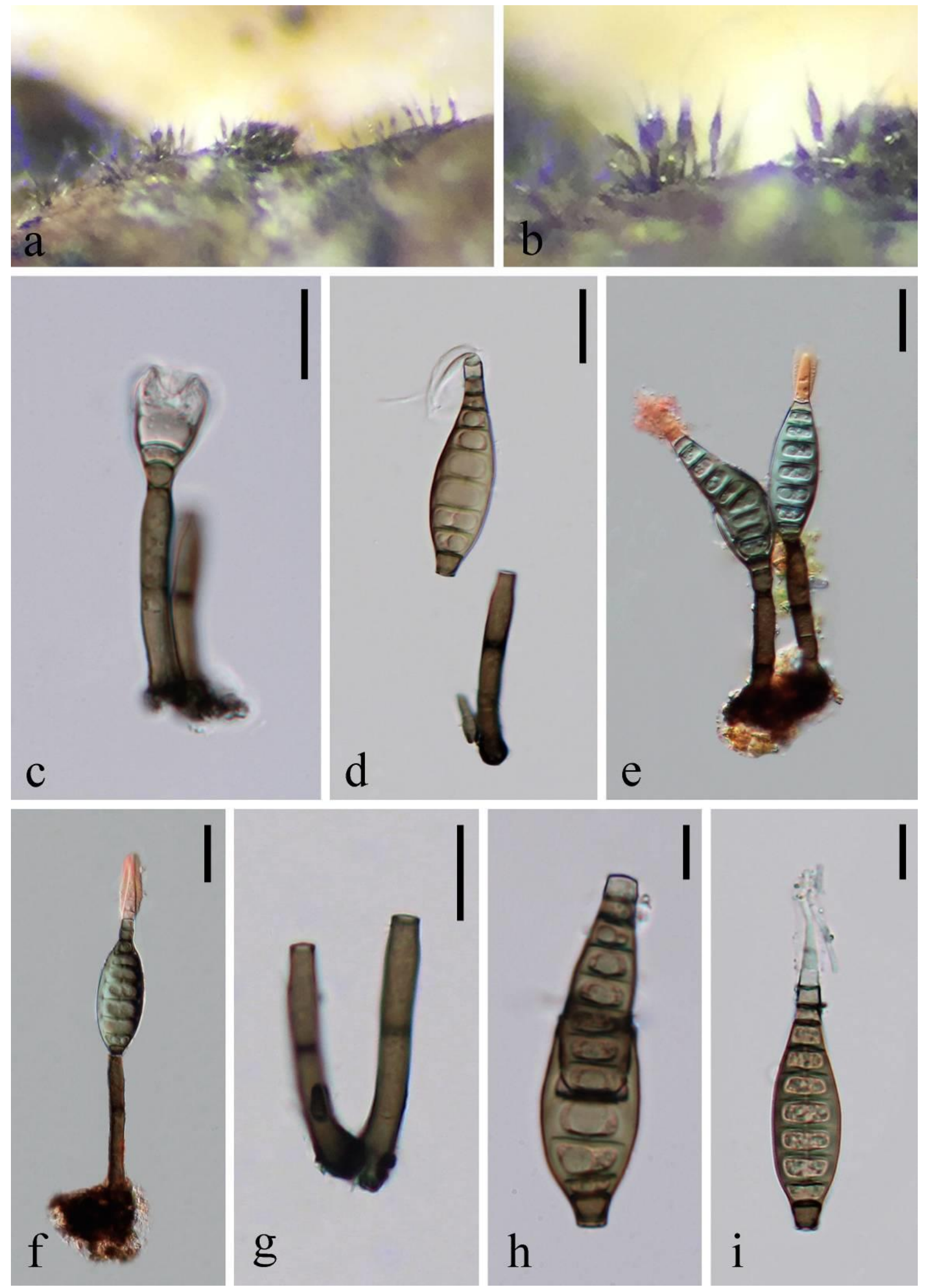

Figure 17 - Sporidesmium appendiculatum (MFLU 18-0981, holotype). a, b Colonies on submerged wood. c-f Conidiophores with conidia (e, f materials stained with Congo red). 
g Conidiophores. $\mathrm{h}-\mathrm{i}$ Conidia (h two overlapping conidia). Scale bars: $\mathrm{c}, \mathrm{d}, \mathrm{g}=15 \mu \mathrm{m}, \mathrm{e}, \mathrm{f}=20$ $\mu \mathrm{m}, \mathrm{h}, \mathrm{i}=10 \mu \mathrm{m}$.
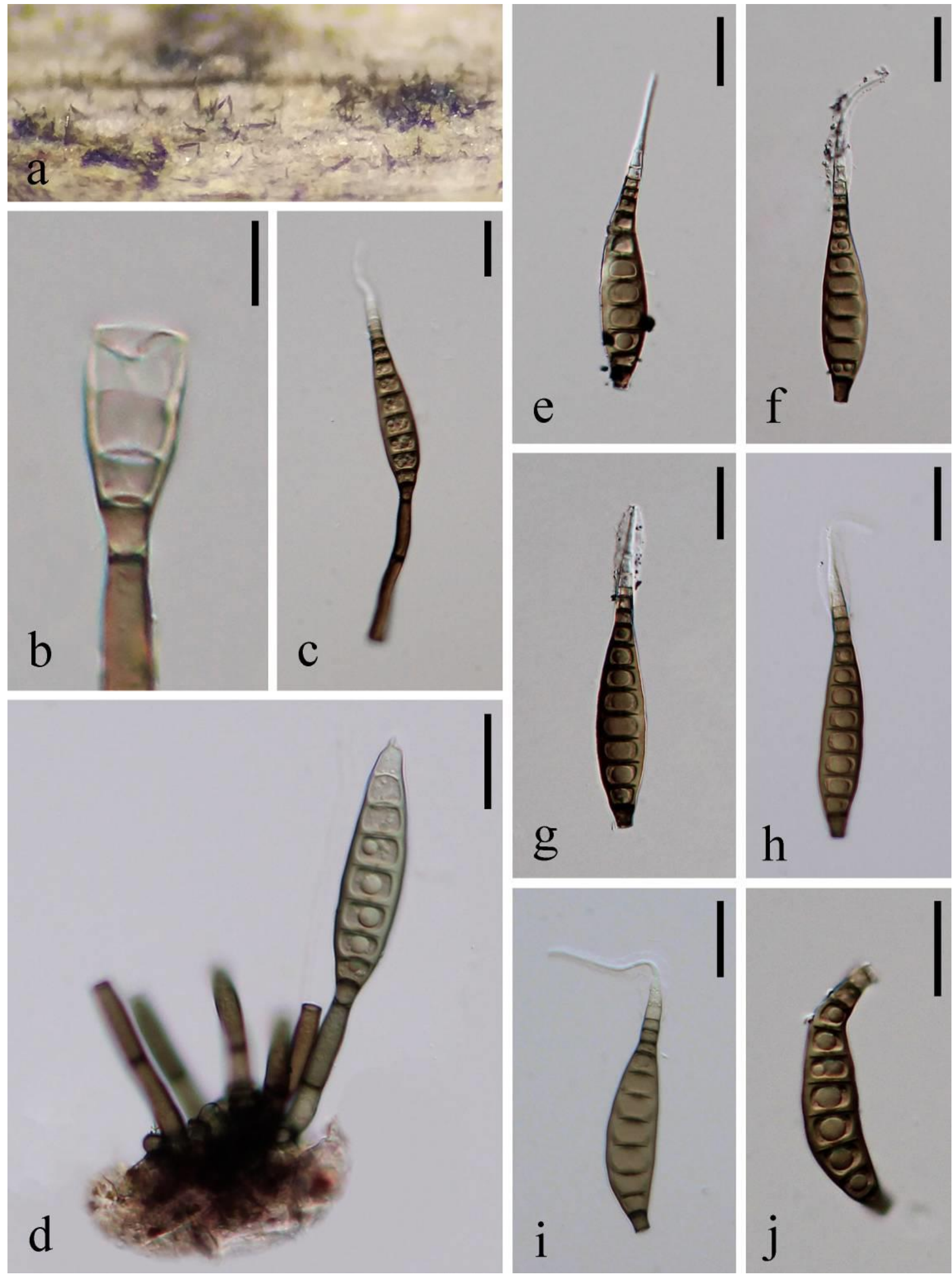

Figure 18 - Sporidesmium chiangmaiense (MFLU 18-1013, holotype). a Colonies on submerged wood. $\mathrm{b}-\mathrm{d}$ Conidiophores with conidia. $\mathrm{e}-\mathrm{j}$ Conidia. Scale bars: $\mathrm{b}=10 \mu \mathrm{m}, \mathrm{c}-\mathrm{j}=20 \mu \mathrm{m}$. 


\section{Diaporthomycetidae families incertae sedis}

Acrodictyaceae J.W. Xia \& X.G. Zhang, Scientific Reports 7(no. 7888): 2 (2017)

Type genus - Acrodictys M.B. Ellis

Notes - Acrodictyaceae was introduced to accommodate a single genus Acrodictys characterized by acrogenous, obovoid to pyriform, muriform conidia (Xia et al. 2017). The phylogenetic position of Acrodictyaceae is unstable, as it clusters with Junewangiaceae, Papulosaceae or Sporidesmiaceae in different studies (Xia et al. 2017, Luo et al. 2019, Hyde et al. 2020). All these three families have annulatascaceae-like sexual morphs, e.g. Dictyosporella thailandensis in Junewangiaceae, Fluminicola aquatica in Papulosaceae, and Sporidesmium thailandense in Sporidesmiaceae (Zhang et al. 2017). However, no sexual morph is linked to Acrodictyaceae. Although the placement of Acrodictyaceae is unstable, it clusters with Diaporthomycetidae families in all studies (Luo et al. 2019, Hyde et al. 2020, this study, Fig. 1). We therefore refer Acrodictyaceae to Diaporthomycetidae families incertae sedis.

Acrodictys M.B. Ellis, Mycol. Pap. 79: 5 (1961)

Type species - Acrodictys bambusicola M.B. Ellis

Notes - Acrodictys was introduced to accommodate species having conidiophores often with successive terminal proliferations, and variable-shaped, dictyoseptate, pale brown to dark blackish brown conidia (Ellis 1961). The type species A. bambusicola was initially collected in Venezuela (Ellis 1961), later collected and sequenced from China (Xia et al. 2017). Acrodictys is confused with Junewangia as both genera have long conidiophores with percurrent proliferations, and dictyoseptate conidia often with a protruding base (Xia et al. 2017). However, phylogenetic analysis places them in Acrodictyaceae and Junewangiaceae, respectively (Fig. 1). The latest treatment was carried out by Luo et al. (2019), who introduced a new species A. fluminicola and a new combination A. aquatica in Acrodictys. We redescribe and illustrate A. porosiseptata in this study.

Acrodictys porosiseptata G.Z. Zhao, Mycol. Progr. 10(1): 74 (2011)

Fig. 19

Facesoffungi number: FoF 09555

Saprobic on submerged wood in freshwater. Sexual morph: Undetermined. Asexual morph: Hyphomycetous. Colonies superficial, effuse, scattered, hairy, blackish brown. Mycelium partly immersed, composed of septate, branched, pale brown, thin-walled hyphae. Conidiophores 90-160 $\times 3-5.5 \mu \mathrm{m}(\bar{x}=133 \times 4.5 \mu \mathrm{m}, \mathrm{n}=10)$, macronematous, mononematous, erect, cylindrical, narrower and paler toward the apex, straight or flexuous, septate, slightly constricted at septa, unbranched, brown to dark brown, smooth, with one or more successive, terminal, percurrent proliferations. Conidiogenous cells 13-15 × 2.5-3.7 $\mu \mathrm{m}(\bar{x}=13.5 \times 3 \mu \mathrm{m}, \mathrm{n}=5)$, holoblastic, monoblastic, integrated, terminal, lageniform, pale brown, smooth. Conidia 20-26 × 12.5-14 $\mu \mathrm{m}$ $(\bar{x}=24 \times 13 \mu \mathrm{m}, \mathrm{n}=15)$, acrogenous, solitary, dry, thin-walled, smooth-walled, broadly clavate, obpyriform, dictyoseptate, usually with 4-5 transverse and 2 longitudinal septa, and 1-2 oblique septa at the apex, with several conspicuous pores on the surface, brown to dark brown, smooth, with a protruding, subhyaline, obconical or cuneiform, truncate base, 3-4.5 $\mu \mathrm{m}$ long, 5-5.5 $\mu \mathrm{m}$ wide at the top, 1.8-2.7 $\mu \mathrm{m}$ wide at the base. Conidial secession schizolytic.

Culture characteristics - On PDA, colony circular, reaching $10 \mathrm{~mm}$ in 12 days at $25^{\circ} \mathrm{C}$, grey from above, black from below, surface rough, dry, with dense mycelium, umbonate, entire at edge.

Material examined - Thailand, Chiang Rai Province, on submerged wood in a stream, 26 February 2011, H. Zhang, e18 (MFLU 11-1044), living culture MFLUCC 11-0299.

Notes - Acrodictys porosiseptata was initially collected from dead stem of Bambusa sp. in China (Zhao et al. 2011). Xia et al. (2017) recollected this species from dead branches of an unidentified bamboo and provided sequence data. Our new collection MFLUCC 11-0299 has slightly shorter conidia than the holotype $(20-26 \times 12.5-14 \mu \mathrm{m}$ vs. $25-30 \times 13.5-16.5 \mu \mathrm{m})$, but has overlapping conidial size $(20-26 \times 12.5-14 \mu \mathrm{m}$ vs. $20-36.5 \times 13.5-15.5 \mu \mathrm{m})$ with collections of 
Xia et al. (2017). MFLUCC 11-0299 has identical LSU and ITS sequence data with $A$. porosiseptata HSAUP H4698, and phylogenetic analysis also supports them to be the same species (Fig. 1). This is a new geographical and habitat record of A. porosiseptata from freshwater in Thailand.

Junewangiaceae J.W. Xia \& X.G. Zhang, Scientific Reports 7(no. 7888): 12 (2017)

Type genus - Junewangia W.A. Baker \& Morgan-Jones

Notes - Junewangiaceae was established to accommodate a single genus Junewangia, characterized by macronematous, cylindrical conidiophores, monoblastic conidiogenous cells with narrow or flaring collarette, and oval, ellipsoidal to spherical conidia (Xia et al. 2017). Other two genera, Dictyosporella and Sporidesmiella, were later included in the family based on multigene analyses (Luo et al. 2019). Sporidesmiella differs from other genera in having long conidiophores without collarette, and cuneate to obovoid conidia with fewer septa (Kirk 1982, Luo et al. 2019). Dictyosporella and Junewangia have muriform conidia, but the latter differs in having long conidiophores (Ariyawansa et al. 2015, Xia et al. 2017, Song et al. 2018a). Hyde et al. (2020) referred Sporidesmiella to Diaporthomycetidae genera incertae sedis because Sporidesmiella clustered in a separated clade with Junewangiaceae. However, in our phylogenetic analysis, the three genera Dictyosporella, Junewangia and Sporidesmiella constitute a well-supported clade with strong ML and BYPP bootstrap support (Fig. 1), which is accordant with Luo et al. (2019). Thus, we accept these three genera in Junewangiaceae. The family placement of Junewangiaceae is undetermined and referred to Diaporthomycetidae genera incertae sedis in this study.

Dictyosporella Abdel-Aziz, Fungal Diversity 75: 143 (2015)

Type species - Dictyosporella aquatica Abdel-Aziz

Notes - Dictyosporella was introduced for an aquatic hyphomycetous species $D$. aquatica that is characterized by dictyoseptate conidia which are helicoid when young and becoming masses of cells at maturity (Ariyawansa et al. 2015). Other three asexual species, i.e. D. ellipsoidea, D. guizhouensis and $D$. hydei, also have dictyoseptate conidia, but they are not helicoid when young (Song et al. 2018a, Yuan et al. 2020, this study). Dictyosporella ellipsoidea and D. guizhouensis have separating cells at the conidial base, while the other two species D. aquatica and D. hydei lack this structure.

Dictyosporella is polyphyletic as shown in our phylogenetic tree (Fig. 1). Dictyosporella aquatica clusters with D. guizhouensis and other two sexual species D. chiangmaiensis and D. thailandensis in a well-supported clade (Fig. 1). While, Dictyosporella hydei clusters with Junewangia aquatica and D. ellipsoidea clusters with Junewangia sphaerospora in a separated clade, which is distant from the type species D. aquatica.

Dictyosporella hydei cannot be placed in Junewangia because of the absence of macronematous conidiophores and conidiogenous cells with narrow or flaring collarette (Song et al. 2018a). Only LSU sequence data is available for $D$. hydei, which has one nucleotide diference with J. aquatica. Dictyosporella hydei differs from J. aquatica in having micronematous, closely packed conidiophores without percurrent proliferations, and larger, globose to broadly cylindrical conidia $(22-50 \times 15-26 \mu \mathrm{m}$ vs. $17-20 \times 14-18 \mu \mathrm{m})$ comprising multiple angular, subglobose cells (Song et al. 2018a, b). Dictyosporella ellipsoidea also morphologically does not belong in Junewangia due to its its sporodochial, punctiform colonies, dictyoseptate conidia with a separating cell, and lacking a macronematous conidiophore with percurrent proliferations (see notes under D. ellipsoidea). The relationships between the two genera Dictyosporella and Junewangia are unclear until evidence is obtained in future.

The sexual morph of Dictyosporella, D. thailandensis, was introduced based on molecular data, and characterized by annulatascaceae-like characteristics: immersed ascomata with neck erumpent through host substrate, cylindrical asci with a long pedicel and small, refractive, wedgeshaped apical ring, and fusiform, hyaline, 3-septate ascospores with filamentous bipolar appendages (Zhang et al. 2017). In this study, we introduce one new sexual morph (D. 
chiangmaiensis) and one new asexual morph (D. ellipsoidea) in the genus and provide a new collection for D. guizhouensis.
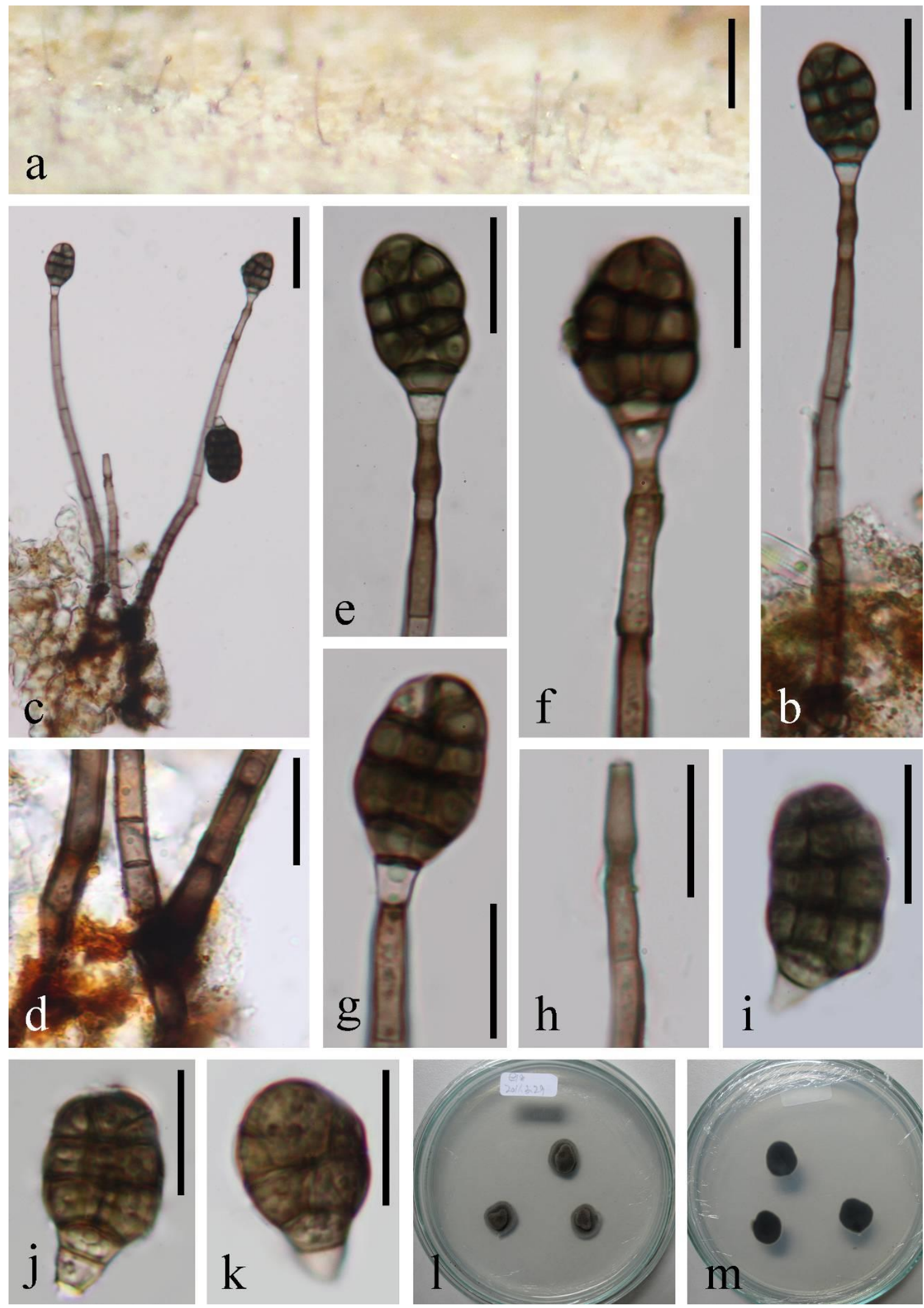

Figure 19 - Acrodictys porosiseptata (MFLU 11-1044), a Colonies on submerged wood. $\mathrm{b}$, c Conidiophores with conidia. d Bases of conidiophores. e-g Conidiogenous cells with conidia. $\mathrm{h}$ Upper part of conidiophore showing proliferations. i-k Conidia. 1, m Colony on PDA (left-front, right-reverse). Scale bars: $\mathrm{a}=150 \mu \mathrm{m}, \mathrm{b}, \mathrm{d}-\mathrm{k}=15 \mu \mathrm{m}, \mathrm{c}=30 \mu \mathrm{m}$. 
Dictyosporella chiangmaiensis X.D. Yu, W. Dong \& H. Zhang, sp. nov.

Fig. 20

Index Fungorum number: IF558043; Facesoffungi number: FoF 09559

Etymology - in reference to Chiang Mai, from where the holotype was collected

Holotype - MFLU 17-1707

Saprobic on submerged wood in freshwater. Sexual morph: Ascomata 170-200 $\mu \mathrm{m}$ high, 105-140 $\mu \mathrm{m}$ diam., scattered to gregarious, immersed with neck erumpent through host surface, ovoid to pyriform, brown, coriaceous, ostiolate, with a central neck. Necks short, hyaline to pale brown, cylindrical, upright to the substrate surface, often covered with a mass of white spores. Peridium 10-15 $\mu \mathrm{m}$ thick, comprising several layers of brown to hyaline, thick-walled, compressed cells of textura porrecta. Paraphyses up to $3.5 \mu \mathrm{m}$ diam. at the base, tapering towards the apex, dense, hypha-like, septate, constricted at septa, unbranched, hyaline. Asci 113-138 $\times 13-15 \mu \mathrm{m}(\bar{x}$ $=125 \times 14 \mu \mathrm{m}, \mathrm{n}=10), 8$-spored, unitunicate, narrowly clavate to fusiform, slightly tapering and rounded at apex, pedicellate, with an indistinct, small, refractive, wedge-shaped, apical ring, 1.7$2.2 \times 2-4 \mu \mathrm{m}$. Ascospores $16-24.5 \times 6.5-8.7 \mu \mathrm{m}(\bar{x}=20.5 \times 7.5 \mu \mathrm{m}, \mathrm{n}=30)$, uni- to bi-seriate, mostly broadly clavate, sometimes fusiform, straight or slightly curved, 3-septate, constricted at septa, the second cell often larger than others, guttulate, hyaline, thin-walled, smooth, without mucilaginous sheath. Asexual morph: Undetermined.

Material examined - Thailand, Chiang Mai Province, on submerged wood in a stream, 1 September 2017, X.D. Yu, 22A (MFLU 17-1707, holotype), ex-type living culture MFLUCC 172345 .

Notes - Dictyosporella chiangmaiensis clusters with D. thailandensis with high bootstrap support (Fig. 1). Dictyosporella chiangmaiensis is similar to D. thailandensis in having immersed ascomata with a subhyaline neck erumpent through host substrate, asci with a small apical ring and hyaline, 3-septate ascospores (Zhang et al. 2017). However, D. chiangmaiensis has broadly clavate ascospores with larger second cells and without appendages. In contrast, D. thailandensis has fusiform ascospores with bipolar filamentous appendages (Zhang et al. 2017). Phylogenetic analysis also supports $D$. chiangmaiensis to be a new species in the genus.

Dictyosporella ellipsoidea W. Dong, H. Zhang \& K.D. Hyde, sp. nov.

Fig. 21

Index Fungorum number: IF558044; Facesoffungi number: FoF 09560

Etymology - in reference to mostly ellipsoidal conidia of this fungus

Holotype - MFLU 18-1209

Saprobic on submerged wood in freshwater. Sexual morph: Undetermined. Asexual morph: Hyphomycetous. Colonies sporodochial, punctiform, gregarious or scattered, raised, black. Mycelium partly immersed, partly superficial on substratum, consisting of septate, thin-walled, hyaline hyphae. Conidiophores mostly absent or reduced to conidiogenous cells. Conidiogenous cells 5.5-12 × 3-4.5 $\mu \mathrm{m}(\bar{x}=8.5 \times 3.7 \mu \mathrm{m}, \mathrm{n}=5)$, holoblastic, monoblastic, integrated, determinate, terminal, subcylindrical, hyaline, smooth. Separating cells 8-15 $\times 6.5-12.5 \mu \mathrm{m}$, inflated cylindrical, wedge-shaped or irregular, hyaline, smooth, thin-walled. Conidia 30-46 $\times$ 17.5-28.5 $\mu \mathrm{m}(\bar{x}=36 \times 22 \mu \mathrm{m}, \mathrm{n}=35)$, acrogenous, solitary, dry, thin-walled, smooth-walled, ellipsoidal to broadly clavate, subglobose, or irregular-shaped, dictyoseptate, slightly constricted at septa, brown to dark brown, with a truncate base.

Culture characteristics - On PDA, colony irregular, reaching $10 \mathrm{~mm}$ in 15 days at $25^{\circ} \mathrm{C}$, dark grey from above, black from below, surface wrinkled, dry, with dense mycelium, raised, undulate at edge.

Material examined - China, Yunnan Province, Dehong City, on submerged wood in a stream, 25 November 2017, G.N. Wang, H158A (MFLU 18-1209, holotype), ex-type living culture MFLUCC 18-1042; ibid., HKAS 101741, isotype, ex-isotype living culture KUMCC 18-0093.

Notes - In our phylogenetic analysis, our collection MFLUCC 18-1042 clusters in Junewangia with good bootstrap support (Fig. 1). However, MFLUCC 18-1042 morphologically belongs in Dictyosporella due to the sporodochial, punctiform colonies, dictyoseptate conidia with a separating cell and without macronematous conidiophores (Song et al. 2018a, Yuan et al. 2020). 
Whereas, Junewangia is characterized by effuse, hairy colonies, macronematous, long conidiophores with slightly flaring collarette and percurrent proliferations, and oval to subspherical conidia with several oblique septa and a protuberant, truncate basal cell (Baker et al. 2002). Therefore, we identify our collection as a new species in Dictyosporella, namely D. ellipsoidea.

Dictyosporella ellipsoidea differs from other Dictyosporella asexual species, i.e. D. aquatica, D. hydei and D. guizhouensis, in having mostly ellipsoidal conidia with an inflated cylindrical, wedge-shaped or irregular separating cell.
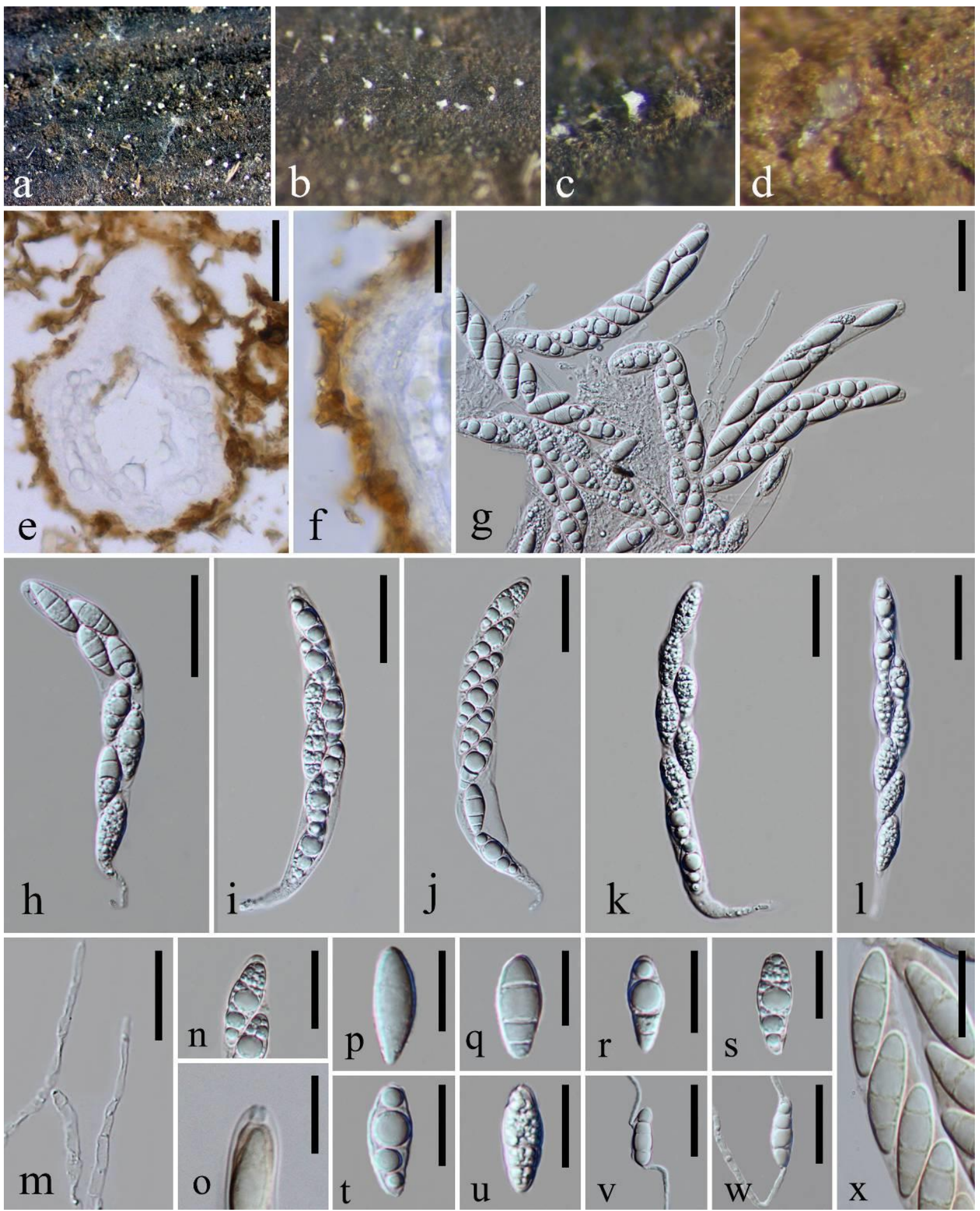

Figure 20 - Dictyosporella chiangmaiensis (MFLU 17-1707, holotype), a-d Appearance of ascomatal necks on host. e Vertical section of ascoma. f Structure of peridium. g-1 Unitunicate asci. $\mathrm{m}$ Paraphyses. n, o Apical rings (o in melzer's reagent). $\mathrm{p}-\mathrm{u}$ Ascospores in water. $\mathrm{x}$ Ascospores in 
melzer's reagent. $\mathrm{v}, \mathrm{w}$ Germinated ascospores. Scale bars: $\mathrm{e}=50 \mu \mathrm{m}, \mathrm{f}, \mathrm{n}, \mathrm{w}=20 \mu \mathrm{m}, \mathrm{g}-1, \mathrm{v}=30$ $\mu \mathrm{m}, \mathrm{m}, \mathrm{o}-\mathrm{u}, \mathrm{x}=15 \mu \mathrm{m}$.
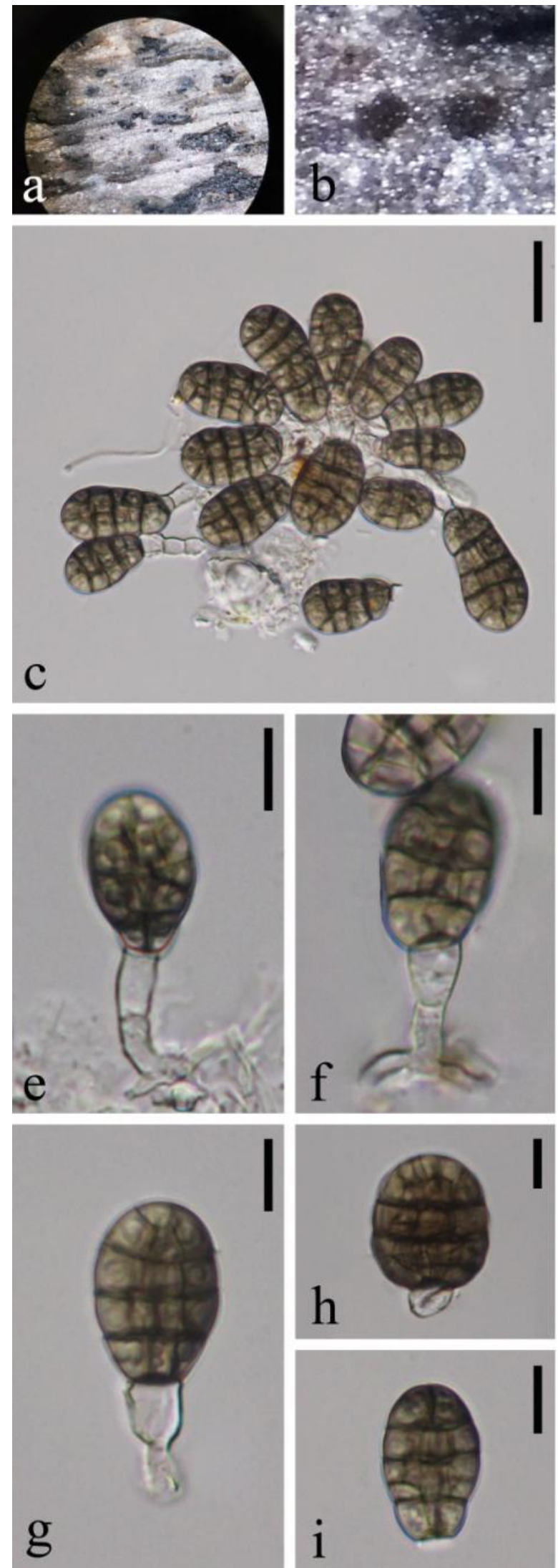
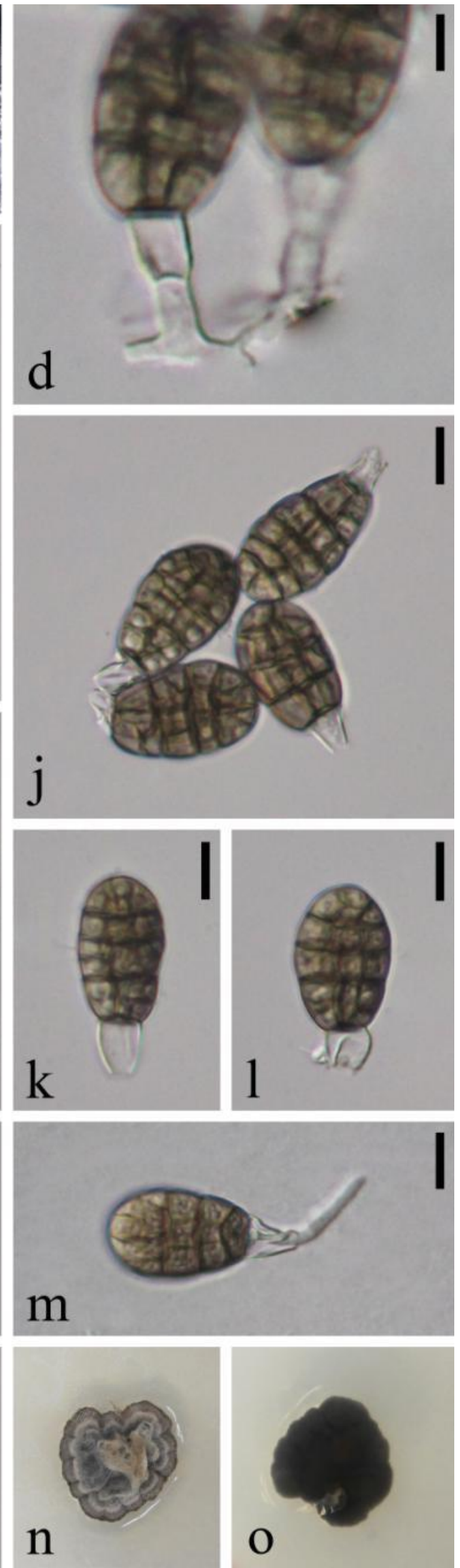

Figure 21 - Dictyosporella ellipsoidea (MFLU 18-1209, holotype). a, b Colonies on submerged wood. $\mathrm{c}-\mathrm{f}$ Conidiogenous cells with conidia. g-l Conidia. $\mathrm{m}$ Germinated conidium. $\mathrm{n}$, o Colony on PDA (left-front, right-reverse). Scale bars: $\mathrm{c}=20 \mu \mathrm{m}, \mathrm{d}=5 \mu \mathrm{m}, \mathrm{e}-\mathrm{m}=10 \mu \mathrm{m}$. 
Saprobic on submerged wood in freshwater. Sexual morph: Undetermined. Asexual morph: Hyphomycetous. Colonies sporodochial, punctiform, gregarious or scattered, raised, black. Mycelium partly immersed, partly superficial on substratum, consisting of septate, thin-walled, hyaline hyphae. Conidiophores absent or reduced to conidiogenous cells. Conidiogenous cells holoblastic, monoblastic, integrated, determinate. Separating cells 6-28 $\times 6-10 \mu \mathrm{m}(\bar{x}=15 \times 8$ $\mu \mathrm{m}, \mathrm{n}=10$ ), subglobose, ellipsoidal, or irregular-shaped, aseptate, sometimes 1-2-septate, hyaline, smooth, thin-walled. Conidia 15-24 $\times 11-17 \mu \mathrm{m}(\bar{x}=19 \times 14 \mu \mathrm{m}, \mathrm{n}=35)$, acrogenous, solitary, dry, thin-walled, smooth-walled, oblate ellipsoidal, subglobose, or irregular-shaped, dictyoseptate, constricted at septa, pale brown to dark brown, with a rounded or truncate base.

Culture characteristics - On PDA, colony circular, reaching $5 \mathrm{~mm}$ in 7 days at $25^{\circ} \mathrm{C}$, reddish brown to white from above, yellowish brown from below, surface rough, dry, with dense mycelium, raised, entire at edge.

Material examined - China, Yunnan Province, Dehong City, on submerged wood in a stream, 25 November 2017, G.N. Wang, H3B (MFLU 18-1179), living culture MFLUCC 18-1232; ibid., HKAS 101727, living culture KUMCC 18-0077.

Notes - Our new collection MFLUCC 18-1232 clusters with Dictyosporella guizhouensis MFLU 18-1505 with high bootstrap support (Fig. 1). They have identical LSU sequence data and seven (including one gap) nucleotide differences in ITS sequence data between MFLUCC 18-1232 and MFLU 18-1505. No protein coding genes can be compared. MFLUCC 18-1232 has very similar morphological characteristics and overlapping conidial size with the holotype of $D$. guizhouensis (Yuan et al. 2020). Based on multigene analysis, single gene comparison and their similar morphological characteristics, we identify our collection as D. guizhouensis.

Junewangia W.A. Baker \& Morgan-Jones, Mycotaxon 81: 307 (2002)

Type speices - Junewangia sphaerospora W.A. Baker \& Morgan-Jones

Notes - Junewangia was introduced to accommodate the species having macronematous, mononematous conidiophores with slightly flaring collarette and percurrent proliferations, and oval to subspherical conidia with several oblique septa and a protuberant, truncate basal cell (Baker et al. 2002). Xia et al. (2017) provided sequence data for three species, i.e. J. lamma, J. queenslandica and $J$. sphaerospora (type), and establish a new family Junewangiaceae to accommodate Junewangia. Except for J. obliqua, all Junewangia species have sequence data in GenBank. Junewangia is shown to be polyphyletic as Junewangia species cluster with Dictyosporella hydei and D. ellipsoidea in two separated clades (Fig. 1). The polyphyletic nature of Junewangia needs to be resolved with more collections and DNA sequence data. We introduce a new species in Junewangia, which was collected from submerged wood in freshwater in Thailand.

Junewangia thailandica W. Dong, H. Zhang \& K.D. Hyde, sp. nov.

Fig. 23

Index Fungorum number: IF558045; Facesoffungi number: FoF 09561

Etymology - in reference to the host location, Thailand, where the holotype was collected

Holotype - MFLU 15-2682

Saprobic on submerged wood in freshwater. Sexual morph: Undetermined. Asexual morph: Hyphomycetous. Colonies superficial, effuse, gregarious, hairy, brown. Mycelium mostly immersed, composed of septate, branched, pale brown, thin-walled hyphae. Conidiophores 70-195 $\times 4-5.5 \mu \mathrm{m}(\bar{x}=120 \times 4.5 \mu \mathrm{m}, \mathrm{n}=10)$, macronematous, mononematous, erect, cylindrical, straight or slightly flexuous, septate, slightly constricted and flaring at septa, swollen at the base, unbranched, brown, paler towards the apex, smooth. Conidiogenous cells holoblastic, monoblastic, integrated, determinate, terminal, subcylindrical, pale brown, smooth, with 3-7 successive percurrent proliferations. Conidia $22-32.5 \times 16.5-23 \mu \mathrm{m}(\bar{x}=26 \times 19.5 \mu \mathrm{m}, \mathrm{n}=20)$, acrogenous, solitary, dry, thin-walled, smooth-walled, broadly ellipsoidal to subglobose, dictyoseptate, with longitudinal, transverse and oblique septa, constricted at septa, pale brown to dark brown, guttulate, 
with a protruding basal cell; basal cells $2.4-4.2 \times 3-5 \mu \mathrm{m}(\bar{x}=3.2 \times 4.4 \mu \mathrm{m}, \mathrm{n}=10)$, wedgeshaped or subcylindrical, truncate, pale brown to subhyaline.
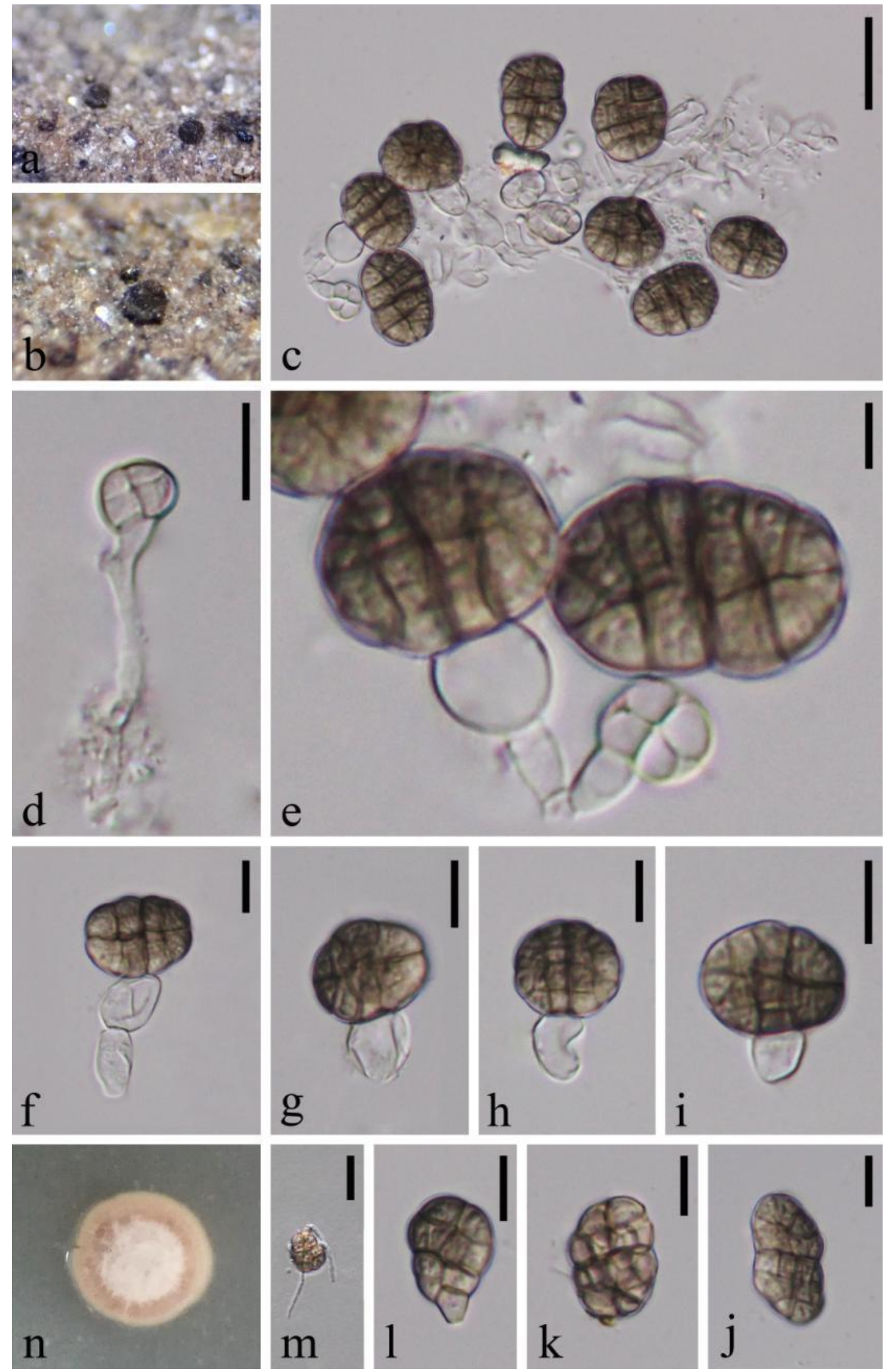

Figure 22 - Dictyosporella guizhouensis (MFLU 18-1179, holotype). a, b Colonies on submerged wood. c, e-1 Conidia. d Conidiogenous cell with immature conidium. m Germinated conidium. $\mathrm{n}$ Colony on PDA (from front). Scale bars: $\mathrm{c}, \mathrm{m}=20 \mu \mathrm{m}, \mathrm{d}, \mathrm{f}-\mathrm{l}=10 \mu \mathrm{m}, \mathrm{e}=5 \mu \mathrm{m}$. 

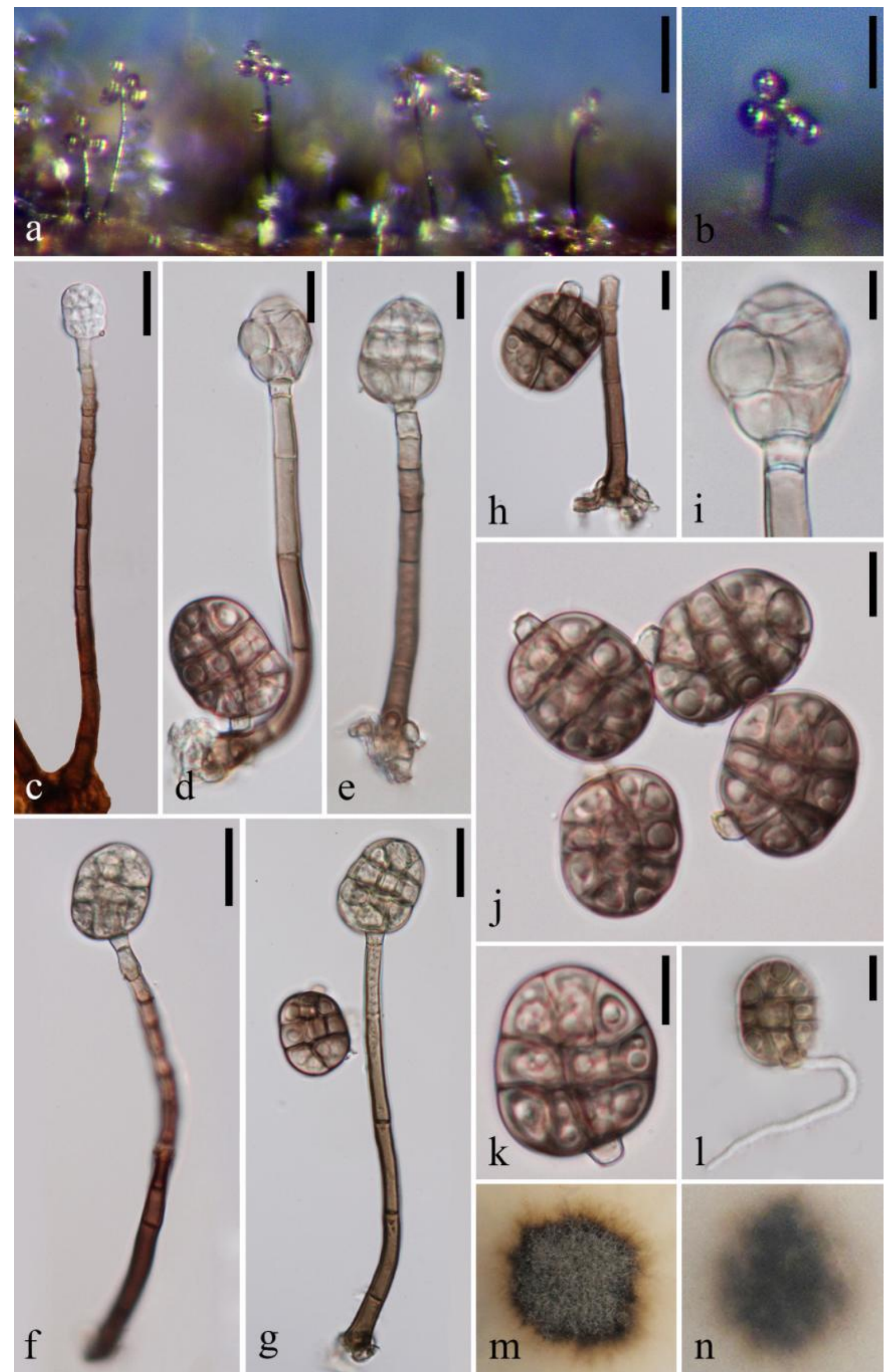

Figure 23 - Junewangia thailandica (MFLU 15-2682, holotype). a, b Colonies on submerged wood. $\mathrm{c}-\mathrm{h}$ Conidiophores with conidia. i Conidiogenous cell with conidium. $\mathrm{j}, \mathrm{k}$ Conidia. 
1 Germinated conidium. m, n Colony on PDA (left-front, right-reverse). Scale bars: $\mathrm{a}=100 \mu \mathrm{m}$, $\mathrm{b}=50 \mu \mathrm{m}, \mathrm{c}, \mathrm{f}, \mathrm{g}=20 \mu \mathrm{m}, \mathrm{d}, \mathrm{e}, \mathrm{h}, \mathrm{j}-\mathrm{l}=10 \mu \mathrm{m}, \mathrm{i}=5 \mu \mathrm{m}$.

Culture characteristics - On PDA, colony circular, slow growing, reaching $5 \mathrm{~mm}$ in 30 days at $25^{\circ} \mathrm{C}$, grey from above, dark grey from below, surface rough, dry, with sparse mycelium, raised, entire at edge.

Material examined - Thailand, Prachuap Khiri Khan Province, on submerged wood in a stream, 30 July 2015, K.D. Hyde, 130A (MFLU 15-2682, holotype).

Notes - Junewangia thailandica forms a distinct branch with all sequenced Junewangia species (Fig. 1). Junewangia thailandica is similar to an unsequenced species J. obliqua in conidial shape, but $J$. thailandica differs in having longer conidiophores (up to $195 \mu \mathrm{m}$ vs. up to $120 \mu \mathrm{m}$ ) and conidial septa (mostly longitudinal, transverse and sometimes oblique septa in J. thailandica vs. numerous oblique septa in J. obliqua) (Baker et al. 2002). Thus, we introduce Junewangia thailandica sp. nov. in this study.

Sporidesmiella P.M. Kirk, Trans. Br. mycol. Soc. 79(3): 479 (1982)

Type species - Sporidesmiella claviformis P.M. Kirk

Notes - Due to the heterogeneous characteristics of Sporidesmium, Sporidesmiella was proposed for species having cuneate to obovoid conidia with fewer septa (Kirk 1982). Sporidesmiella comprises almost 50 epithets in Index Fungorum (2021). It has been shown to be polyphyletic as S. fusiformis clusters in Melanommataceae (Dothideomycetes) (Shenoy et al. 2006), while $S$. aquatica, $S$. hyalosperma and $S$. novae-zelandiae cluster in Junewangiaceae (Sordariomycetes) (Luo et al. 2019). Molecular data of the type species S. claviformis is needed to resolve the polyphyletic nature. Sporidesmium has been phylogenetically linked to two sexual morphs, S. lignicola and S. thailandense, which are morphologically similar to Annulatascaceae (Zhang et al. 2017, Luo et al. 2019), while the sexual morph of Sporidesmiella is undetermined. In this study, we introduce a new asexual species in Sporidesmiella based on phylogenetic analysis (Fig. 1), a key provided by $\mathrm{Ma}$ et al. (2012) and the recent literature. A new collection of $S$. hyalosperma from freshwater in China is also provided.

Sporidesmiella hyalosperma (Corda) P.M. Kirk, Trans. Br. mycol. Soc. 79(3): 481 (1982)

Fig. 24

Saprobic on submerged wood in freshwater. Sexual morph: Undetermined. Asexual morph: Hyphomycetous. Colonies superficial, effuse, gregarious, hairy, pale brown. Mycelium mostly immersed, composed of septate, branched, pale brown, thin-walled hyphae. Conidiophores $90-110$ $\times 3.5-4.7 \mu \mathrm{m}(\bar{x}=103 \times 4 \mu \mathrm{m}, \mathrm{n}=10)$, macronematous, mononematous, erect, cylindrical, straight or slightly flexuous, septate, slightly constricted at septa, robust at the base, unbranched, pale brown to brown, paler towards the apex, smooth. Conidiogenous cells 35-48 $\times 4-4.5 \mu \mathrm{m}(\bar{x}=$ $42 \times 4.2 \mu \mathrm{m}, \mathrm{n}=5$ ), holoblastic, polyblastic, integrated, with sympodial proliferations, terminal, cylindrical, brown, smooth. Conidia 18.5-25 ×8-10.5 $\mu \mathrm{m}(\bar{x}=21 \times 9.5 \mu \mathrm{m}, \mathrm{n}=20)$, acrogenous, pleuroacrogenous, solitary, dry, thin-walled, smooth-walled, obovoid or broadly clavate, subcylindrical, (3-)4-distoseptate, olivaceous brown, with a truncate base and faintly pigmented scar.

Culture characteristics - On PDA, colony circular, reaching $15 \mathrm{~mm}$ in 30 days at $25^{\circ} \mathrm{C}$, reddish brown from above and below, surface rough, dry, with dense mycelium, raised, entire at edge.

Material examined - China, Yunnan Province, Pingbian City, on submerged wood in a stream, 20 September 2017, W. Dong, WF1A (MFLU 18-1200), living culture MFLUCC 18-1013; ibid., HKAS 101705, living culture KUMCC 18-0054.

Notes - Sporidesmiella hyalosperma was first published in 1837 and named as Helminthosporium hyalospermum (Index Fungorum 2021). The current name S. hyalosperma proposed by Kirk (1982) is widely used for modern classification since its sequence data was 
obtained from a freshwater collection (Luo et al. 2019). Our new collection MFLUCC 18-1013 has shorter conidiophores $(90-110 \times 3.5-4.7 \mu \mathrm{m}$ vs. $116-144 \times 5-7 \mu \mathrm{m})$ than collections of Luo et al. (2019) and slightly thinner conidia $(18.5-25 \times 8-10.5 \mu \mathrm{m}$ vs. $22-26 \times 12-14.5 \mu \mathrm{m})$ than those of Kirk (1982). Kirk (1982) described monoblastic conidiogenous cells in S. hyalosperma, while Luo et al. (2019) and our study found polyblastic conidiogenous cells. Multigene phylogenetic analysis and base pair comparison support our collection to be S. hyalosperma (Fig. 1).

Sporidesmiella obovoidia X.D. Yu, W. Dong \& H. Zhang, sp. nov.

Fig. 25

Index Fungorum number: IF558078; Facesoffungi number: FoF 09562

Etymology - in reference to obovoid conidia of the fungus

Holotype - MFLU 17-1731

Saprobic on submerged wood in freshwater. Sexual morph: Undetermined. Asexual morph: Hyphomycetous. Colonies superficial, effuse, gregarious, hairy, dark brown to black. Mycelium mostly immersed, composed of septate, branched, pale brown, thin-walled hyphae. Conidiophores 80-125 $\times 3.5-4.5 \mu \mathrm{m}(\bar{x}=96 \times 4 \mu \mathrm{m}, \mathrm{n}=10)$, macronematous, mononematous, erect, cylindrical, straight or flexuous, septate, not constricted at septa, slightly robust at the base, unbranched, brown, smooth. Conidiogenous cells $10-40 \times 3-4 \mu \mathrm{m}(\bar{x}=27 \times 3.7 \mu \mathrm{m}, \mathrm{n}=10)$, holoblastic, polyblastic, integrated, with sympodial proliferations, terminal and intercalary, cylindrical, brown, smooth. Conidia 20-25 $\times 9-11.5 \mu \mathrm{m}(\bar{x}=22 \times 10 \mu \mathrm{m}, \mathrm{n}=20)$, acrogenous, pleuroacrogenous, solitary, dry, thin-walled, smooth-walled, mostly obovoid, or broadly clavate, (3-)4-distoseptate, brown or olivaceous brown, often with some small, sub-rounded hollows in each cell, with a truncate base and faintly pigmented scar.

Culture characteristics - On PDA, colony circular, reaching $20 \mathrm{~mm}$ in 25 days at $25^{\circ} \mathrm{C}$, greydark brown from above, black from below, surface rough, dry, with dense mycelium, umbonate, entire at edge.

Material examined - Thailand, Chiang Mai Province, Mushroom Research Centre, on submerged wood in a stream, 1 September 2017, X.D. Yu, 21A (MFLU 17-1731, holotype), extype living culture MFLUCC 17-2372.

Notes - Sporidesmiella obovoidia clusters with S. hyalosperma with strong bootstrap support (Fig. 1). Sporidesmiella obovoidia is similar to S. hyalosperma in having polyblastic conidiogenous cells with sympodial proliferations, and obovoid, 3-4-distoseptate, brown conidia (Luo et al. 2019). However, $S$. obovoidia differs in having longer conidia $(20-25 \times 9-11.5 \mu \mathrm{m}$ vs. $17-21 \times 8-10 \mu \mathrm{m})$. In addition, $S$. obovoidia often has some small, sub-rounded hollows in each cell, which are not observed in $S$. hyalosperma. A nucleotide comparison between $S$. obovoidia and S. hyalosperma shows a difference of 7, 23 and 12 nucleotides in LSU, ITS and TEF sequence data, respectively, which supports them to be different species (Jeewon \& Hyde 2016).

Papulosaceae Winka \& O.E. Erikss., Mycoscience 41(2): 102 (2000)

Type genus - Papulosa Kohlm. \& Volkm.-Kohlm.

Notes - Papulosaceae was established by Winka \& Eriksson (2000) to accommodate a single genus Papulosa with $P$. amerospora as the type species. Currently, four genera, viz. Brunneosporella, Fluminicola, Papulosa and Wongia, are accepted in Papulosaceae based on multigene analyses (Khemmuk et al. 2016, Luo et al. 2019, Hyde et al. 2020, this study, Fig. 1). Platytrachelon was placed in Papulosaceae by Zhang et al. (2017), but not accepted by Luo et al. (2019), and recently was referred to Diaporthomycetidae genera incertae sedis (Hyde et al. 2020). Papulosaceae is one of the families to accommodate annulatascaceae-like taxa Fluminicola, which is characterized by cylindrical asci with a relatively small, discoid apical ring and hyaline, fusiform ascospores (Zhang et al. 2017). These characteristics can be easily distinguished from the other three genera in the family. 

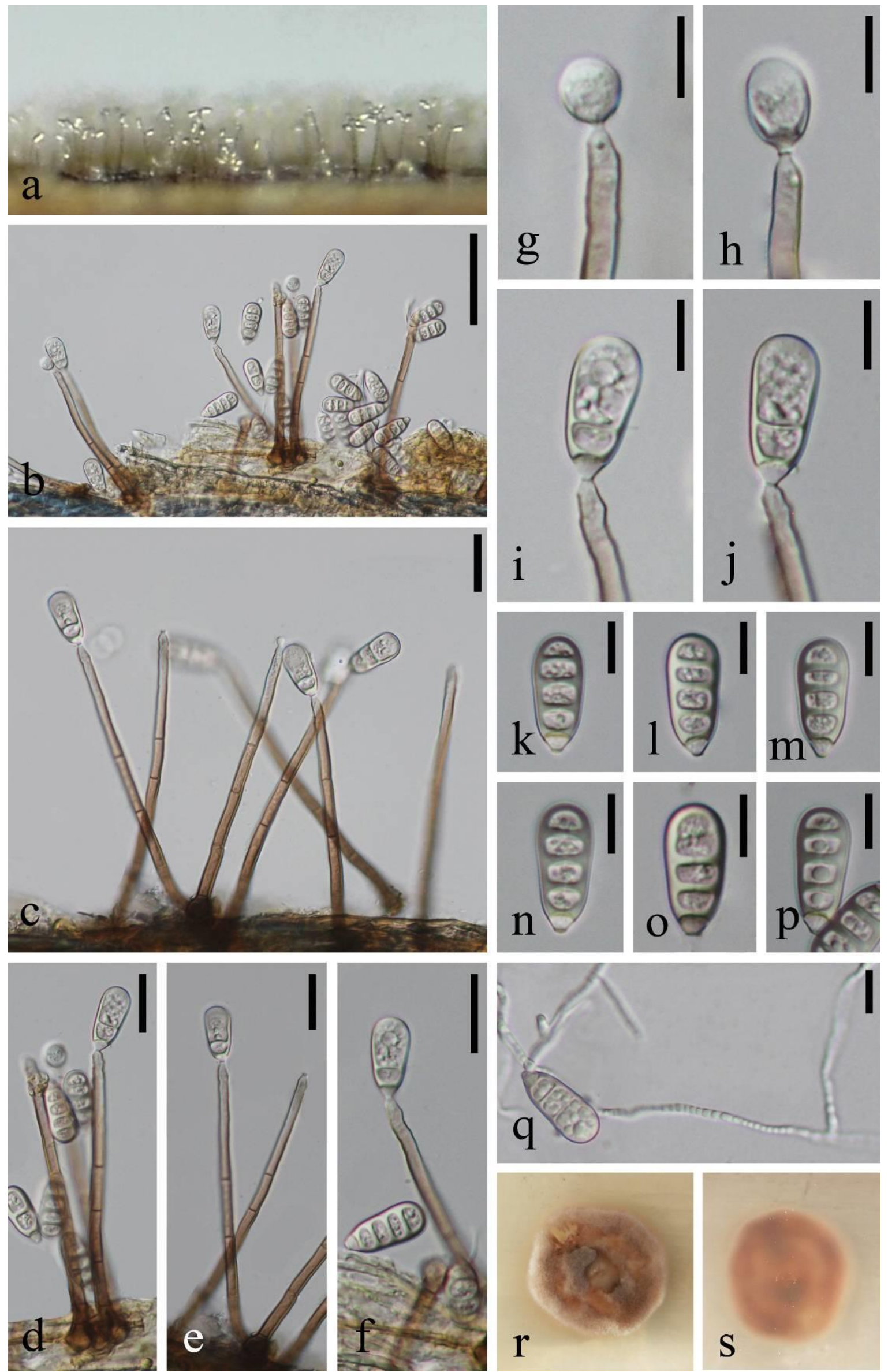

Figure 24 - Sporidesmiella hyalosperma (MFLU 18-1200). a Colonies on submerged wood. $\mathrm{b}-\mathrm{f}$ Conidiophores, conidiogenous cells and conidia. $\mathrm{g}-\mathrm{j}$ Conidiogenous cells with conidia. 
k-p Conidia. q Germinated conidium. r, s Colony on PDA (left-front, right-reverse). Scale bars: $b=$ $50 \mu \mathrm{m}, \mathrm{c}-\mathrm{f}=20 \mu \mathrm{m}, \mathrm{g}-\mathrm{q}=10 \mu \mathrm{m}$.
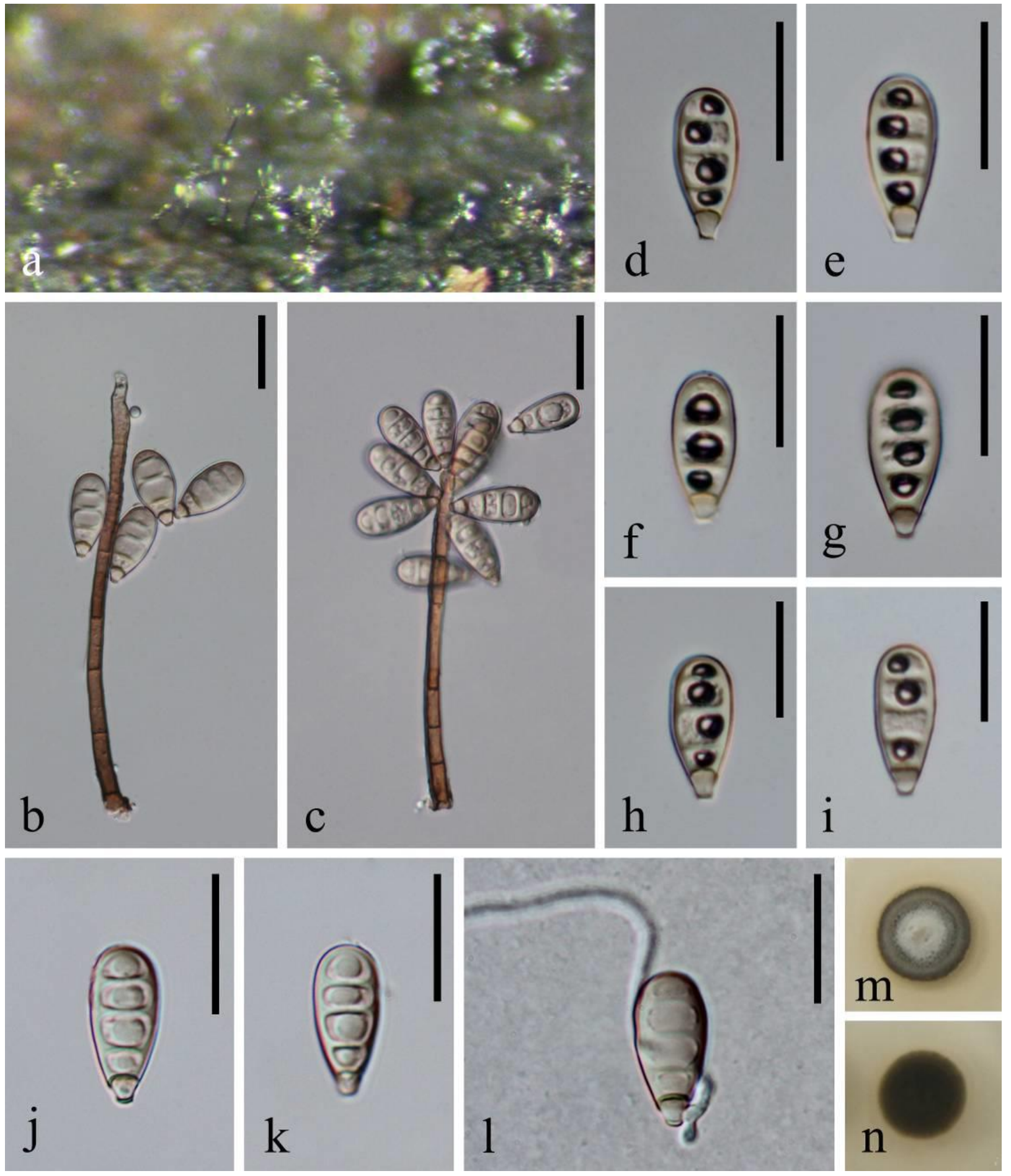

Figure 25 - Sporidesmiella obovoidia (MFLU 17-1731, holotype). a Colonies on submerged wood. b, c Conidiophores with conidia. $\mathrm{d}-\mathrm{k}$ Conidia ( $\mathrm{d}-\mathrm{i}$ note the dark ornamentations on the surface). 1 Germinated conidium. m, n Colony on PDA (up-front, down-reverse). Scale bars: $b-1=20 \mu \mathrm{m}$.

Fluminicola S.W. Wong, K.D. Hyde \& E.B.G. Jones, Fungal Diversity Res. Ser. 2: 190 (1999) Type species - Fluminicola bipolaris S.W. Wong, K.D. Hyde \& E.B.G. Jones

Notes - Fluminicola was introduced for a freshwater species $F$. bipolaris, and placed in Annulatascaceae based on morphology (Wong et al. 1999b). It is distinctive from other annulatascaceae-like genera in having immersed ascomata with a relatively long, upright neck 
erumpent through host substrate, and irregular bifurcate or cup-like bipolar appendages of ascospores, which are tiny and hyaline and difficult to be observed (Wong et al. 1999b, Zhang et al. 2017). Zhang et al. (2017) transferred Fluminicola to Papulosaceae based on sequence data from their three new species. The sequence data of the type species $F$. bipolaris is lacking and it has been missing for nearly 30 years since it was first collected from Philippines in 1994 (Wong et al. $1999 b)$. Nevertheless, the molecular data of $F$. bipolaris is needed to confirm its generic status in Papulosaceae. In this study, we introduce a new species $F$. striata and synonymize $F$. thailandensis with $F$. saprophytica.

Fluminicola saprophytica W. Dong, H. Zhang \& K.D. Hyde, Fungal Diversity 85: 100 (2017)

Synonym - Fluminicola thailandensis W. Dong, H. Zhang \& K.D. Hyde, Fungal Diversity 85: 100 (2017)

Saprobic on submerged wood in freshwater. Sexual morph: Ascomata 80-120 $\mu \mathrm{m}$ high, 220 $250 \mu \mathrm{m}$ diam., scattered to gregarious, immersed with neck erumpent through host substrate, compressed ellipsoidal, black, coriaceous, ostiolate, with a lateral neck. Necks relatively long, black, cylindrical, upright, periphysate. Peridium 10-30 $\mu \mathrm{m}$ thick, comprising 5-7 layers of thinwalled, large cells of textura angularis, dark brown to black in outer layer, inwardly pale brown to hyaline, poorly developed and flattened at the base, composed of 2-3 layers of pale brown to hyaline, thin-walled, compressed cells of textura angularis. Paraphyses cylindrical, unbranched, hyaline, septate. Asci $95-120 \times 8.8-13 \mu \mathrm{m}(\bar{x}=110 \times 10.5 \mu \mathrm{m}, \mathrm{n}=15), 8$-spored, unitunicate, cylindrical, apex rounded, long or short pedicellate, with a relatively small, refractive, discoid, apical ring. Ascospores 15-20 $\times$ 4.5-7 $\mu \mathrm{m}(\bar{x}=17 \times 6 \mu \mathrm{m}, \mathrm{n}=20)$, overlapping uniseriate, fusiform, straight, obscurely 3-septate, guttulate, hyaline, thin-walled, smooth, often with bipolar cap-like or bifurcate appendages which are obvious in Indian Ink, sometimes with a thin mucilaginous sheath. Asexual morph: Undetermined.

Culture characteristics - On PDA, colony circular, reaching $15 \mathrm{~mm}$ in 12 days at $25^{\circ} \mathrm{C}$, white-yellowish brown from above, dark brown from below, surface rough, dry, with dense mycelium, raised, entire at edge.

Material examined - Thailand, Satun Province, on submerged wood in a stream, 10 May 2018, W. Dong, hat287 (MFLU 18-1567), living culture MFLUCC 18-1244; ibid., HKAS 105019, KUMCC 19-0035.

Notes - Fluminicola saprophytica was introduced by Zhang et al. (2017) and distinguished to its phylogenetically closest species $F$. thailandensis by shorter asci and thinner ascospores. Luo et al. (2019) identified another two collections as $F$. thailandensis. A nucleotide comparison shows that five strains including our new strain MFLUCC 18-1244 have nearly identical sequence data (Table 2), which indicate that they are conspecific (Jeewon \& Hyde 2016). Multigene analysis also supports them to be the same species (Fig. 1). Morphologically, they have overlapping dimensions of the asci and ascospores, ranging from $95-193 \times 8-15 \mu \mathrm{m}$ in asci and 14-21 $\times 4.5-9 \mu \mathrm{m}$ in ascospores (Zhang et al. 2017, Luo et al. 2019). The appendages and sheaths of $F$. saprophytica are inconspicuous in the holotype, but they can be seen in our new collection MFLUCC 18-1244 and in Luo et al. (2019). The ascomata of $F$. saprophytica are subglobose and with a central neck in the type collection MFLUCC 15-0976 (Zhang et al. 2017) and another collection MFLUCC 14-0037 (Luo et al. 2019), however, they are compressed ellipsoidal with a lateral neck in our new collection MFLUCC 18-1244. It is likely to be a result of the direction of hand section.

Fluminicola striata X.D. Yu, W. Dong \& H. Zhang, sp. nov.

Fig. 27

Index Fungorum number: IF558079; Facesoffungi number: FoF 09563

Etymology - in reference to the distinctive striations on the ascospores wall

Holotype - MFLU 18-1004 

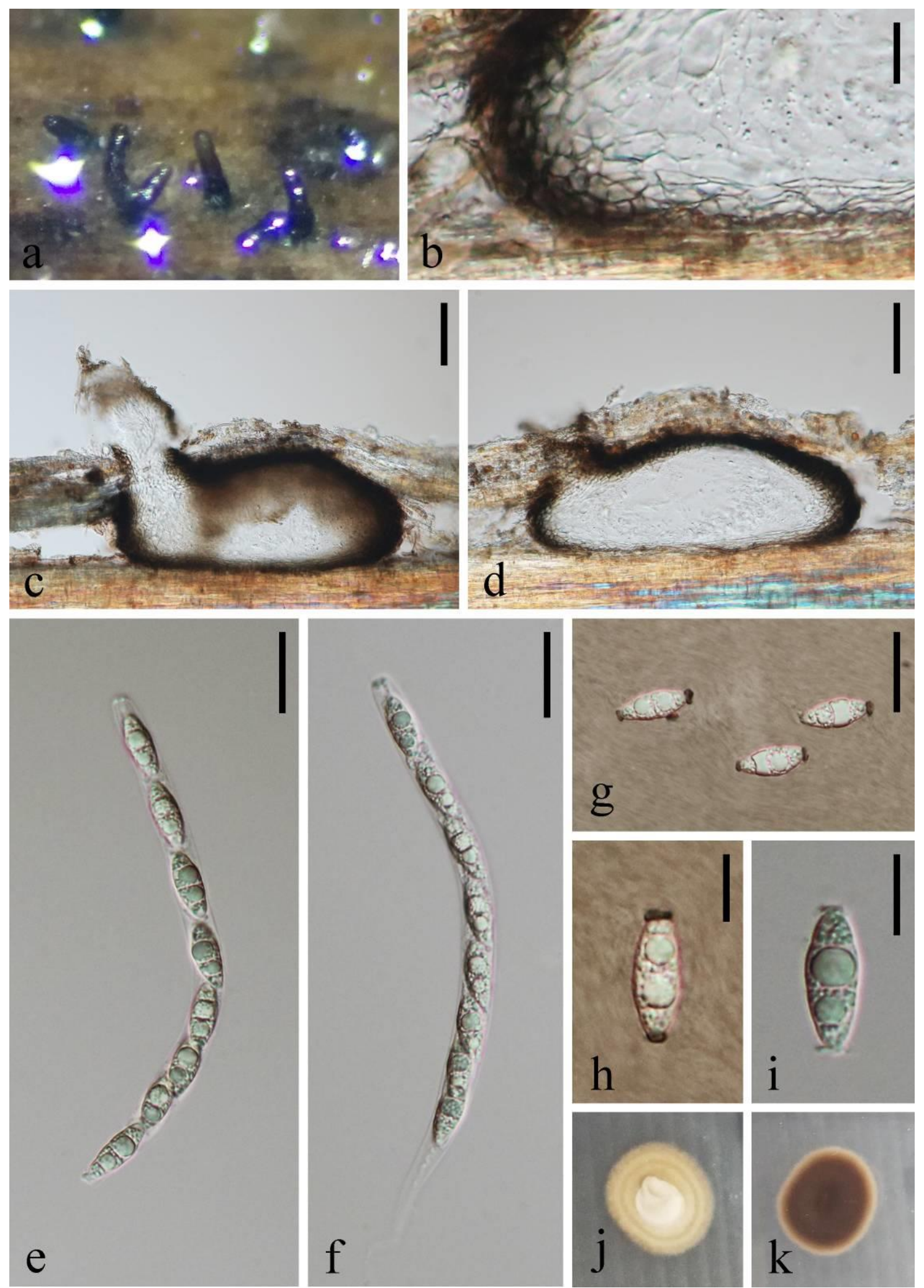

Figure 26 - Fluminicola saprophytica (MFLU 18-1567). a Appearance of necks of ascomata on host. b Structure of peridium. c, d Vertical sections of ascomata. e, $\mathrm{f}$ Unitunicate asci. $\mathrm{g}, \mathrm{h}$ Ascospores in Indian Ink. i Ascospore in water. $\mathrm{j}, \mathrm{k}$ Colony on PDA (left-front, right-reverse). Scale bars: b, h, $\mathrm{i}=10 \mu \mathrm{m}, \mathrm{c}, \mathrm{d}=50 \mu \mathrm{m}, \mathrm{e}-\mathrm{g}=20 \mu \mathrm{m}$.

Saprobic on submerged wood in freshwater. Sexual morph: Ascomata 85-125 $\mu \mathrm{m}$ high, 95$140 \mu \mathrm{m}$ diam., scattered, immersed with neck erumpent through host substrate, subglobose to ellipsoidal, dark brown to black, coriaceous, ostiolate, with a neck. Necks relatively long, 
subhyaline to pale yellowish brown, cylindrical, upright, periphysate. Peridium 20-25 $\mu \mathrm{m}$ thick, comprising several layers of thin-walled, hyaline to brown, compressed cells of textura angularis. Paraphyses sparse or absent. Asci $160-180 \times 10-14 \mu \mathrm{m}(\bar{x}=170 \times 12.5 \mu \mathrm{m}, \mathrm{n}=10), 8$-spored, unitunicate, cylindrical and slightly wider in the middle, apex truncate, short pedicellate, with an indistinct, refractive, relatively small, discoid apical ring, 2-2.5 $\times 3-3.3 \mu \mathrm{m}$. Ascospores $18.5-26.5 \times 5.5-8.7 \mu \mathrm{m}(\bar{x}=22 \times 7 \mu \mathrm{m}, \mathrm{n}=30)$, obliquely uniseriate in the middle of asci, arranged distantly from apical ring, fusiform, with rounded ends, straight, 3-4-septate, not constricted at the septa, guttulate, hyaline, thin-walled, with distinctive striations, sometimes with bipolar bifurcate appendages, without sheath. Asexual morph: Undetermined.

Table 2 Comparison of polymorphic nucleotides for five isolates of Fluminicola saprophytica

\begin{tabular}{|c|c|c|c|c|c|c|c|c|c|c|c|c|c|c|c|c|c|c|c|c|c|c|}
\hline \multirow{2}{*}{ Isolates } & \multicolumn{3}{|c|}{ LSU } & \multicolumn{13}{|l|}{ ITS } & \multicolumn{5}{|c|}{ TEF } & \multirow{2}{*}{ References } \\
\hline & 261 & 423 & 762 & 107 & 108 & 109 & 110 & 142 & 143 & 144 & 170 & 177 & 356 & 489 & 514 & 525 & 97 & 175 & 592 & 673 & 808 & \\
\hline $\begin{array}{l}\text { MFLUCC 15-0976 } \\
\text { (type) }\end{array}$ & $\mathrm{C}$ & $\mathrm{C}$ & $\mathrm{G}$ & $\mathrm{C}$ & $\mathrm{T}$ & $\mathrm{G}$ & $\mathrm{G}$ & $\mathrm{A}$ & $\mathrm{T}$ & $\mathrm{C}$ & $\mathrm{T}$ & $\mathrm{T}$ & $\mathrm{T}$ & $\mathrm{T}$ & $\mathrm{A}$ & - & $\mathrm{C}$ & $\mathrm{G}$ & $\mathrm{C}$ & $\mathrm{C}$ & $\mathrm{C}$ & $\begin{array}{l}\text { Zhang et al. } \\
2017\end{array}$ \\
\hline MFLUCC 15-0984 & $\cdot$ & - & $\cdot$ & • & $\cdot$ & $\cdot$ & $\cdot$ & • & - & $\cdot$ & $\cdot$ & $\mathrm{C}$ & $\mathrm{C}$ & $\mathrm{C}$ & $\mathrm{T}$ & - & \multicolumn{5}{|c|}{ Sequence not available } & $\begin{array}{l}\text { Zhang et al. } \\
2017\end{array}$ \\
\hline MFLUCC 18-1244 & $\mathrm{T}$ & - & - & - & - & - & - & - & - & • & • & $\mathrm{C}$ & $\mathrm{C}$ & $\mathrm{C}$ & $\mathrm{T}$ & $\mathrm{T}$ & $\mathrm{T}$ & A & $\mathrm{T}$ & - & $\mathrm{T}$ & This study \\
\hline MFLUCC 14-0037 & - & $\mathrm{T}$ & - & - & - & - & - & $\mathrm{T}$ & $\mathrm{C}$ & A & $\mathrm{C}$ & $\mathrm{C}$ & $\mathrm{C}$ & $\mathrm{C}$ & $\mathrm{T}$ & $\mathrm{T}$ & & $\cdot$ & $\cdot$ & $\mathrm{G}$ & - & Luo et al. 2019 \\
\hline MFLUCC 18-0199 & . & - & - & \multicolumn{13}{|c|}{ Sequence not available } & \multicolumn{5}{|c|}{ Sequence not available } & Luo et al. 2019 \\
\hline
\end{tabular}

Material examined - Thailand, Phayao Province, on submerged wood in a stream, 23 February 2018, X.D. Yu, Y26 (MFLU 18-1004, holotype), ex-type living culture MFLUCC 18-0990.

Notes - Fluminicola striata is similar to other species in the genus in having immersed ascomata with a neck erumpent through host substrate, cylindrical asci with an indistinct, refractive, relatively small, discoid apical ring, and fusiform, hyaline, septate ascospores with bipolar bifurcate appendages (Zhang et al. 2017). However, F. striata differs in having obvious striations on the ascospore surface. Multigene analysis supports it to be a new species in Fluminicola (Fig. 1).

Pseudoproboscisporaceae H. Zhang, K.D. Hyde \& Maharachch., Fungal Diversity 85: 93 (2017)

Type genus - Pseudoproboscispora Punith.

Notes - Pseudoproboscisporaceae was established to accommodate two annulatascaceae-like genera, Diluviicola and Pseudoproboscispora (Zhang et al. 2017). Pseudoproboscisporaceae differs from other families by ascomata often lying horizontally on the host substrate, with a lateral neck, and fusiform ascospores with bipolar filamentous appendages, which are initially coiled then unfurl to form long threads (Zhang et al. 2017). Pseudoproboscisporaceae was accommodated in Atractosporales based on phylogenetic analysis, morphology and its occurrence in freshwater habitat (Zhang et al. 2017). However, this family was shown to phylogenetically not belong to Atractosporales, and clustered with Junewangiaceae in Luo et al. (2019) and Cancellidium in Hyde et al. (2020). In this study, Pseudoproboscisporaceae forms a sister clade with Junewangiaceae with weak 
bootstrap support (Fig. 1), which concurs with phylogenies reported by Luo et al. (2019). Since Pseudoproboscisporaceae did not cluster consistently with any families in Diaporthomycetidae, we refer it to Diaporthomycetidae families incertae sedis.

Strain HKUCC 3710 bearing the name "Cateractispora recepticuli" clusters in Pseudoproboscisporaceae and it was presumed to be a synonym of Pseudoproboscispora aquatica based on the comparison of photo plate of $C$. recepticuli and P. aquatica (Cai et al. 2006, Zhang et al. 2017). However, HKUCC 3710 (holotype HKU(M) 5239) has been formally published as Cataractispora receptaculorum in $\mathrm{Ho}$ et al. (2004). The ascospore appendages of $C$. receptaculorum are initially in the form of mucilaginous pads and then unfurl readily in water to form long threads and do not coil as a proboscis (Ho et al. 2004). Whereas, appendages of $P$. aquatica are at first coiled, proboscis-like at each end and then uncoil in water to form long threads (Wong \& Hyde 1999a). In our phlogenetic tree (Fig. 1), C. receptaculorum clusters with $P$. thailandensis but they have over 70 nucleotide difference in LSU sequence data which also support them to be different genera. Considering the morphological similarity of annulatascaceae-like taxa and the lack of sequence data from the type species $C$. aquatica, we retain Cataractispora in Annulatascaceae as suggested by Hyde et al. (2020).

Zhang et al. (2017) introduced Pseudoproboscispora thailandensis in Pseudoproboscisporaceae, however, another species $P$. caudae-suis clusters in Annulatascaceae (Fig. 1). Pseudoproboscispora caudae-suis was transferred from Ceriospora based on its morphological similarity to $P$. aquatica (type) (Campbell et al. 2003). However, species in Pseudoproboscispora, such as $P$. aquatica and $P$. thailandensis, as well as their relatives Cataractispora, Diluviicola and Neodiluviicola, have filamentous appendages, which initially coiled or proboscis-like or cap-like then unfurl to form long threads. Whereas, P. caudae-suis has tail-like appendages that straight and persistent near base and coiled towards the apex (holotype IMI 38506) (Ingold 1951). In addition, the asci of $P$. caudae-suis have an apical pore, which is never seen in Pseudoproboscispora, even in Pseudoproboscisporaceae (Ingold 1951, Zhang et al. 2017, this study). Phylogenetically, two strains A40-1A and A336-2D which are both under the name $P$. caudae-suis (Campbell et al. 2003) cluster in Annulatascaceae rather than in Pseudoproboscisporaceae (Fig. 1). Also, at least one strain was probably misidentified as they have more than 100 nucleotide differences in LSU sequence data. Although $P$. caudae-suis morphologically does not belong in Pseudoproboscispora, we do not exclude it from Pseudoproboscispora until sequence data from epitype of $P$. caudae-suis and $P$. aquatica are obtained.

In this study, we provide a new collection of Diluviicola capensis, the type species of Diluviicola, with DNA sequence data which is phylogenetically distanct from $D$. aquatica. Thus, D. aquatica is transferred to a new genus Neodiluviicola based on morphology and phylogeny.

Diluviicola K.D. Hyde, S.W. Wong \& E.B.G. Jones, Fungal Diversity Res. Ser. 1: 141 (1998)

Type species - Diluviicola capensis K.D. Hyde, S.W. Wong \& E.B.G. Jones

Notes - Diluviicola was introduced for a freshwater species D. capensis collected from Brunei (Hyde et al. 1998). Diluviicola is unique in having bipolar conical caps attached to ascospore tips and detached once released in water, with a flexible filament which unfurls from within the caps (Hyde et al. 1998). Zhang et al. (2017) introduced a new species D. aquatica based on its similar ascomata lying horizontally on the host substrate and unfurling mechanisms of ascospore appendages with $D$. capensis. We provide sequence data for $D$. capensis with a description and illustration, and transfer $D$. aquatica to a new genus Neodiluviicola based on morphology and phylogeny (see notes under Neodiluviicola).

Diluviicola capensis K.D. Hyde, S.W. Wong \& E.B.G. Jones, Fungal Diversity 1: 134 (1998)

Facesoffungi number: FoF 09564

Fig. 28 
Saprobic on submerged wood in freshwater. Sexual morph: Ascomata scattered to gregarious, semi-immersed or superficial, ellipsoidal to obpyriform, black, lying horizontally on the host substrate, coriaceous, soft, ostiolate, with a lateral, short neck. Peridium very thin, easily cracked, comprising few layers of brown cells. Paraphyses $11.5 \mu \mathrm{m}$ diam. at the widest, tapering, uneven subcylindrical, septate, constricted at septa, unbranched, hyaline. Asci 190-210 $\times 13-15 \mu \mathrm{m}(\bar{x}=$ $200 \times 14 \mu \mathrm{m}, \mathrm{n}=5), 8$-spored, unitunicate, cylindrical, apex slightly truncate, tapering pedicellate, with a large, refractive, wedge-shaped, apical ring, 2.8-3 $\times 4.4-4.9 \mu \mathrm{m}$. Ascospores 25-30 $\times 8.3-10$ $\mu \mathrm{m}(\bar{x}=27 \times 9.2 \mu \mathrm{m}, \mathrm{n}=35)$, obliquely uniseriate, hyaline, fusiform, with truncate ends, straight or slightly curved, aseptate, 2-3-septate when germinated, minutely guttulate, thin-walled, smooth, with bipolar caps. Caps 6-7.5 × 3-3.8 $\mu \mathrm{m}(\bar{x}=6.7 \times 3.5 \mu \mathrm{m}, \mathrm{n}=10)$, conical, attached at each ascospore tip and detached once released in water, with a single sticky, thin, flexible filament unfurls from within the caps. The end of the filament is connected to the collar-like structure at the ascospore tip and eventually forming a long thread-like polar appendage. Asexual morph: Undetermined.
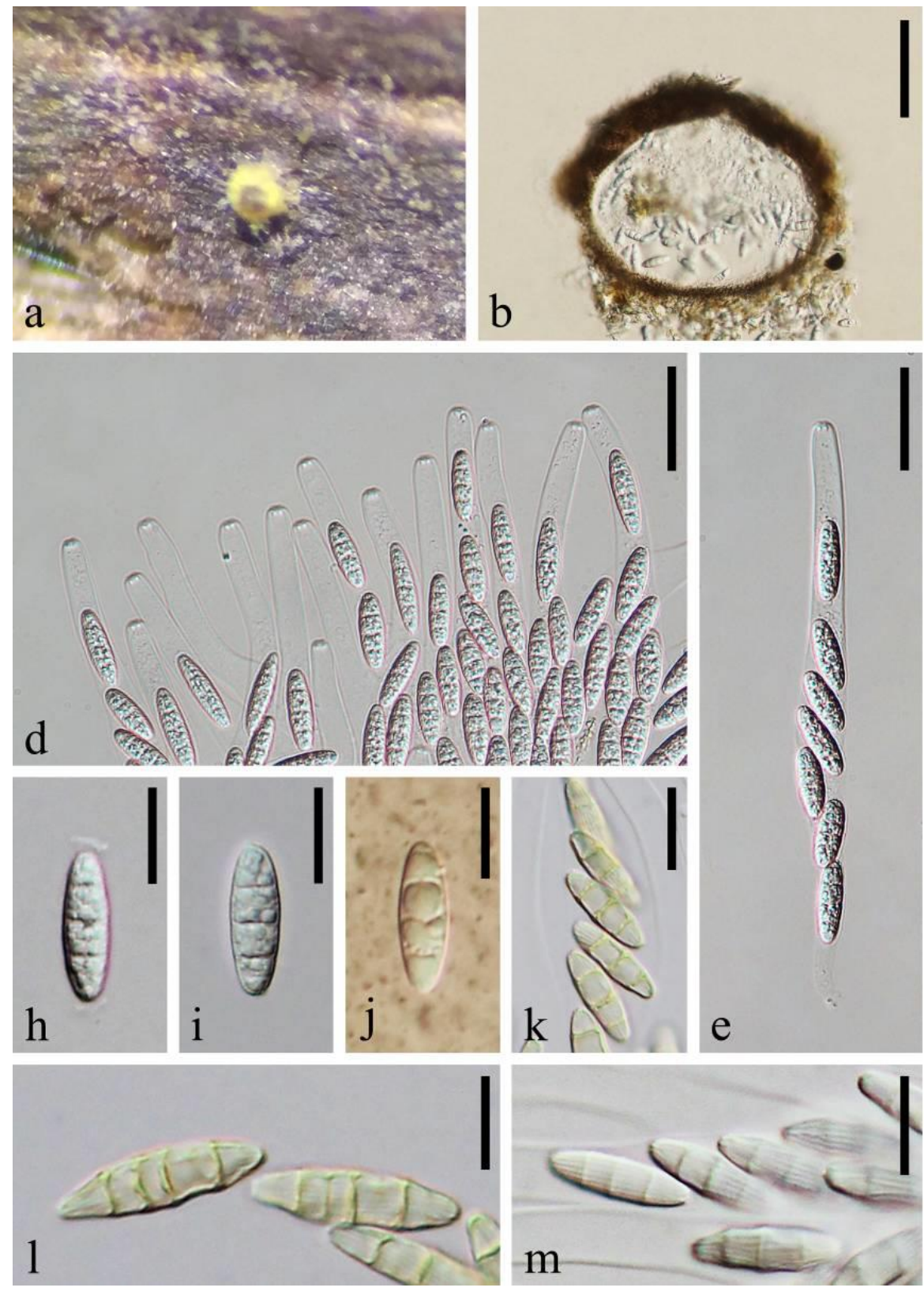
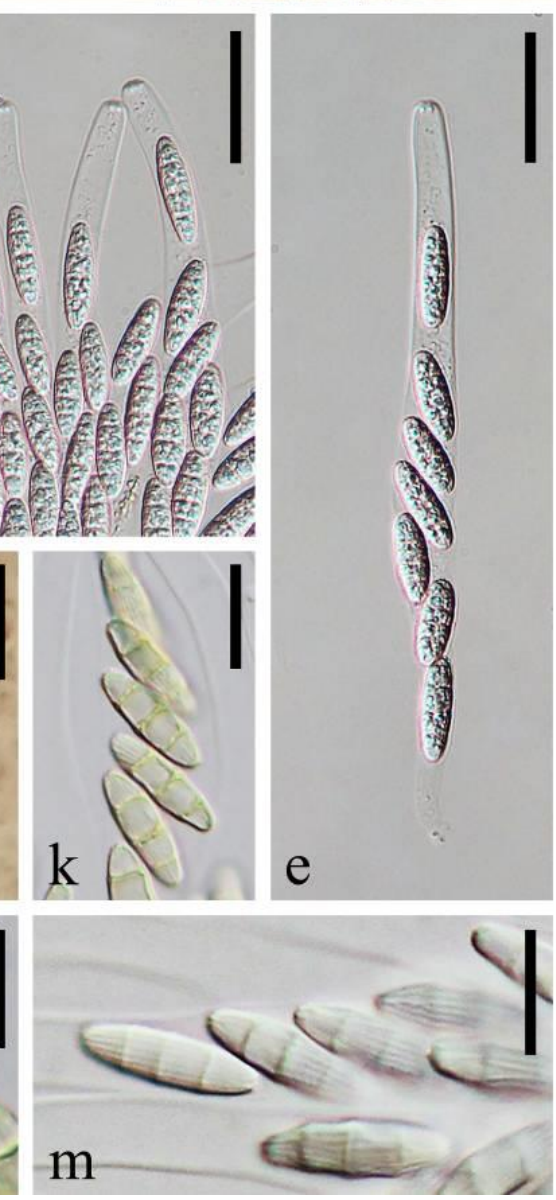
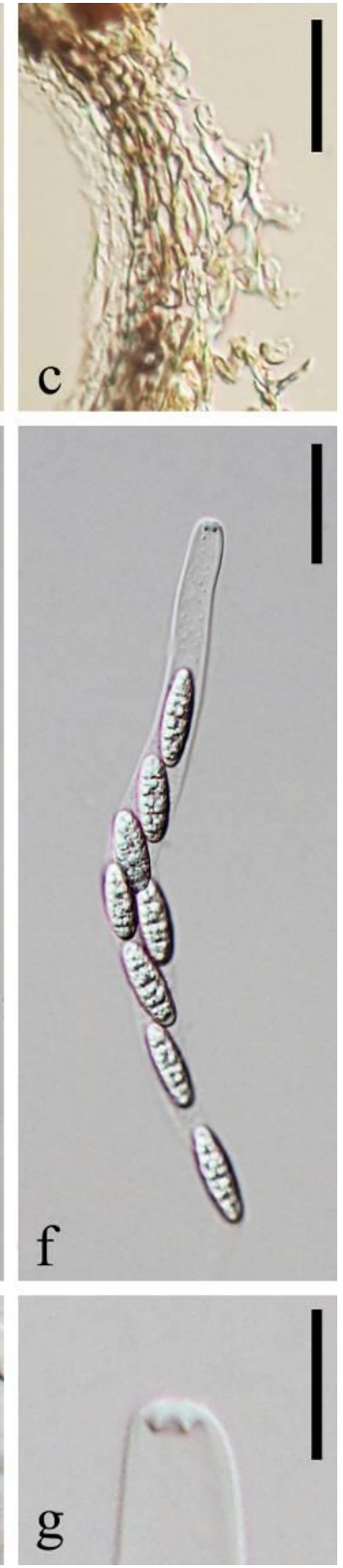

Figure 27 - Fluminicola striata (MFLU 18-1004, holotype). a Appearance of necks of ascomata on host. b Vertical section of ascoma. c Structure of peridium. d-f Unitunicate asci. g Apical ring. 
$\mathrm{h}-\mathrm{m}$ Ascospores ( $\mathrm{j}$ ascospore in Indian Ink; $\mathrm{k}, \mathrm{l}$ ascospores in Melzer's reagent). Scale bars: $\mathrm{b}=50$ $\mu \mathrm{m}, \mathrm{c}, \mathrm{k}=20 \mu \mathrm{m}, \mathrm{d}-\mathrm{f}=30 \mu \mathrm{m}, \mathrm{g}, \mathrm{l}=10 \mu \mathrm{m}, \mathrm{h}-\mathrm{j}, \mathrm{m}=15 \mu \mathrm{m}$.
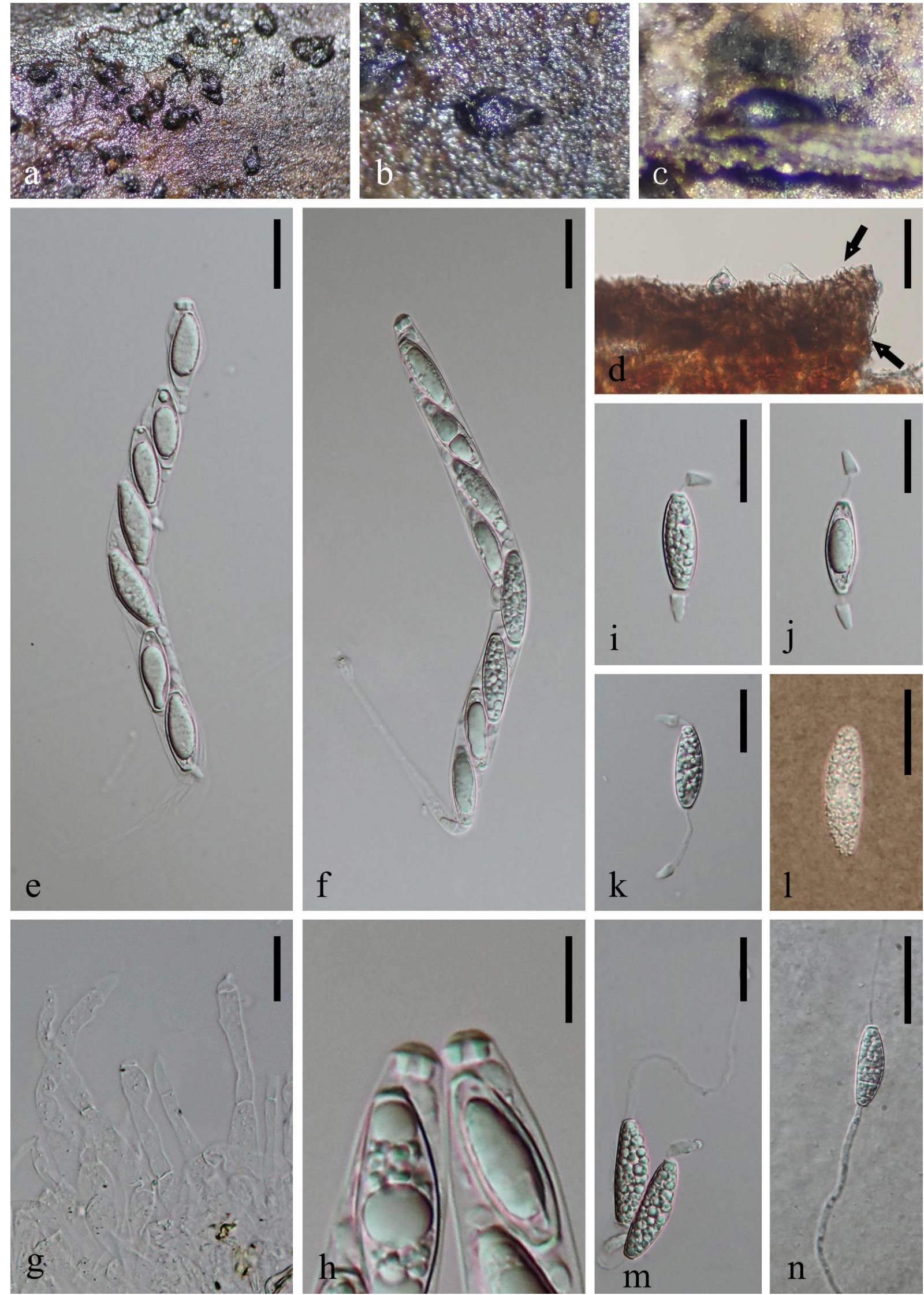

Figure 28 - Diluviicola capensis (MFLU 18-1717). a, b Ascomata on host substrate. c Section of ascoma. d Squashed peridium as arrowed. e, f Unitunicate asci. g Paraphyses. h Apical rings. 
$\mathrm{i}-\mathrm{m}$ Ascospores ( 1 ascospore in Indian Ink). $\mathrm{n}$ Germinated ascospore. Scale bars: $\mathrm{d}, \mathrm{n}=30 \mu \mathrm{m}$, $\mathrm{e}-\mathrm{g}, \mathrm{i}-\mathrm{m}=20 \mu \mathrm{m}, \mathrm{h}=10 \mu \mathrm{m}$.

Material examined - Thailand, Songkhla Province, on submerged wood in a stream, 10 May 2018, W. Dong, hat393 (MFLU 18-1717), living culture KUMCC 19-0088; ibid., HKAS 105071; ibid., hat108N, KUMCC 19-0089.

Notes - Diluviicola capensis was initially collected from a freshwater stream in Brunei (Hyde et al. 1998). Our Thai specimen KUMCC 19-0088 resembles the holotype of D. capensis in all aspects of morphological characteristics, except for shorter asci (190-210 × 13-15 $\mu \mathrm{m}$ vs. 266-326 $\times 11-14 \mu \mathrm{m}$ ). This is a new geographical record of D. capensis in Thailand. Diluviicola capensis forms a basal clade in Pseudoproboscisporaceae but with low bootstrap support. Morphologically, D. capensis fits well with familial concept of Pseudoproboscisporaceae by ascomata lying horizontally on the host substrate, with a lateral neck, and fusiform ascospores with bipolar caps which attached at each ascospore tip and detached once released in water.

Neodiluviicola W. Dong \& H. Zhang, gen. nov.

Index Fungorum number: IF558080; Facesoffungi number: FoF 09565

Etymology - in reference to the morphologically similar genus Diluviicola

Saprobic on submerged bamboo or wood. Sexual morph: Ascomata scattered or solitary, semi-immersed to superficial, subglobose or ellipsoidal, black, with a lateral, short neck. Necks black, lying horizontally on the host substrate or curving upwards. Peridium thin, comprising several layers of dark brown to black, compressed cells of textura angularis. Paraphyses numerous, cylindrical, unbranched, hyaline, septate, tapering towards the apex. Asci 8-spored, unitunicate, clavate to subcylindrical, pedicellate, with a distinct, refractive, wedge-shaped, apical ring. Ascospores obliquely uni-seriate or partially biseriate or sometimes triserial, fusiform, straight or slightly curved, aseptate or occasionally 1-septate, hyaline, thin-walled, with bipolar filamentous appendages. Appendages initially coiled in the bipolar chambers of ascospores then unfurl from within the chambers after releasing. Asexual morph: Undetermined.

Type species - Neodiluviicola aquatica (W. Dong et al.) W. Dong \& H. Zhang

Notes - Diluviicola aquatica was introduced based on its morphological similarities with the type species $D$. capensis in having black ascomata with a short, lateral neck and the same unfurling mechanism of ascospore appendages (Hyde et al. 1998, Zhang et al. 2017). However, D. aquatica is phylogenetically distant from $D$. capensis and forms a basal branch to Cataractispora and Pseudoproboscispora (Fig. 1). We notice that D. aquatica and D. capensis have different unfurling mechanisms of appendages. The appendages of $D$. aquatica initially coiled in the chambers of ascospores then unfurl from within the chambers after their release (Zhang et al. 2017). In contrast, the appendages of $D$. capensis are coiled in the conical cap which detached from the tip of ascospores once released in water and unfurl from within the cap (Hyde et al. 1998, this study). In addition, $D$. aquatica has clavate asci, while $D$. capensis has cylindrical asci.

Pseudoproboscispora has a similar appendage unfurling mechanism that is initially coiled and then unfurls in water to form long threads (Wong et al. 1999a), but lacks bipolar chambers containing coiled appendages. Instead, its appendages are initially proboscis-like, which also differ from $D$. aquatica. Therefore, we establish a new genus Neodiluviicola to accommodate $D$. aquatica. Different unfurling mechanisms of ascospore appendages of three genera and one species in Pseudoproboscisporaceae are summarized in Table 3.

Neodiluviicola aquatica (W. Dong, H. Zhang \& K.D. Hyde) W. Dong \& H. Zhang, comb. nov.

Index Fungorum number: IF558081; Facesoffungi number: FoF 09566

Basionym - Diluviicola aquatica W. Dong, H. Zhang \& K.D. Hyde, Fungal Diversity 85: 93 (2017)

Holotype - MFLU 15-2701 
Known distribution - (based on molecular data) - Thailand

Known habitat - (based on molecular data) - freshwater

For description of this fungus see Zhang et al. (2017)
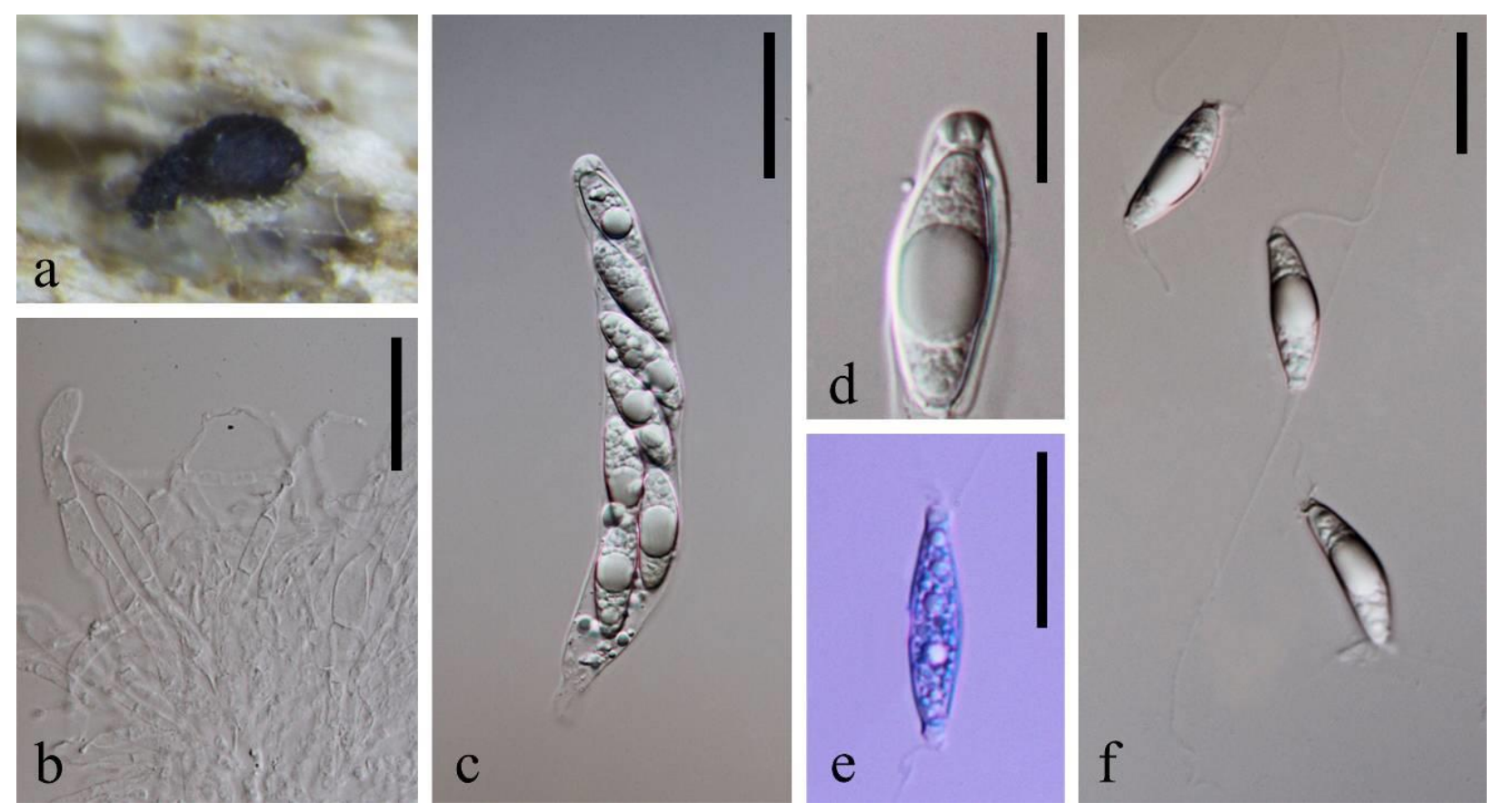

Figure 29 - Neodiluviicola aquatica (MFLU 15-2701). a Ascoma on host substrate. b Paraphyses. c Unitunicate ascus. d Apical ring. e, f Ascospores (e ascospore in cotton blue reagent). Scale bars: $\mathrm{b}, \mathrm{c}=30 \mu \mathrm{m}, \mathrm{d}=15 \mu \mathrm{m}, \mathrm{e}, \mathrm{f}=20 \mu \mathrm{m}$.

\section{Diaporthomycetidae genera incertae sedis}

Aquidictyomyces W. Dong, H. Zhang \& K.D. Hyde, gen. nov.

Index Fungorum number: IF558082; Facesoffungi number: FoF 09567 conidia

Etymology - in reference to aquatic habitat where the fungus was collected and dictyoseptate

Saprobic on submerged wood in freshwater. Sexual morph: Undetermined. Asexual morph: Hyphomycetous. Colonies superficial, effuse, gregarious, hairy, pale brown. Mycelium mostly immersed, composed of septate, branched, pale brown, thin-walled hyphae. Conidiophores macronematous, mononematous, erect, cylindrical, straight or slightly flexuous, septate, robust at the base, unbranched, brown, paler at the apex, smooth. Conidiogenous cells holoblastic, monoblastic, integrated, determinate, terminal, subcylindrical, pale brown, smooth. Conidia acrogenous, solitary, dry, thin-walled, smooth-walled, ginger-shaped, pale brown, dictyoseptate, constricted at septa, with one primary central, longitudinal septa, with transverse or oblique septa, with some protuberances at the apex, rounded or truncate at the base, with two tapering arms curving upwards at two sides, attached fibroid, hyaline appendages.

Type species - Aquidictyomyces appendiculatus W. Dong, H. Zhang \& K.D. Hyde

Notes - Based on a blastn search of NCBIs GenBank, the closest hits using LSU sequence of Aquidictyomyces appendiculatus are some annulatascaceae-like genera in Diaporthomycetidae, viz. Barbatosphaeria (92.97\%), Bullimyces (93.32\%), Ceratolenta $(93.10 \%)$ and Conlarium (92.99\%). However, they can be easily distinguished by conidial shape. Our phylogenetic analysis shows that A. appendiculatus forms a distinct lineage in Diaporthomycetidae and has a weak relationship with Trichosphaeriaceae (Fig. 1). Morphologically, A. appendiculatus does not fit with the familial concept of Trichosphaeriaceae and any of other families in Diaporthomycetidae (Hyde et al. 2020). 
We therefore place A. appendiculatus in a new genus Aquidictyomyces, and refer it to Diaporthomycetidae genera incertae sedis.

Table 3 Different unfurling mechanisms of ascospore appendages of Cataractispora receptaculorum, Diluviicola, Neodiluviicola and Pseudoproboscispora

\begin{tabular}{|c|c|c|}
\hline Taxa & Unfurling mechanisms & References \\
\hline $\begin{array}{l}\text { Cataractispora } \\
\text { receptaculorum }\end{array}$ & Initially in the form of mucilaginous pads and then unfurl readily in water to form long threads & Ho et al. 2004 \\
\hline Diluviicola & $\begin{array}{l}\text { Initially coiled in the conical cap which detached from the tip of ascospores once released in water and } \\
\text { unfurl from within the cap }\end{array}$ & Hyde et al. 1998, this study \\
\hline Neodiluviicola & Initially coiled in the chambers of ascospores then unfurl from within the chambers after releasing & Zhang et al. 2017 \\
\hline Pseudoproboscispora & Initially coiled as proboscis-like and then unfurl in water to form long threads & Wong et al. 1999a, Zhang et al. 2017 \\
\hline
\end{tabular}

Aquidictyomyces appendiculatus W. Dong, H. Zhang \& K.D. Hyde, sp. nov.

Fig. 30

Index Fungorum number: IF558083; Facesoffungi number: FoF 09568

Etymology - in reference to the long appendages of the fungus

Holotype - MFLU 18-1528

Saprobic on submerged wood in freshwater. Sexual morph: Undetermined. Asexual morph: Hyphomycetous. Colonies superficial, effuse, gregarious, hairy, pale brown. Mycelium mostly immersed, composed of septate, branched, pale brown, thin-walled hyphae. Conidiophores $35-140 \times$ 3-4.5 $\mu \mathrm{m}(\bar{x}=85 \times 4 \mu \mathrm{m}, \mathrm{n}=10)$, macronematous, mononematous, erect, cylindrical, straight or slightly flexuous, septate, robust at the base, unbranched, brown, paler at the apex, smooth. Conidiogenous cells 5-50 $\times 2.5-3.5 \mu \mathrm{m}(\bar{x}=22 \times 3 \mu \mathrm{m}, \mathrm{n}=10)$, holoblastic, monoblastic, integrated, determinate, terminal, subcylindrical, pale brown, smooth. Conidia 11-14.5 $\times 7-9.5 \mu \mathrm{m}(\bar{x}=13 \times 8.5 \mu \mathrm{m}, \mathrm{n}=20)$, acrogenous, solitary, dry, thinwalled, smooth-walled, ginger-shaped, hyaline to pale brown, dictyoseptate, with one primary central, longitudinal, straight or curved septum, mostly with two transverse or oblique septa, constricted at septa, with 4-8 protuberances at the apex, rounded or truncate at the base, with two tapering, persistent arms curving upwards at two sides of the body, attached fibroid, hyaline appendages, 4-9 $\mu \mathrm{m}$ long for arms and 17-45 $\mu \mathrm{m}$ long for appendages.

Culture characteristics - On PDA, colony circular, slow growing, reaching $7 \mathrm{~mm}$ in 30 days at $25^{\circ} \mathrm{C}$, white and pale brown from above, black from below, surface rough, dry, with dense mycelium, raised, entire at edge.

Material examined - Thailand, Songkhla Province, on submerged wood in a stream, 10 May 2018, W. Dong, 20180517 (MFLU 18-1528, holotype), ex-type living culture KUMCC 19-0061; ibid., HKAS 105043, isotype. 

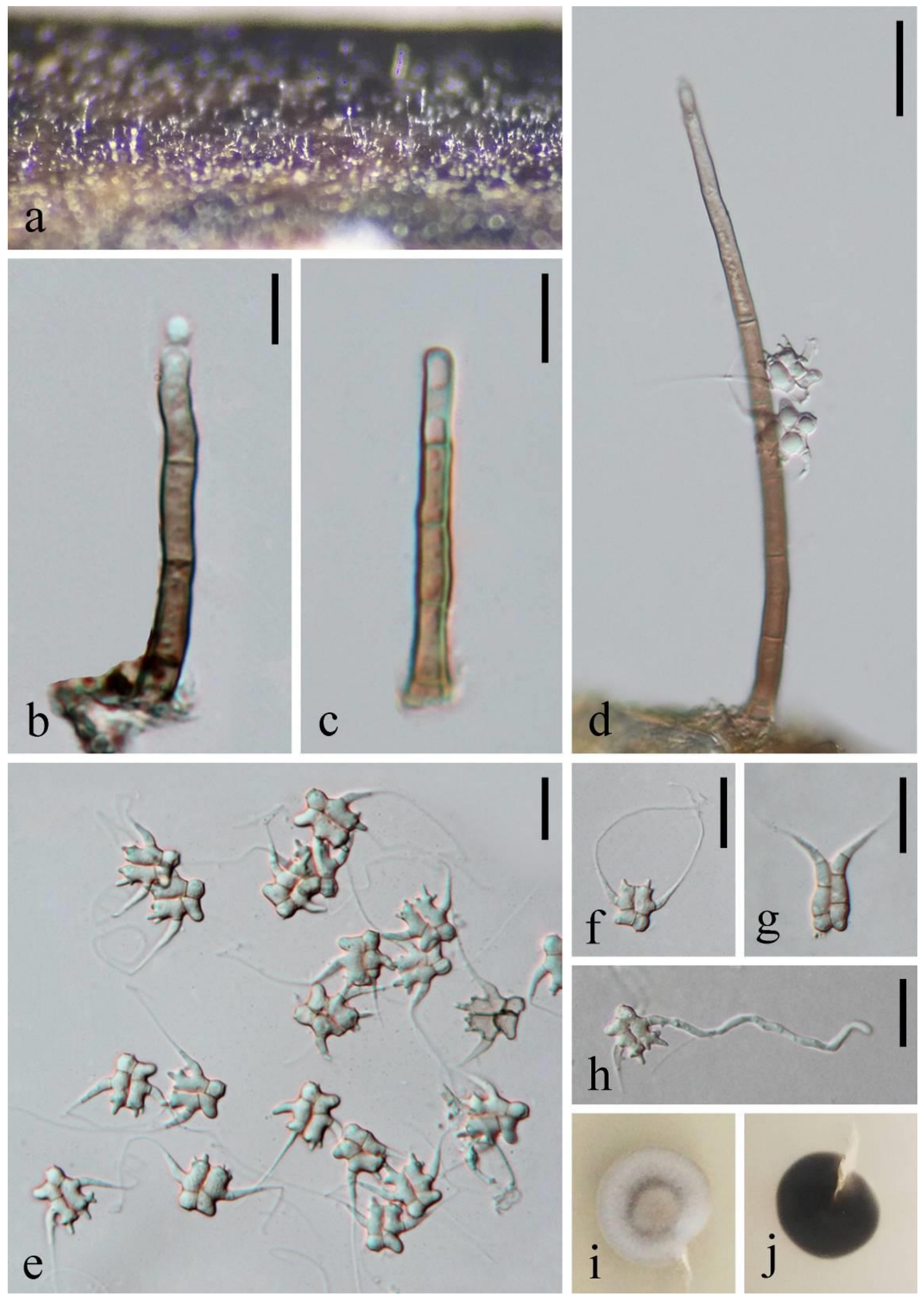

Figure 30 - Aquidictyomyces appendiculatus (MFLU 18-1528, holotype), a Colonies on submerged wood. b-d Conidiophores with conidia. e-g Conidia. h Germinated conidium. $\mathrm{i}, \mathrm{j}$ Colony on PDA (left-front, right-reverse). Scale bars: $\mathrm{b}, \mathrm{c}=10 \mu \mathrm{m}, \mathrm{d}-\mathrm{h}=15 \mu \mathrm{m}$. 


\section{Discussion}

Since Maharachchikumbura et al. (2015) established Annulatascales to accommodate Annulatascaceae with 18 genera, taxonomic studies on Annulatascales attracted the attention of researchers as these genera were scattered in several unrelated clades in Diaporthomycetidae (Luo et al. 2015, Zhang et al. 2017, Hyde et al. 2020). In addition, the placements of several genera are unclear due to lack of DNA sequence data, e.g. Aqualignicola, Ayria, Chaetorostrum, Clohiesia and Vertexicola (Hyde et al. 2020). The monophyly of Annulatascales is not well-supported in our phylogenetic analysis, except Annulusmagnus and Ascitendus which cluster together with good bootstrap support (Fig. 1). Annulusmagnus, Ascitendus, Longicollum and Submersisphaeria group together in a distinct clade in all recent studies (Luo et al. 2019, Hyde et al. 2020) and this study, but without bootstrap support. In our evolutionary tree (data not shown), these four genera also constitute a separate clade to Annulatascus. The divergence time of this clade is estimated as 137 MYA that falls in the range for family status (50-150 MYA) suggested by Hyde et al. (2017). However, we do not place these four genera in a new family now due to their weak relationships (Fig. 1). We consider that the higher ranking of taxa should be proposed only when sufficient morphological data are obtained and the phylogenetic relationships of these genera are clear enough, but the relatively long necks of Annulusmagnus, Longicollum and Submersisphaeria (Wong et al. 1999c, Campbell et al. 2003, Zelski et al. 2011) will be one of the characters to separate families in Annulatascales. Although Paoayensis clusters in Annulatascales (Luo et al. 2019, Hyde et al. 2020; this study, Fig. 1), its 2-6-spored asci and absence of large apical ring do not support Paoayensis in Annulatascales (Cabanela et al. 2007). Paoayensis is currently referred to Sordariomycetes genera incertae sedis (Luo et al. 2019, Hyde et al. 2020, Wijayawardene et al. 2020). The placements of two new genera Fusoidigranularius and Longivarius are also unstable in Annulatascaceae as shown in different papers (Zhang et al. 2017, Luo et al. 2019, Hyde et al. 2020, this study). We place them in Annulatascaceae based on current phylogenetic analysis.

The morphological characteristics of all sequenced genera in Annulatascaceae are summarized in Table 4. These genera are similar to the type genus Annulatascus in having ascomata with necks, but Ascitendus has a minute papilla and other genera have relatively longer necks than Annulatascus, especially the neck of Longicollum is up to $370 \mu \mathrm{m}$ long (Zelski et al. 2011). Of these genera, only Fusoidigranularius has a long pedicel which is similar to Annulatascus, but the ascospores of Fusoidigranularius are entirely different from Annulatascus. All genera have similar ascospore shape and colour, except that Ascitendus and Longivarius have unevenly coloured ascospores and Submersisphaeria has brown ascospores. Although these genera share few morphological characteristics, all of them have cylindrical asci with a large apical ring. The phylogenetic relationships of these genera are unclear and more data are needed to clarify their taxonomy. A narrower definition of Annulatascaceae cannot be provided in this study, until Annulatascaceae members form a monophyletic clade with a good bootstrap support.

The genera that morphologically resemble Annulatascus but are phylogenetically distant from Annulatascaceae and those that lack sequence data, are treated as annulatascaceae-like taxa, e.g. Diluviicola, Fluminicola and Pseudoproboscispora. A natural classification of annulatascaceae-like taxa was carried out by Zhang et al. (2017) with introducing a new order and six new families. However, several taxa are uncertain and referred to Diaporthomycetidae genera incertae sedis (Aquaticola) or temporarily in Annulatascaceae (viz. Aqualignicola, Ayria, Cataractispora, Chaetorostrum and Vertexicola) (Hyde et al. 2020).

In previous taxonomic studies, most researchers focused on morphological characteristics of ascomata, asci and ascospores of annulatascaceae-like species, and neglected their asexual morphs. Asexual morphs of Annulatascaceae are poorly studied and Zelski et al. (2011) reported one taeniolella-like asexual morph from culture of Chaetorostrum quincemilensis which was placed in Annulatascaceae, but without support from molecular data. Zhang et al. (2017) and Luo et al. (2019) linked annulatascaceae-like taxa to several asexual genera, i.e. Dictyosporella and Sporidesmium, based on sequence data. This provided more evidence to separate annulatascaceae- 
Table 4 Morphological characteristics of Annulatascus, Annulusmagnus, Ascitendus, Fusoidigranularius, Longicollum, Longivarius and Submersisphaeria

\begin{tabular}{|c|c|c|c|c|c|c|c|c|}
\hline \multirow[b]{2}{*}{ Genera } & \multirow[b]{2}{*}{ Ascomata } & \multicolumn{2}{|l|}{ Asci } & \multicolumn{4}{|l|}{ Ascospores } & \multirow[b]{2}{*}{ References } \\
\hline & & Shape & Apical ring & Shape & Colour & Septation & $\begin{array}{l}\text { Appendage or } \\
\text { sheath }\end{array}$ & \\
\hline Annulatascus & $\begin{array}{l}\text { With a short } \\
\text { neck }\end{array}$ & $\begin{array}{l}\text { Cylindrical, } \\
\text { mostly long } \\
\text { pedicellate }\end{array}$ & $3-8 \times 2-7 \mu \mathrm{m}$ & Fusiform & Hyaline & $\begin{array}{l}\text { Mostly } \\
\text { aseptate }\end{array}$ & $\begin{array}{l}\text { With } \\
\text { inconspicuous } \\
\text { appendages and } \\
\text { often with a thin or } \\
\text { large sheath }\end{array}$ & $\begin{array}{l}\text { Hyde 1992, Ho et al. 1999a, } \\
\text { Luo et al. 2015, Dayarathne } \\
\text { et al. 2016, Hyde et al. } \\
\text { 2020, this study }\end{array}$ \\
\hline Annulusmagnus & $\begin{array}{l}\text { With a long } \\
\text { neck, hyaline at } \\
\text { the apex }\end{array}$ & $\begin{array}{l}\text { Cylindrical, } \\
\text { short } \\
\text { pedicellate }\end{array}$ & $3 \times 5.5 \mu \mathrm{m}$ & Fusiform & Hyaline & 3 -septate & $\begin{array}{l}\text { With a thin } \\
\text { mucilaginous } \\
\text { sheath, which } \\
\text { comprises } \\
\text { episporial fibrillar } \\
\text { material }\end{array}$ & Wong et al. 1999c \\
\hline Ascitendus & $\begin{array}{l}\text { With a minute } \\
\text { papilla }\end{array}$ & $\begin{array}{l}\text { Cylindrical, } \\
\text { short or long } \\
\text { pedicellate }\end{array}$ & $\begin{array}{l}2.5-3.5 \times 3- \\
3.8 \mu \mathrm{m}\end{array}$ & $\begin{array}{l}\text { Ellipsoidal to } \\
\text { fusiform }\end{array}$ & $\begin{array}{l}\text { Central cells } \\
\text { pale brown, } \\
\text { end cells } \\
\text { subhyaline to } \\
\text { pale brown }\end{array}$ & 3-septate & No & Campbell \& Shearer 2004 \\
\hline Fusoidigranularius & $\begin{array}{l}\text { With an upward } \\
\text { bend, relatively } \\
\text { long neck } \\
\text { growing laterally }\end{array}$ & $\begin{array}{l}\text { Cylindrical, } \\
\text { long } \\
\text { pedicellate }\end{array}$ & $3-4 \times 5-6 \mu \mathrm{m}$ & Long fusoid & Hyaline & $\begin{array}{l}5-9(-11)- \\
\text { septate }\end{array}$ & $\begin{array}{l}\text { With a large, } \\
\text { gelatinous, } \\
\text { irregular, granular } \\
\text { sheath }\end{array}$ & Abdel-Wahab et al. 2011 \\
\hline Longicollum & With a long neck & $\begin{array}{l}\text { Cylindrical, } \\
\text { short } \\
\text { pedicellate }\end{array}$ & $2-4 \times 3-5 \mu \mathrm{m}$ & $\begin{array}{l}\text { Broadly } \\
\text { ellipsoidal }\end{array}$ & Hyaline & Aseptate & $\begin{array}{l}\text { With short hyaline, } \\
\text { bipolar, ephemeral, } \\
\text { mucilaginous } \\
\text { appendages }\end{array}$ & Zelski et al. 2011 \\
\hline Longivarius & $\begin{array}{l}\text { With a relatively } \\
\text { long neck, } \\
\text { curving or } \\
\text { becoming erect }\end{array}$ & $\begin{array}{l}\text { Cylindrical, } \\
\text { short } \\
\text { pedicellate }\end{array}$ & $\begin{array}{l}5.0-7.5 \mu \mathrm{m} \\
\text { wide }\end{array}$ & $\begin{array}{l}\text { Fusoid to } \\
\text { lunate }\end{array}$ & $\begin{array}{l}\text { Central cells } \\
\text { brown, end } \\
\text { cells } \\
\text { subhyaline }\end{array}$ & 3-septate & No & Boonyuen et al. 2012 \\
\hline Submersisphaeria & With a long neck & $\begin{array}{l}\text { Cylindrical, } \\
\text { short } \\
\text { pedicellate }\end{array}$ & $4-6 \times 5-6 \mu \mathrm{m}$ & $\begin{array}{l}\text { Ellipsoidal to } \\
\text { oval }\end{array}$ & Brown & 1-septate & $\begin{array}{l}\text { With very small, } \\
\text { hyaline, cap-like } \\
\text { appendages }\end{array}$ & Campbell et al. 2003 \\
\hline
\end{tabular}



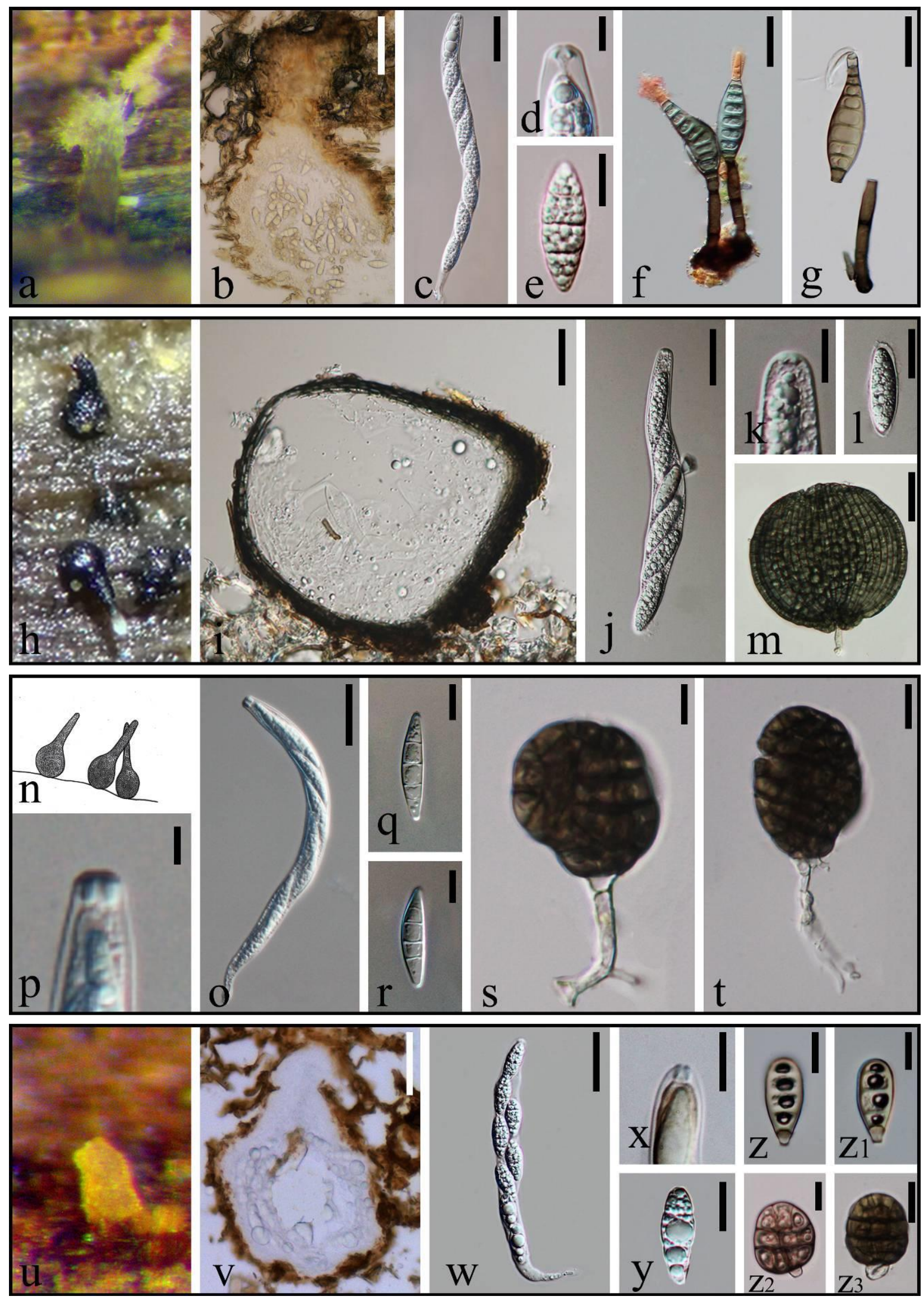

Figure 31 - Annulatascaceae-like morphs and some asexual morphs. a-g Sporidesmiales spp. a-e Sporidesmium thailandense (MFLU 15-2709, holotype). f, g S. appendiculatum (MFLU 180981, holotype). h-m Cancellidiales spp. h-1 Obliquiminima hyalina (MFLU 18-1521, holotype). 
m Cancellidium thailandense (MFLU 18-1510, holotype). n-t Conlariales spp. n- $\mathrm{r}$ Conlarium duplumascospora (HMAS243129, holotype). s, $\mathrm{t} C$. aquaticum (MFLU 18-1181). $\mathrm{u}-\mathrm{Z}_{3}$ Junewangiaceae spp. u Dictyosporella thailandensis (MFLU 15-2706, holotype). v-y D. chiangmaiensis (MFLU 17-1707, holotype). z, z $\mathrm{z}_{1}$ Sporidesmiella obovoidia (MFLU 171731, holotype). $\mathrm{z}_{2}$ Junewangia thailandica (MFLU 15-2682, holotype). $\mathrm{z}_{3}$ Dictyosporella ellipsoidea (MFLU 18-1209, holotype). a, h, n, u Ascomata. b, i, v Vertical sections of ascomata. c, j, o, w Unitunicate asci. d, k, p, x Apical rings. e, l, q, r, y Ascospores. f, g Conidiophores with conidia. $\mathrm{m}, \mathrm{s}, \mathrm{t}, \mathrm{z}-\mathrm{z}_{3}$ Conidia. Scale bars: $\mathrm{b}, \mathrm{v}=50 \mu \mathrm{m}, \mathrm{c}, \mathrm{f}, \mathrm{i}, \mathrm{j}, \mathrm{m}, \mathrm{o}, \mathrm{w}=30 \mu \mathrm{m}, \mathrm{d}, \mathrm{p}=5 \mu \mathrm{m}$, $\mathrm{e}, \mathrm{k}, \mathrm{q}-\mathrm{t}, \mathrm{x}-\mathrm{z}_{2}=10 \mu \mathrm{m}, \mathrm{g}, 1, \mathrm{z}_{3}=20 \mu \mathrm{m}$.

like taxa with morphological characteristics of their asexual morphs. However, there are few reports on annulatascaceae-like taxa reproducing conidia in culture, as well as from our new collections. It is likely that sexual morphs of annulatascaceae-like taxa are not common in southwest of China and Thailand as observed during our continuous study on freshwater fungi since 2010 (Zhang et al. 2011, 2013, 2016, Dong et al. 2018, 2020a, b, 2021, Yu et al. 2018, Wang et al. 2019). The NCBI blast results show that our 30 collections have affinities to Annulatascaceae or annulatascaceae-like taxa, however, 19 of them are asexual morphs.

Several asexual orders or families which are phylogenetically closely related to annulatascaceae-like taxa are included in this study, viz. Acrodictyaceae, Cancellidiales, Conlariales, Distoseptisporales, Junewangiaceae and Sporidesmiales. Of these, annulatascaceaelike morphs have been found in Sporidesmiales (Sporidesmium lignicola and S. thailandense), Cancellidiales (Obliquiminima hyalina gen. et sp. nov.), Conlariales (Conlarium duplumascospora) and Junewangiaceae (Dictyosporella chiangmaiensis sp. nov. and D. thailandensis). The morphological characteristics of these annulatascaceae-like morphs and asexual morphs which belong in the same family or order are illustrated in a combined photo plate (Fig. 31). These annulatascaceae-like morphs are similar in having cylindrical asci with a distinctive, refractive, mostly wedge-shaped, apical ring, however, the ascomata can distinguish them (Fig. 31a, h, n, u). It clearly shows that their related asexual morphs can be easily distinguished with distinct morphology (Fig. 31f, g, m, s, t, z-z $\mathbf{z}_{3}$ ). It is, therefore, necessary to study annulatascaceae-like taxa together with their related asexual morphs.

It is worth mentioning that Sporidesmium (Sporidesmiaceae) is a complex and large genus as species are morphologically very similar and few characteristics can be compared. Although two annulatascaceae-like morphs have been reported in Sporidesmium sensu stricto based on molecular data (Zhang et al. 2017, Luo et al. 2019), there is not enough evidence to classify those Sporidesmium sensu lato. We believe that with more annulatascaceae-like taxa found in Sporidesmium, the natural classification of both sporidesmium-like and annulatascaceae-like taxa will become clearer. On the other hand, the family Distoseptisporaceae which was segregated from Sporidesmium was thought to differ from Sporidesmium by the colour of conidia and the length of conidiophores (Su et al. 2016). However, these characteristics are considered not significant enough to separate these two groups and molecular evidence is the main tool for their classification. The sexual morphs of Distoseptisporaceae are therefore necessary for further comparison with Sporidesmiaceae. Whether any unsequenced annulatascaceae-like taxa, e.g. Aqualignicola, Ayria, Chaetorostrum, Clohiesia and Vertexicola, will cluster in Distoseptisporaceae need further investigation.

\section{Acknowledgements}

This work was mainly supported by National Natural Science Foundation of China (Project ID: NSFC 31500017 to Huang Zhang), State Scholarship fund (201908530031), Yunnan young and middle aged academic and technical leaders reserve talents (Project ID: 2018HB008 to Di Zhang). Kevin D. Hyde thanks the Foreign Experts Bureau of Yunnan Province, Foreign Talents Program (2018; grant no. YNZ2018002), Thailand Research grants entitled Biodiversity, phylogeny and role of fungal endophytes on above parts of Rhizophora apiculata and Nypafruticans (grant no: 
RSA5980068), the future of specialist fungi in a changing climate: baseline data for generalist and specialist fungi associated with ants, Rhododendron species and Dracaena species (grant no: DBG6080013), Impact of climate change on fungal diversity and biogeography in the Greater Mekong Subregion (grant no: RDG6130001). Kevin D. Hyde also thanks Chiang Mai University for the award of Visiting Professor. Mingkwan Doilom would like to thank the 5th batch of Postdoctoral Orientation Training Personnel in Yunnan Province (grant no: Y934283261), the 64th batch of China Postdoctoral Science Foundation (grant no: Y913082271) and Chiang Mai University for Postdoctoral research funding. Dr. Fang Liu is sincerely thanked for providing materials of Conlarium duplumascospora in morphological study. We thank Prof. D. Jayarama Bhat for kindly perusing this manuscript.

\section{References}

Abdel-Wahab MA, Abdel-Aziz FA, Mohamed SS, Abdel-Aziz AE. 2011 - Annulatascus nilensis sp. nov., a new freshwater ascomycete from the River Nile, Egypt. IMA Fungus 2, 1-6.

Ariyawansa HA, Hyde KD, Jayasiri SC, Buyck B et al. 2015 - Fungal diversity notes 111-252 taxonomic and phylogenetic contributions to fungal taxa. Fungal Diversity 75, 27-274.

Baker WA, Partridge EC, Morgan-Jones G. 2002 - Notes on Hyphomycetes. LXXXV. Junewangia, a genus in which to classify four Acrodictys species and a new taxon. Mycotaxon 81, 293-320.

Barbosa FR, Gusmão LFP, Raja HA, Shearer CA. 2008 - Annulatascus apiculatus sp. nov., a new freshwater ascomycete from the semi-arid Caatinga biome of Brazil. Mycotaxon 106, 403 407.

Boonyuen N, Sri-Indrasutdhi V, Suetrong S, Sivichai S, Jones EBG. 2012 - Annulatascus aquatorba sp. nov., a lignicolous freshwater ascomycete from Sirindhorn Peat Swamp Forest, Narathiwat, Thailand. Mycologia 104, 746-757.

Cabanela MV, Jeewon R, Hyde KD. 2007 - Morphotaxonomy and phylogeny of Paoayensis lignicola gen. et sp. nov. (ascomycetes) from submerged wood in Paoay Lake, Ilocos Norte, the Philippines. Cryptogamie, Mycologie 28, 301-310.

Cai L, Hyde KD, Tsui CKM. 2006 - Genera of freshwater fungi. Fungal Diversity Press, Hong Kong

Cai L, Zhang KQ, McKenzie EHC, Hyde KD. 2003 - Freshwater fungi from bamboo and wood submerged in the Liput River in the Philippines. Fungal Diversity 13, 1-12.

Campbell J, Shearer CA. 2004 - Annulusmagnus and Ascitendus, two new genera in the Annulatascaceae. Mycologia 96, 822-833.

Campbell J, Shearer CA, Crane JL, Fallah PM. 2003 - A reassessment of two freshwater ascomycetes, Ceriospora caudae-suis and Submersisphaeria aquatica. Mycologia 95, 41-53.

Chomnunti P, Hongsanan S, Aguirre-Hudson B, Tian Q et al. 2014 - The sooty moulds. Fungal Diversity 66, 1-36.

Crous PW, Wingfield MJ, Burgess TI, Hardy GESJ et al. 2018 - Fungal Planet description sheets: 716-784. Persoonia: Molecular Phylogeny and Evolution of Fungi 40, 240-393.

Dai DQ, Phookamsak R, Wijayawardene NN, Li WJ et al. 2017 - Bambusicolous fungi. Fungal Diversity $82,1-105$.

Dayarathne M, Maharachchikumbura S, Phookamsak R, Fryar S et al. 2016 - Morpho-molecular characterization and epitypification of Annulatascus velatisporus. Mycosphere 7, 1389-1398.

Dayarathne MC, Maharachchikumbura SSN, Jones EBG, Dong W et al. 2019 - Phylogenetic revision of Savoryellaceae and evidence for its ranking as a subclass. Frontiers in Microbiology 10, 840.

Dong W, Hyde KD, Bhat DJ, Zhang H. 2018 - Introducing Aculeata aquatica gen. et sp. nov., Minimelanolocus thailandensis sp. nov. and Thysanorea aquatica sp. nov. (Herpotrichiellaceae, Chaetothyriales) from freshwater in northern Thailand. Mycological Progress 17, 617-629. 
Dong W, Hyde KD, Doilom M, Yu XD et al. 2020a - Pseudobactrodesmium (Dactylosporaceae, Eurotiomycetes, Fungi) a novel lignicolous genus. Frontiers in Microbiology 11, 456.

Dong W, Wang B, Hyde KD, McKenzie EHC et al. 2020b - Freshwater Dothideomycetes. Fungal Diversity $105,319-575$.

Dong W, Zhang H, Doilom M, Yu XD et al. 2021 - Rhexodenticula aquatica (Sordariomycetidae genera incertae sedis), a novel hyphomycete from freshwater in Thailand. Phytotaxa 483, 129-138.

Ellis MB. 1961 - Dematiaceous hyphomycetes. II. Mycological papers 79, 1-23.

Ellis MB 1971 - Dematiaceous hyphomycetes. Commonwealth Mycological Institute, Kew, Surrey, England

Ferrer A, Miller AN, Sarmiento C, Shearer CA 2012 - Three new genera representing novel lineages of Sordariomycetidae (Sordariomycetes, Ascomycota) from tropical freshwater habitats in Costa Rica. Mycologia 104, 865-879.

Fryar SC, Hyde KD. 2004 - New species and genera of ascomycetes from fresh and brackish water in Brunei: Ayria appendiculata and Sungaiicola bactrodesmiella gen. et spp. nov., Fluviatispora boothii, Torrentispora crassiparietis and T. fusiformis spp. nov. Cryptogamie, Mycologie 25, 245-260.

Hernandez-Gutierrez A, Sutton BC. 1997 - Imimyces and Linkosia, two new genera segregated from Sporidesmium sensu lato, and redescription of Polydesmus. Mycological Research 101, 201-209.

Ho WH, Hyde KD, Hodgkiss IJ. 2004 - Cataractispora receptaculorum, a new freshwater ascomycete from Hong Kong. Mycologia 96, 411-417.

Ho WH, Ranghoo VM, Hyde KD, Hodgkiss IJ. 1999a - Ascal ultrastructural study in Annulatascus hongkongensis sp. nov., a freshwater ascomycete. Mycologia 91, 885-892.

Ho WH, Tsui CKM, Hodgkiss IJ, Hyde KD. 1999b - Aquaticola, a new genus of Annulatascaceae from freshwater habitats. Fungal Diversity 3, 87-97.

Ho WH, Yanna, Hyde KD, Hodgkiss IJ. 2002 - Seasonality and sequential occurrence of fungi on wood submerged in Tai Po Kau Forest Stream, Hong Kong. Fungal Diversity 10, 21-43.

Hongsanan S, Maharachchikumbura SSN, Hyde KD, Samarakoon MC et al. 2017 - An updated phylogeny of Sordariomycetes based on phylogenetic and molecular clock evidence. Fungal Diversity 84, 25-41.

Hu DM, Cai L, Chen H, Bahkali AH, Hyde KD. 2010 - Fungal diversity on submerged wood in a tropical stream and an artificial lake. Biodiversity and Conservation 19, 3799-3808.

Hyde KD. 1992 - Tropical Australian freshwater fungi. II. Annulatascus velatispora gen. et sp. nov., A. bipolaris sp. nov. and Nais aquatica sp. nov. (Ascomycetes). Australian Systematic Botany 5, 117-124.

Hyde KD, Bao DF, Hongsanan S, Chethana KWT et al. 2021 - Evolution of freshwater Diaporthomycetidae (Sordariomycetes) provides evidence for five new orders and six new families. Fungal Diversity (in press.)

Hyde KD, Chaiwan N, Norphanphoun C, Boonmee S et al. 2018 - Mycosphere notes 169-224. Mycosphere 9, 271-430.

Hyde KD, Fryar S, Tian Q, Bahkali AH, Xu JC. 2016a - Lignicolous freshwater fungi along a north-south latitudinal gradient in the Asian/Australian region; can we predict the impact of global warming on biodiversity and function? Fungal Ecology 19, 190-200.

Hyde KD, Hongsanan S, Jeewon R, Bhat DJ et al. 2016b - Fungal diversity notes 367-490: taxonomic and phylogenetic contributions to fungal taxa. Fungal Diversity 80, 1-270.

Hyde KD, Maharachchikumbura SSN, Hongsanan S, Samarakoon MC et al. 2017 - The ranking of fungi: a tribute to David L. Hawksworth on his 70th birthday. Fungal Diversity 84, 1-23.

Hyde KD, Norphanphoun C, Maharachchikumbura SSN, Bhat DJ et al. 2020 - Refined families of Sordariomycetes. Mycosphere 11, 305-1059. 
Hyde KD, Tennakoon DS, Jeewon R, Bhat DJ et al. 2019 - Fungal diversity notes 1036-1150: taxonomic and phylogenetic contributions on genera and species of fungal taxa. Fungal Diversity 96, 1-242.

Hyde KD, Wong SW, Jones EBG. 1998 - Diluviocola capensis gen. and sp. nov., a freshwater ascomycete with unique polar caps on the ascospores. Fungal Diversity 1, 133-146.

Index Fungorum. 2021 - http://www.indexfungorum.org/names/Names.asp. (Retrieved on January 10, 2021)

Ingold CT. 1942 - Aquatic hyphomycetes of decaying alder leaves. Transactions of the British Mycological Society 25, 339-417.

Ingold CT. 1951 - Aquatic ascomycetes: Ceriospora caudaesuis n.sp. and Ophiobolus typhae. Transactions of the British Mycological Society 34, 210-215.

Ingold CT. 1955 - Aquatic ascomycetes: further species from the English Lake District. Transactions of the British Mycological Society 38, 157-168.

Jayasiri SC, Hyde KD, Ariyawansa HA, Bhat DJ et al. 2015 - The Faces of Fungi database: fungal names linked with morphology, phylogeny and human impacts. Fungal Diversity 74, 3-18.

Jeewon R, Hyde KD. 2016 - Establishing species boundaries and new taxa among fungi: recommendations to resolve taxonomic ambiguities. Mycosphere 7, 1669-1677.

Katoh K, Standley DM. 2016 - A simple method to control over-alignment in the MAFFT multiple sequence alignment program. Bioinformatics 32, 1933-1942.

Khemmuk W, Geering ADW, Shivas RG. 2016 - Wongia gen. nov. (Papulosaceae, Sordariomycetes), a new generic name for two root-infecting fungi from Australia. IMA Fungus 7, 247-252.

Kirk PM. 1982 - New or interesting microfungi VI. Sporidesmiella gen. nov. (Hyphomycetes). Transactions of the British Mycological Society 79, 479-489.

Larget B, Simon DL. 1999 - Markov chain Monte Carlo algorithms for the Bayesian analysis of phylogenetic trees. Molecular Biology and Evolution 16, 750-759.

Liu F, Hu DM, Cai L. 2012 - Canlarium duplumascospora gen. et. sp nov and Jobellisia guangdongensis sp. nov. from freshwater habitats in China. Mycologia 104, 1178-1186.

Liu LL, Yang J, Liu NG, Chen YY et al. 2019 - Sporidesmium guizhouense sp. nov. (Sordariomycetes incertae sedis), a new species from a freshwater habitat in Guizhou Province, China. Phytotaxa 422, 144-156.

Liu YJ, Whelen S, Hall BD. 1999 - Phylogenetic relationships among ascomycetes: evidence from an RNA polymerse II subunit. Molecular Biology and Evolution 16, 1799-1808.

Luo J, Yin J, Cai L, Zhang KQ, Hyde KD. 2004 - Freshwater fungi in Lake Dianchi, a heavily polluted lake in Yunnan, China. Fungal Diversity 16, 93-112.

Luo ZL, Hyde KD, Liu JK, Bhat DJ et al. (2018) Lignicolous freshwater fungi from China II: Novel Distoseptispora (Distoseptisporaceae) species from northwestern Yunnan Province and a suggested unified method for studying lignicolous freshwater fungi. Mycosphere 9, 444461.

Luo ZL, Hyde KD, Liu JK, Maharachchikumbura SSN et al. 2019 - Freshwater Sordariomycetes. Fungal Diversity 99, 451-660.

Luo ZL, Maharachchikumbura SSN, Liu XY, Chen LJ et al. 2015 - Annulatascus saprophyticus sp. nov. and Pseudoannulatascus gen. nov. to accommodate Annulatascus biatriisporus (Annulatascales, Sordariomycetes) from Thailand. Phytotaxa 239, 174-182.

Ma J, Zhang YD, Ma LG, Castañeda-Ruíz RF, Zhang XG. 2012 - Three new species of Sporidesmiella from southern China. Mycoscience 53, 187-193.

Ma LG, Xia JW, Ma YR, Zhang XG. 2014 - Three new species of Pleurophragmium from Yunnan, China. Mycotaxon 127, 213-219.

Maharachchikumbura SSN, Hyde KD, Jones EBG, McKenzie EHC et al. 2016 - Families of Sordariomycetes. Fungal Diversity 79, 1-317.

Maharachchikumbura SSN, Hyde KD, Jones EBG, McKenzie EHC et al. 2015 - Towards a natural classification and backbone tree for Sordariomycetes. Fungal Diversity 72, 199-301. 
Matsushima T. 1971 - Microfungi of the Solomon Islands and Papua-New Guinea. Kobe, Japan 1524.

Miller MA, Pfeiffer W, Schwartz T. 2010 - Creating the CIPRES Science Gateway for inference of large phylogenetic trees. In: Gateway Computing Environments Workshop (GCE), San Diego Supercomput $1-8$.

Miller MA, Schwartz T, Pickett BE, He S et al. 2015 - A RESTful API for access to phylogenetic tools via the CIPRES science gateway. Evolutionary Bioinformatics 11, 43-48.

Monkai J, Boonmee S, Ren GC, Wei DP et al. 2020 - Distoseptispora hydei sp. nov. (Distoseptisporaceae), a novel lignicolous fungus on decaying bamboo in Thailand. Phytotaxa 459, 93-107.

Pem D, Jeewon R, Bhat DJ, Doilom M et al. 2019 - Mycosphere notes 275-324: A morphotaxonomic revision and typification of obscure Dothideomycetes genera (incertae sedis). Mycosphere 10, 1115-1246.

Phookamsak R, Hyde KD, Jeewon R, Bhat DJ et al. 2019 - Fungal diversity notes 929-1035: taxonomic and phylogenetic contributions on genera and species of fungi. Fungal Diversity 95, 1-273.

Pratibha J, Prabhugaonkar A, Hyde KD, Bhat DJ. 2014 - Phylogenetic placement of Bahusandhika, Cancellidium and Pseudoepicoccum (asexual Ascomycota). Phytotaxa 176, 68-80.

Réblová M, Fournier J, Štěpánek V. 2016 - Two new lineages of aquatic ascomycetes: Atractospora gen. nov. and Rubellisphaeria gen. et sp. nov., and a sexual morph of Myrmecridium montsegurinum sp. nov. Mycological Progress 15, 1-18.

Réblová M, Miller AN, Réblová K, Stěpánek V. 2018 - Phylogenetic classification and generic delineation of Calyptosphaeria gen. nov., Lentomitella, Spadicoides and Torrentispora (Sordariomycetes). Studies in Mycology 89, 1-62.

Raja HA, Campbell J, Shearer CA. 2003 - Freshwater ascomycetes: Cyanoannulus petersenii, a new genus and species from submerged wood. Mycotaxon 88, 1-17.

Raja HA, Ferrer A, Shearer CA. 2009 - Freshwater ascomycetes: a new genus, Ocala scalariformis gen. et sp. nov, and two new species, Ayria nubispora sp. nov. and Rivulicola cygnea sp. nov. Fungal Diversity 34, 79-86.

Ranghoo VM, Hyde KD, Liew ECY, Spatafora JW. 1999 - Family placement of Ascotaiwania and Ascolacicola based on DNA sequences from the large subunit rRNA gene. Fungal Diversity 2, 159-168.

Rehner SA, Samuels GJ. 1994 - Taxonomy and phylogeny of Gliocladium analysed from nuclear large subunit ribosomal DNA sequences. Mycological Research 98, 625-634.

Senanayake IC, Rathnayake AR, Marasinghe DS, Calabon MS et al. 2020 - Morphological approaches in studying fungi: collection, examination, isolation, sporulation and preservation. Mycosphere 11, 2678-2754.

Shenoy BD, Jeewon R, Wu WP, Bhat DJ, Hyde KD. 2006 - Ribosomal and RPB2 DNA sequence analyses suggest that Sporidesmium and morphologically similar genera are polyphyletic. Mycological Research 110, 916-928.

Song HY, Huo GH, Hu DM. 2018a - Dictyosporella hydei sp. nov., an asexual species from freshwater habitats in China. Phytotaxa 358, 181-188.

Song HY, Zhong PA, Liao JL, Wang ZH et al. 2018b - Junewangia aquatica (Junewangiaceae), a new species from freshwater habitats in China. Phytotaxa 336, 272-278.

Su HY, Hyde KD, Maharachchikumbura SSN, Ariyawansa HA et al. 2016 - The families Distoseptisporaceae fam. nov., Kirschsteiniotheliaceae, Sporormiaceae and Torulaceae, with new species from freshwater in Yunnan Province, China. Fungal Diversity 80, 375-409.

Su HY, Udayanga D, Luo ZL, Manamgoda DS et al. 2015 - Hyphomycetes from aquatic habitats in Southern China: species of Curvularia (Pleosporaceae) and Phragmocephala (Melannomataceae). Phytotaxa 226, 201-216.

Subramanian CV. 1992 - A reassessment of Sporidesmium (Hyphomycetes) and some related taxa. Proceedings of the Indian National Science Academy B58 4, 179-190. 
Sun YR, Goonasekara ID, Thambugala KM, Jayawardena RS et al. 2020 - Distoseptispora bambusae sp. nov. (Distoseptisporaceae) on bamboo from China and Thailand. Biodiversity Data Journal 8, e53678.

Tibpromma S, Hyde KD, McKenzie EHC, Bhat DJ et al. 2018 - Fungal diversity notes 840-928: micro-fungi associated with Pandanaceae. Fungal Diversity 93, 1-160.

Tsui CKM, Hodgkiss IJ, Hyde KD. 2003 - Three new species of Aquaticola (Ascomycetes) from tropical freshwater habitats. Nova Hedwigia 77, 161-168.

Tubaki K. 1975 - Notes on the Japanese Hyphomycetes. VII. Cancellidium, a new Hyphomycetes genus. Transactions of the Mycological Society of Japan 16, 357-360.

Vijaykrishna D, Jeewon R, Hyde KD. 2006 - Molecular taxonomy, origins and evolution of freshwater ascomycetes. Fungal Diversity 23, 351-390.

Vilgalys R, Hester M. 1990 - Rapid genetic identification and mapping of enzymatically amplified ribosomal DNA from several Cryptococcus species. Journal of Bacteriology 172, 4238-4246.

Wang GN, Yu XD, Dong W, Bhat DJ et al. 2019 - Freshwater hyphomycetes in Eurotiomycetes: a new species of Minimelanolocus and a new collection of Thysanorea papuana (Herpotrichiellaceae). Mycological Progress 18, 511-522.

White TJ, Bruns T, Lee S, Taylor J (1990 - Amplification and direct sequencing of fungal ribosomal RNA genes for phylogenetics. In: Innis MA, Gelfand DH, Sninsky JJ, White TJ (Eds). PCR Protocols: A guide to methods and applications 315-322.

Wijayawardene NN, Hyde KD, Al-Ani LKT, Tedersoo L et al. 2020 - Outline of Fungi and fungus-like taxa. Mycosphere 11, 1060-1456.

Winka K, Eriksson OE. 2000 - Papulosa amerospora accommodated in a new family (Papulosaceae, Sordariomycetes, Ascomycota) inferred from morphological and molecular data. Mycoscience 41, 97-103.

Wong SW, Hyde KD. 1999a - Proboscispora aquatica gen. et sp. nov., from wood submerged in freshwater. Mycological Research 103, 81-87.

Wong SW, Hyde KD, Jones EBG. 1999b - Ultrastructural studies on freshwater ascomycetes, Fluminicola bipolaris gen. et sp. nov. Fungal Diversity 2, 189-197.

Wong SW, Hyde KD, Jones EBG, Moss ST. 1999c - Ultrastructural studies on the aquatic ascomycetes Annulatascus velatisporus and A. triseptatus sp. nov. Mycological Research 103, 561-571.

Xia JW, Ma YR, Li Z, Zhang XG. 2017 - Acrodictys-like wood decay fungi from southern China, with two new families Acrodictyaceae and Junewangiaceae. Scientific Reports 7, 7888.

Xie L, Chen YL, Long YY, Zhang Y et al. 2019 - Three new species of Conlarium from sugarcane rhizosphere in southern China. MycoKeys 56, 1-11.

Yang J, Maharachchikumbura SSN, Hyde KD, Bhat DJ et al. 2015 - Aquapteridospora lignicola gen. et sp nov., a new hyphomycetous taxon (Sordariomycetes) from wood submerged in a freshwater stream. Cryptogamie, Mycologie 36, 469-478.

Yang J, Maharachchikumbura SSN, Liu JK, Hyde KD et al. 2018 - Pseudostanjehughesia aquitropica gen. et sp. nov. and Sporidesmium sensu lato species from freshwater habitats. Mycological Progress 17, 591-616.

Yeung QSY, Jeewon R, Hyde KD. 2006 - Cancellidium pinicola sp. nov. from Pinus massoniana and its phylogeny. Cryptogamie, Mycologie 27, 295-304.

Yu XD, Dong W, Bhat DJ, Boonmee S et al. 2018 - Cylindroconidiis aquaticus gen. et sp nov., a new lineage of aquatic hyphomycetes in Sclerococcaceae (Eurotiornycetes). Phytotaxa 372, 79-87.

Yuan HS, Lu X, Dai YC, Hyde KD et al. 2020 - Fungal diversity notes 1277-1386: taxonomic and phylogenetic contributions to fungal taxa. Fungal Diversity 104, 1-266.

Zelski SE. 2015 - A monograph of the freshwater ascomycete family Annulatascaceae: a morphological and molecular study. Dissertation, University of Illinois.

Zelski SE, Balto JA, Do C, Raja HA et al. 2014 - Phylogeny and morphology of dematiaceous freshwater microfungi from Perú. IMA Fungus 5, 425-438. 
Zelski SE, Raja HA, Miller AN, Barbosa FR et al. 2011 - Longicollum biappendiculatum gen. et sp. nov., a new freshwater ascomycete from the Neotropics. Archives of Physical Medicine \& Rehabilitation 2, 539-545.

Zhang H, Dong W, Hyde KD, Bahkali AH et al. 2016 - Molecular data shows Didymella aptrootii is a new genus in Bambusicolaceae. Phytotaxa 247, 99-108.

Zhang H, Dong W, Hyde KD, Maharachchikumbura SSN et al. 2017 - Towards a natural classification of Annulatascaceae-like taxa: introducing Atractosporales ord. nov. and six new families. Fungal Diversity 85, 75-110.

Zhang H, Hyde KD, Abdel-Wahab MA, Abdel-Aziz FA et al. 2013 - A modern concept for Helicascus with a pleurophomopsis-like asexual state. Sydowia $65,147-166$.

Zhang H, Jones EBG, Zhou DQ, Bahkali AH, Hyde KD. 2011 - Checklist of freshwater fungi in Thailand. Cryptogamie, Mycologie 32, $199-217$. Zhao GZ, Cao AX, Zhang TY, Liu XZ. 2011 - Acrodictys (Hyphomycetes) and related genera from China. Mycological Progress 10, 67-83.

Supplementary Table 1 Taxa used in the phylogenetic analyses and their corresponding GenBank accession numbers

\begin{tabular}{|c|c|c|c|c|c|}
\hline \multirow{2}{*}{ Taxon } & \multirow{2}{*}{ Voucher/Culture } & \multicolumn{4}{|c|}{ GenBank accession numbers } \\
\hline & & LSU & ITS & TEF & RPB2 \\
\hline Acrodictys aquatica & MFLUCC 18-0356 & MG835712 & MG835711 & - & - \\
\hline Acrodictys bambusicola & HSAUPmyr 9510 & KX033564 & KU999973 & - & - \\
\hline Acrodictys elaeidicola & HSAUPmj 5528 & KX033569 & KU999978 & - & - \\
\hline Acrodictys elaeidicola & HSAUPmj 5536 & KX033568 & KU999977 & - & - \\
\hline Acrodictys globulosa & HSAUPmyr 4696 & KX033562 & KU999970 & - & - \\
\hline Acrodictys hainanensis & HSAUPmyr 7561 & KX033565 & KU999974 & - & - \\
\hline Acrodictys liputii & HSAUPmj 1883 & KX033570 & KU999979 & - & - \\
\hline Acrodictys liputii & HSAUPmlg 2137 & KX033558 & KU999966 & - & - \\
\hline Acrodictys malabarica & HSAUPmyr 9509 & KX033560 & KU999968 & - & - \\
\hline Acrodictys peruamazonensis & HSAUPmyr 4694 & KX033561 & KU999969 & - & - \\
\hline Acrodictys porosiseptata & HSAUPmyr 4698 & KX033559 & KU999967 & - & - \\
\hline Acrodictys porosiseptata & MFLUCC 11-0299 & MW287761 & MW286488 & - & - \\
\hline Acrodictys fuminicola & KUMCC 15-0240 & MK849786 & MK828642 & - & - \\
\hline Amplistroma caroliniana & BEO9923 & FJ532377 & - & - & - \\
\hline Amplistroma erinaceum & AH 43902 & NG_058568 & - & - & - \\
\hline Amplistroma guianensis & GJS5740 & FJ53̄2380 & - & - & - \\
\hline Annulatascus chiangmaiensis & $\underline{\text { MFLUCC 17-2346 }}$ & MW287764 & MW286490 & - & - \\
\hline Annulatascus hongkongensis & $\overline{\text { HKUCC } 3702}$ & $\overline{\text { AF132319 }}$ & - & & - \\
\hline Annulatascus nakhonensis & MFLUCC 18-1239 & MW287779 & $\bar{M} W 286505$ & MW396650 & - \\
\hline$\overline{\text { Annulatascus saprophyticus }}$ & $\overline{\text { MFLUCC 14-0035 }}$ & $\overline{\text { KR868947 }}$ & & & - \\
\hline Annulatascus songkhlaensis & MFLUCC 18-1151 & MW287754 & $\bar{M} W 286483$ & MW396644 & - \\
\hline Annulatascus thailandensis & $\overline{\text { MFLUCC 18-1248 }}$ & $\overline{\text { MN733254 }}$ & $\overline{\text { MN733256 }}$ & & - \\
\hline
\end{tabular}


Supplementary Table 1 Continued.

\begin{tabular}{|c|c|c|c|c|c|}
\hline \multirow{2}{*}{ Taxon } & \multirow{2}{*}{ Voucher/Culture } & \multicolumn{4}{|c|}{ GenBank accession numbers } \\
\hline & & LSU & ITS & TEF & RPB2 \\
\hline Annulatascus velatisporus & MFLUCC 16-1441 & KY244031 & KY320183 & - & - \\
\hline Annulatascus velatisporus & MFLU 16-2204 & KX772397 & KX772399 & - & - \\
\hline Annulusmagnus triseptatus & MFLUCC 17-0469 & MK849801 & MK828655 & $\bar{M} 194059$ & - \\
\hline Annulusmagnus triseptatus & MFLUCC 17-0462 & MK849800 & MK828654 & MN194058 & - \\
\hline Annulusmagnus triseptatus & MFLUCC 18-1335 & MK849799 & MK828653 & MN194057 & MN124539 \\
\hline Annulusmagnus triseptatus & CBS 127688 & MH876116 & MH864680 & - & - \\
\hline Annulusmagnus triseptatus & CBS 127687 & MH876115 & MH864679 & - & - \\
\hline Annulusmagnus triseptatus & CBS 128831 & GQ996540 & - & - & JQ429258 \\
\hline Annulusmagnus triseptatus & M.R. 2948 & GQ996540 & - & - & - \\
\hline Annulusmagnus triseptatus & SMH4832 & AY780049 & - & - & - \\
\hline Annulusmagnus triseptatus & A353-1F & AY590289 & - & - & - \\
\hline Annulusmagnus triseptatus & A325-1D & AY590288 & - & - & - \\
\hline Annulusmagnus triseptatus & A $413-6$ & AY590285 & - & - & - \\
\hline Annulusmagnus triseptatus & SMH2359 & AY346257 & - & - & AY780148 \\
\hline Aquafiliformis lignicola & MFLUCC 16-1341 & MK835815 & MK828615 & MN194068 & MN156511 \\
\hline Aquafiliformis lignicola & MFLUCC 18-1338 & MK835814 & MK828614 & MN194067 & MN156510 \\
\hline Aquapteridospora aquatica & MFLUCC 17-2371 & MW287767 & MW286493 & - & - \\
\hline$\overline{\text { Aquapteridospora fusiformis }}$ & $\overline{\text { MFLU 18-1601 }}$ & $\overline{\text { MK849798 }}$ & $\overline{\mathrm{MK828652}}$ & MN194056 & - \\
\hline Aquapteridospora lignicola & MFLU 15-1172 & KU221018 & - & - & - \\
\hline Aquidictyomyces appendiculatus & KUMCC 19-0061 & MW287756 & - & - & - \\
\hline$\overline{\text { Arecophila bambusae }}$ & $\overline{\text { HKUCC } 4794}$ & $\overline{\mathrm{AF} 452038}$ & - & - & - \\
\hline Ascitendus aquaticus & MR 150 & MG813818 & - & - & - \\
\hline Ascitendus austriacus & MFLUCC 16-1345 & MK849802 & - & $\overline{\mathrm{MN}} 194060$ & - \\
\hline Ascitendus austriacus & CBS 131685 & GQ996539 & - & - & JQ429257 \\
\hline Ascitendus austriacus & M.R. 2936 & GQ996539 & - & - & - \\
\hline Ascitendus austriacus & A324-1F & AY590294 & - & - & - \\
\hline Ascitendus austriacus & A44-28A & AY590292 & - & - & - \\
\hline Atractospora aquatica & S-1297 & MK849849 & $\overline{\mathrm{MK}} 828697$ & $\overline{\mathrm{MN}} 194039$ & $\overline{M N} 124528$ \\
\hline Atractospora aquatica & MFLU 18-2322 & MK849848 & MK828696 & MN194038 & MN124527 \\
\hline Atractospora decumbens & CBS 139032 & KT991658 & NR153541 & - & KT991647 \\
\hline Atractospora ellipsoidea & R 008 & AY590290 & - & - & - \\
\hline Atractospora ellipsoidea & A411-3 & AY316356 & - & - & - \\
\hline Atractospora ellipsoidea & KUMCC 18-0051 & MW287772 & MW286498 & MW396655 & MW504071 \\
\hline Atractospora reticulata & CBS 138740 & KT991661 & KT991670 & - & KT991650 \\
\hline Atractospora reticulata & CBS 127884 & KT991660 & KT991669 & & KT991649 \\
\hline
\end{tabular}


Supplementary Table 1 Continued.

\begin{tabular}{|c|c|c|c|c|c|}
\hline \multirow{2}{*}{ Taxon } & \multirow{2}{*}{ Voucher/Culture } & \multicolumn{4}{|c|}{ GenBank accession numbers } \\
\hline & & LSU & ITS & TEF & RPB2 \\
\hline Atractospora thailandensis & KUMCC 16-0067 & MF374362 & MF374353 & MF370962 & MF370951 \\
\hline Atractospora verruculosa & CBS 132040 & KT991659 & КT991668 & - & KT991648 \\
\hline Aureobasidium pullulans & CBS 584.75 & DQ470956 & - & $\overline{\mathrm{D} Q 471075}$ & DQ470906 \\
\hline Barbatosphaeria barbirostris & MR3767 & KM492863 & $\overline{\mathrm{K}} \mathrm{M} 492888$ & - & KM492902 \\
\hline Barbatosphaeria barbirostris & CBS 121149 & EF577059 & - & - & KM492903 \\
\hline Barbatosphaeria lignicola & HKAS 84005 & MK849791 & $\overline{\mathrm{MK}} \mathbf{8 2 8 6 4 6}$ & $\overline{M N 194050}$ & - \\
\hline Barbatosphaeria neglecta & CBS 127693 & KM492868 & KM492895 & _ & - \\
\hline Barbatosphaeria varioseptata & CBS 137797 & KM492869 & KM492896 & - & $\overline{\text { KM492907 }}$ \\
\hline Brachysporium nigrum & MR 1346 & KT991662 & - & - & KT991652 \\
\hline Brunneosporella aquatica & HKUCC 3708 & AF132326 & $\overline{\mathrm{AF}} 177154$ & - & - \\
\hline Bullimyces aurisporus & AF316-1b & JF775590 & - & - & - \\
\hline Bullimyces communis & AF281-5 & JF775587 & - & - & - \\
\hline Bullimyces costaricensis & AF317-1a & JF775591 & - & - & - \\
\hline Calyptosphaeria subdenudata & SMH 3877 & EU527994 & $\overline{\mathbf{K} Y 931774}$ & - & - \\
\hline Calyptosphaeria subdenudata & SMH 2534 & EU527993 & KY931775 & - & - \\
\hline Calyptosphaeria tenebrosa & PRA 12740 & KY931810 & KY931778 & - & KY931837 \\
\hline Calyptosphaeria tenebrosa & PRA 12741 & KY931809 & KY931777 & - & KY931836 \\
\hline Camarops microspora & CBS 649.92 & AY083821 & - & $\overline{\mathrm{D} Q 471108}$ & DQ470937 \\
\hline Cancellidium applanatum & ILL 41205 & KF833360 & - & - & - \\
\hline Cancellidium applanatum & CBS 137655 & KF833359 & - & - & - \\
\hline Cancellidium applanatum & CBS 337.76 & NG_064107 & MH860985 & - & - \\
\hline Cancellidium atrobrunneum & GUFCC 18002 & KF 460276 & KF460275 & - & - \\
\hline Cancellidium atrobrunneum & MFLUCC 20-0100 & MT422740 & MT422724 & MT436438 & - \\
\hline Cancellidium atrobrunneum & MFLUCC 17-2361 & MW287769 & MW286495 & - & - \\
\hline Cancellidium cinereum & MFLUCC 18-0424 & MT370363 & MT370353 & MT370488 & MT370486 \\
\hline Cancellidium griseonigrum & MFLUCC 17-2117 & MT370364 & MT370354 & - & MT370487 \\
\hline Cancellidium griseonigrum & MFLUCC 18-1236 & MW287782 & MW286481 & MW396653 & - \\
\hline Cancellidium thailandense & $\underline{\text { MFLUCC 18-1142 }}$ & MW287757 & MW286485 & - & - \\
\hline$\overline{\text { Cataractispora receptaculorum }}$ & $\overline{\text { HKUCC } 3710}$ & $\overline{\mathrm{AF} 132327}$ & $\overline{-}$ & - & - \\
\hline Ceratolenta caudata & PRM 899855 & JX066705 & - & - & - \\
\hline Ceratolenta caudata & CBS 125234 & JX066704 & - & - & $\bar{J} X 066699$ \\
\hline Ceratosphaeria aquatica & MFLUCC 18-1337 & MK835812 & MK828612 & MN194065 & MN156509 \\
\hline Ceratosphaeria lampadophora & CBS 117555 & AY761084 & - & _ & _ \\
\hline Ceratosphaeria lignicola & MFLUCC 18-0342 & MK835813 & МK828613 & MN194066 & - \\
\hline Ceratostomella cuspidata & ICMP 17629 & FJ617558 & KT991671 & & КT991651 \\
\hline
\end{tabular}


Supplementary Table 1 Continued.

\begin{tabular}{|c|c|c|c|c|c|}
\hline \multirow{2}{*}{ Taxon } & \multirow{2}{*}{ Voucher/Culture } & \multicolumn{4}{|c|}{ GenBank accession numbers } \\
\hline & & LSU & ITS & TEF & RPB2 \\
\hline Ceratostomella pyrenaica & CBS 117116 & DQ076323 & & - & - \\
\hline Chloridium gonytrichii & MFLU 11-1051 & MH476568 & МH476571 & - & - \\
\hline Conlarium aquaticum & MFLUCC 18-0338 & MK849850 & MK828698 & - & - \\
\hline Conlarium aquaticum & MFLUCC 15-0992 & MF374363 & MF374354 & MF370963 & - \\
\hline Conlarium aquaticum & MFLUCC 18-1417 & MW287759 & MW286486 & MW396645 & - \\
\hline Conlarium baiseense & TD17 & MK164655 & MK164653 & - & MK572999 \\
\hline Conlarium baiseense & TD2 & MF083158 & MF083157 & - & MK573000 \\
\hline Conlarium duplumascospora & CGMCC 3.14940 & JN936993 & JN936997 & - & - \\
\hline Conlarium duplumascospora & CGMCC 3.14939 & JN936992 & JN936996 & - & - \\
\hline Conlarium duplumascospora & CGMCC 3.14938 & JN936991 & JN936995 & - & - \\
\hline Conlarium nanningense & M8 & MK164656 & MK164654 & - & MK572998 \\
\hline Conlarium nanningense & M1 & KX886202 & KX886204 & - & MK224589 \\
\hline Conlarium sacchari & DX4 & MF083167 & MF083166 & - & MK224587 \\
\hline Conlarium sacchari & LA3 & MF083164 & MF083163 & - & MK573001 \\
\hline Conlarium sacchari & NN1 & MF083161 & MF083160 & - & MK224588 \\
\hline Conlarium subglobosum & $\underline{\text { MFLU 17-1728 }}$ & MW287768 & MW286494 & - & - \\
\hline$\overline{\text { Conlarium thailandense }}$ & $\overline{\text { MFLUCC 17-2349 }}$ & $\overline{\text { МH624127 }}$ & $\overline{\text { MH624129 }}$ & & - \\
\hline Cosmospora arxii & CBS 748.69 & MH871181 & NR_145062 & $\overline{\mathrm{K}} \mathrm{2} 231950$ & HQ8977725 \\
\hline Cryphonectria parasitica & CMW 7048 & JN940858 & - & - & - \\
\hline Cryptadelphia groenendalensis & SH12 & EU528007 & - & - & - \\
\hline Cryptadelphia groenendalensis & SMH 3767 & EU528001 & - & - & - \\
\hline Cryptadelphia polyseptata & MR1668 & AY281102 & - & - & - \\
\hline Cyanoannulus petersenii & $\mathrm{R} 044 \mathrm{~b}$ & AY316359 & - & - & - \\
\hline Cyanoannulus petersenii & R 044a & AY316358 & - & & - \\
\hline Cytospora elaeagni & CFCC 89633 & KF765693 & - & $\bar{K} U 710919$ & $\bar{K} U 710956$ \\
\hline Diaporthe cyatheae & YMJ 1364 & JX570891 & - & JX570892 & JX570893 \\
\hline Diaporthe eres & AR 3538 & AF408350 & - & - & - \\
\hline Diaporthe xishuangbanica & LC6744 & KY011862 & - & KX999176 & - \\
\hline Dictyosporella aquatica & CBS H-22127 & KT241022 & - & - & - \\
\hline Dictyosporella chiangmaiensis & $\underline{\text { MFLUCC 17-2345 }}$ & $\underline{\text { MW287765 }}$ & $\underline{\text { MW286491 }}$ & - & - \\
\hline Dictyosporella ellipsoidea & MFLUCC 18-1042 & MW287758 & - & - & - \\
\hline$\overline{\text { Dictyosporella guizhouensis }}$ & MFLU 18-1505 & $\overline{\text { MK593605 }}$ & MK593606 & & - \\
\hline Dictyosporella guizhouensis & MFLUCC 18-1232 & MW287760 & MW286487 & MW396646 & - \\
\hline Dictyosporella hydei & IFRDCC 3075 & MG813161 & - & - & \\
\hline Dictyosporella thailandensis & MFLUCC 15-0985 & MF374364 & MF374355 & MF370958 & MF370952 \\
\hline
\end{tabular}


Supplementary Table 1 Continued.

\begin{tabular}{|c|c|c|c|c|c|}
\hline \multirow{2}{*}{ Taxon } & \multirow{2}{*}{ Voucher/Culture } & \multicolumn{4}{|c|}{ GenBank accession numbers } \\
\hline & & LSU & ITS & TEF & RPB2 \\
\hline Diluviicola capensis & KUMCC 19-0088 & MW287777 & MW286503 & MW396647 & - \\
\hline Diluviicola capensis & KUMCC 19-0089 & MW287776 & MW286502 & MW396648 & - \\
\hline Disculoides eucalyptorum & CPC 17648 & JQ685524 & - & - & - \\
\hline Distoseptispora adscendens & HKUCC 10820 & DQ408561 & - & - & $\bar{D} Q 435092$ \\
\hline Distoseptispora appendiculata & B-95 & MN163023 & $\overline{M N 163009}$ & - & - \\
\hline Distoseptispora aquatica & MFLUCC 16-1357 & MK849796 & MK828650 & $\overline{\mathrm{MN}} 194055$ & \\
\hline Distoseptispora aquatica & MFLUCC 16-1254 & MK849795 & - & MN194054 & MN124538 \\
\hline Distoseptispora aquatica & MFLUCC 16-0904 & MK849794 & $\overline{\mathrm{MK}} 828649$ & MN194053 & - \\
\hline Distoseptispora aquatica & MFLUCC 18-0646 & MK849793 & MK828648 & MN194052 & - \\
\hline Distoseptispora aquatica & S-965 & MK849792 & MK828647 & MN194051 & $\overline{M N} 124537$ \\
\hline Distoseptispora aquatica & MFLUCC 15-0374 & KU376268 & 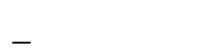 & ( & \\
\hline Distoseptispora bambusae & MFLUCC 20-0091 & MT232718 & $\overline{\mathbf{M T} 232713}$ & $\overline{\mathrm{MT} 232880}$ & $\overline{\text { MT232881 }}$ \\
\hline Distoseptispora cangshanensis & MFLUCC 16-0970 & MG979761 & MG979754 & MG988419 & - \\
\hline Distoseptispora caricis & CPC 36498 & MN567632 & MN562124 & - & MN556805 \\
\hline Distoseptispora caricis & CPC 36442 & - & MN562125 & - & MN556806 \\
\hline Distoseptispora clematidis & MFLUCC 17-2145 & $\overline{\mathrm{MT}} 214617$ & MT310661 & - & MT394721 \\
\hline Distoseptispora dehongensis & KUMCC 18-0090 & МK079662 & MK085061 & МK087659 & - \\
\hline Distoseptispora fasciculata & $\underline{\text { KUMCC 19-0081 }}$ & MW287775 & MW286501 & MW396656 & - \\
\hline$\overline{\text { Distoseptispora fluminicola }}$ & $\overline{\text { MFLUCC 15-0417 }}$ & $\overline{\text { KU376270 }}$ & $\overline{\text { NR_154041 }}$ & $\overline{-}$ & - \\
\hline Distoseptispora guttulata & B43 & MN163016 & MN163011 & - & - \\
\hline Distoseptispora guttulata & MFLUCC 16-0183 & MF077554 & MF077543 & - & - \\
\hline Distoseptispora hydei & MFLUCC 20-0481 & MT742830 & MT734661 & - & МT767128 \\
\hline Distoseptispora leonensis & HKUCC 10822 & DQ408566 & - & - & DQ435089 \\
\hline Distoseptispora lignicola & MFLUCC 18-0198 & MK849797 & MK828651 & - & _ \\
\hline Distoseptispora longispora & HFJAU 0705 & MH555357 & MH555359 & - & - \\
\hline Distoseptispora multiseptata & B37 & MN163013 & - & - & - \\
\hline Distoseptispora multiseptata & MFLUCC 16-1044 & MF077555 & MF077544 & - & - \\
\hline Distoseptispora multiseptata & MFLUCC 15-0609 & KX710140 & NR_154017 & - & - \\
\hline Distoseptispora neorostrata & B103 & MN163017 & MN163008 & - & - \\
\hline Distoseptispora obclavata & B71 & MN163010 & MN163012 & - & - \\
\hline Distoseptispora obpyriformis & DLUCC 0867 & MG979765 & MG979757 & MG988423 & MG988416 \\
\hline Distoseptispora obpyriformis & MFLUCC 17-1694 & MG979764 & - & MG988422 & MG988415 \\
\hline Distoseptispora palmarum & MFLUCC 18-1446 & МK079663 & МK085062 & MK087660 & MK087670 \\
\hline Distoseptispora phangngaensis & MFLUCC 16-0857 & MF077556 & _ & - & - \\
\hline Distoseptispora rayongensis & MFLUCC 18-0417 & MH457138 & MH457173 & MH463254 & MH463256 \\
\hline
\end{tabular}


Supplementary Table 1 Continued.

\begin{tabular}{|c|c|c|c|c|c|}
\hline \multirow{2}{*}{ Taxon } & \multirow{2}{*}{ Voucher/Culture } & \multicolumn{4}{|c|}{ GenBank accession numbers } \\
\hline & & LSU & ITS & TEF & RPB2 \\
\hline Distoseptispora rayongensis & MFLUCC 18-0415 & MH457137 & MH457172 & MH463253 & MH463255 \\
\hline Distoseptispora rostrata & DLUCC 0885 & MG979767 & MG979759 & MG988425 & - \\
\hline Distoseptispora rostrata & MFLUCC 16-0969 & MG979766 & MG979758 & MG988424 & MG988417 \\
\hline Distoseptispora saprophytica & MFLUCC 18-1238 & MW287780 & MW286506 & MW396651 & MW504069 \\
\hline$\overline{\text { Distoseptispora songkhlaensis }}$ & $\overline{\text { MFLUCC 18-1234 }}$ & $\overline{\text { MW287755 }}$ & $\overline{\text { MW286482 }}$ & $\overline{\text { MW396642 }}$ & $\overline{-}$ \\
\hline Distoseptispora suoluoensis & $\overline{\text { MFLUCC } 17-1305}$ & $\overline{\mathrm{MF} 077558}$ & $\overline{\mathrm{MF} 077547}$ & $\overline{-}$ & - \\
\hline Distoseptispora suoluoensis & MFLUCC 17-0224 & MF077557 & MF077546 & - & - \\
\hline Distoseptispora tectonae & MFLUCC 12-0291 & KX751713 & KX751711 & KX751710 & $\bar{K} \times 751708$ \\
\hline Distoseptispora tectonae & MFLUCC 20-0090 & MT232719 & MT232714 & - & - \\
\hline Distoseptispora tectonae & MFLUCC 15-0981 & MW287763 & MW286489 & MW396641 & - \\
\hline Distoseptispora tectonae (synonym $D$. submersa) & MFLUCC 16-0946 & MG979768 & MG979760 & MG988426 & MG988418 \\
\hline Distoseptispora tectonigena & MFLUCC 12-0292 & KX751714 & KX751712 & _ & KX751709 \\
\hline Distoseptispora thailandica & MFLUCC 16-0270 & МH260292 & МH275060 & МH412767 & - \\
\hline Distoseptispora thysanolaenae & HKAS 102247 & MK064091 & MK045851 & MK086031 & - \\
\hline Distoseptispora xishuangbannaensis & KUMCC 17-0290 & MH260293 & MH275061 & MH412768 & $\overline{\mathrm{MH}} 412754$ \\
\hline Dothidea insculpta & CBS 189.58 & DQ247802 & - & DQ471081 & AF107800 \\
\hline Entosordaria perfidiosa & BW3 & MF488992 & - & MF489011 & MF489002 \\
\hline Fluminicola aquatica & MFLUCC 15-0962 & MF374366 & - & MF370960 & - \\
\hline Fluminicola saprophytica (synonym $F$. thailandensis) & MFLUCC 18-0199 & MK849790 & - & - & MN124535 \\
\hline Fluminicola saprophytica (synonym $F$. thailandensis) & MFLUCC 14-0037 & MK849789 & MK828644 & MN194049 & - \\
\hline Fluminicola saprophytica (synonym $F$. thailandensis) & MFLUCC 15-0984 & MF374368 & MF374359 & - & - \\
\hline Fluminicola saprophytica & MFLUCC 15-0976 & MF374367 & MF374358 & MF370956 & - \\
\hline Fluminicola saprophytica & MFLUCC 18-1244 & MW287778 & MW286504 & MW396649 & - \\
\hline Fluminicola striata & MFLUCC 18-0990 & MW287770 & MW286496 & - & - \\
\hline$\overline{\text { Fragosphaeria purpurea }}$ & $\overline{\text { CBS } 133.34}$ & AB189154 & $\overline{-}$ & - & - \\
\hline Fusicolla aquaeductuum & KUMCC 18-0015 & MH087221 & МH087219 & - & - \\
\hline Fusoidigranularius nilensis & IMI 397966 & HQ616536 & - & - & - \\
\hline Gnomonia gnomon & CBS 199.53 & AF408361 & - & EU221885 & EU219295 \\
\hline Jattaea algeriensis & STEU 6201 & EU367456 & EU367446 & - & - \\
\hline Jattaea mookgoponga & STEU 6184 & EU367458 & - & - & - \\
\hline Junewangia aquatica & HFJAU 0700 & MG213737 & MG213738 & - & - \\
\hline Junewangia globulosa & CBS 126093 & MH875535 & MH864078 & - & - \\
\hline Junewangia lamma & HSAUPH 4695 & KU751883 & KU999971 & - & - \\
\hline Junewangia lamma & HMAS 44438 & KU751882 & KU999961 & - & - \\
\hline Junewangia queenslandica & HSAUPmyr 7722 & KX033575 & KU999984 & - & - \\
\hline
\end{tabular}


Supplementary Table 1 Continued.

\begin{tabular}{|c|c|c|c|c|c|}
\hline \multirow{2}{*}{ Taxon } & \multirow{2}{*}{ Voucher/Culture } & \multicolumn{4}{|c|}{ GenBank accession numbers } \\
\hline & & LSU & ITS & TEF & RPB2 \\
\hline Junewangia sphaerospora & HSAUPmyr 4733 & KX033572 & KU999981 & - & - \\
\hline Junewangia thailandica & MFLU 15-2682 & MW287762 & - & - & \\
\hline$\overline{\text { Lentomitella conoidea }}$ & $\overline{\mathrm{CBS}} 141370$ & $\overline{\text { KY931813 }}$ & KY931784 & - & KY931841 \\
\hline Lentomitella conoidea & CBS 131660 & KY931812 & KY931783 & - & KY931840 \\
\hline Lentomitella magna & ICMP 18371 & KY931815 & KY931786 & - & KY931843 \\
\hline Lentomitella tenuirostris & CBS 138734 & KY931821 & KY931792 & - & KY931849 \\
\hline Linkosia multiseptum & HKUCC 10825 & DQ408572 & - & - & DQ435091 \\
\hline Longicollum biappendiculatum & PE0017-1b & KU975072 & - & - & - \\
\hline Longicollum biappendiculatum & PE0017-1a & KU975071 & $\overline{\mathbf{K U}} 975062$ & - & - \\
\hline Longivarius aquatorbae & SS 2424 & JN226107 & - & - & - \\
\hline Macrohilum eucalypti & CPC 10945 & DQ195793 & - & - & - \\
\hline Melanconis stilbostoma & AR3501 & AF408374 & - & EU221886 & EU219299 \\
\hline Mirannulata samuelsii & smh1880 & AY578353 & - & - & - \\
\hline Myrmecridium aquaticum & S-001 & MK849805 & MK828657 & - & - \\
\hline Myrmecridium aquaticum & MFLUCC 15-0366 & MK849804 & MK828656 & - & - \\
\hline Myrmecridium aquaticum & S-1158 & MK849803 & - & MN194061 & MN124540 \\
\hline Myrmecridium banksiae & CPC 19852 & JX069855 & JX069871 & - & - \\
\hline Myrmecridium montsegurinum & JF13180 & KT991664 & KT991674 & - & KT991654 \\
\hline Myrmecridium schulzeri & CBS 100.54 & EU041826 & EU041769 & - & - \\
\hline Myrmecridium sorbicola & CBS 143433 & МH107948 & МH107901 & - & - \\
\hline Natantiella ligneola & CBS 123470 & FJ617556 & КТ991675 & - & HQ878605 \\
\hline Natantiella ligneola & CBS 123410 & FJ617555 & KM492899 & - & KM492909 \\
\hline Nectria nigrescens & AR 4211 & HM484720 & HM484707 & HM484672 & JQ014123 \\
\hline Neodiluvicola aquatica & MFLUCC 15-0986 & MF374365 & - & MF370961 & MF370953 \\
\hline Neoeriomycopsis aristata & CPC 25050 & KR476776 & - & - & - \\
\hline Obliquiminima hyalina & MFLUCC 18-1235 & MW287783 & MW286480 & MW396643 & - \\
\hline$\overline{\text { Obliquiminima hyalina }}$ & $\overline{\text { MFLUCC 18-1401 }}$ & $\overline{\text { MW287781 }}$ & $\overline{\text { MW286507 }}$ & $\overline{\text { MW396652 }}$ & - \\
\hline$\overline{\text { Ophiostoma piliferum }}$ & $\overline{\text { AFTOL-ID } 910}$ & $\overline{\mathrm{DQ} 470955}$ & $\overline{-}$ & $\overline{\mathrm{DQ} 471074}$ & DQ470905 \\
\hline Ophiostoma stenoceras & AFTOL-ID 1038 & DQ836904 & - & - & DQ836891 \\
\hline Paoayensis lignicola & HKU 17516 & EF622535 & - & - & - \\
\hline Papulosa amerospora & AFTOL-ID 748 & DQ470950 & - & DQ471069 & DQ470901 \\
\hline Paracremonium binnewijzendii & CBS 143277 & MG250174 & NR_157491 & - & - \\
\hline Phaeoacremonium fraxinopennsylvanicum & MR 3064 & HQ878595 & - & - & HQ878609 \\
\hline Phaeoacremonium fraxinopennsylvanicum & ATCC 26664 & AY761083 & - & - & - \\
\hline Phaeoacremonium novae-zealandiae & WIN113BI & AY761081 & & - & - \\
\hline
\end{tabular}


Supplementary Table 1 Continued.

\begin{tabular}{|c|c|c|c|c|c|}
\hline \multirow{2}{*}{ Taxon } & \multirow{2}{*}{ Voucher/Culture } & \multicolumn{4}{|c|}{ GenBank accession numbers } \\
\hline & & LSU & ITS & TEF & RPB2 \\
\hline Phialemoniopsis endophytica & ACCC 38980 & KT799560 & - & - & - \\
\hline Phialemoniopsis endophytica & ACCC 38979 & KT799559 & - & - & - \\
\hline Phomatospora bellaminuta & AFTOL-ID 766 & FJ176857 & - & - & $\bar{F} \mathbf{F} 238345$ \\
\hline Phomatospora biseriata & MFLUCC 14-0832 & KX549448 & - & - & - \\
\hline Phomatospora striatigera & CBS 133932 & KM213618 & - & - & - \\
\hline Phomatospora viticola & MFLU 16-1973 & KX549452 & - & - & - \\
\hline Phyllachora graminis & TH544 & KX430508 & - & - & - \\
\hline Physalospora vaccinii & CBS 302.53 & DQ810232 & - & - & - \\
\hline Platytrachelon abietis & CBS 125235 & JX066703 & - & - & $\bar{J} X 066698$ \\
\hline Pleurophragmium bambusinum & MFLUCC 12-0850 & KU863149 & $\overline{\text { KUU940161 }}$ & $\overline{\text { KU940213 }}$ & - \\
\hline Pleurothecium aquaticum & MFLUCC 17-1331 & MF399263 & MF399245 & - & - \\
\hline Pleurothecium semifecundum & CBS 131271 & JQ429240 & - & - & JQ429270 \\
\hline Podosordaria tulasnei & CBS 128.80 & KT281897 & - & - & - \\
\hline Pseudoconlarium punctiform & MFLU 19-2855 & MN897833 & - & - & - \\
\hline Pseudoplagiostoma eucalypti & CBS 124807 & GU973606 & - & - & - \\
\hline Pseudoproboscispora caudae-suis & A336-2D & AY094192 & - & - & - \\
\hline Pseudoproboscispora caudae-suis & A40-1A & AY094191 & - & - & - \\
\hline Pseudoproboscispora thailandensis & MFLUCC 15-0989 & MF374369 & - & $\overline{M F 370959}$ & - \\
\hline Pseudoproboscisporaceae sp. & $\mathrm{R}-038$ & AY590291 & - & - & - \\
\hline Pseudostanjehughesia aquitropica & MFLUCC 16-0569 & MF077559 & - & - & - \\
\hline Pseudostanjehughesia lignicola & MFLUCC 15-0352 & MK849787 & MK828643 & MN194047 & MN124534 \\
\hline Rhamphoria delicatula & MR1396 & AF261068 & - & - & KT991655 \\
\hline Rhamphoria pyriformis & CBS 139033 & KT991665 & - & - & KT991656 \\
\hline Rhexoacrodictys martinii & myr4280 & KX033566 & KU999975 & - & - \\
\hline Rhodoveronaea aquatica & MFLUCC 18-1339 & MK849785 & MK828641 & MN194046 & - \\
\hline Rhodoveronaea varioseptata & CBS 123473 & FJ617560 & KT991676 & - & $\bar{J} X 066700$ \\
\hline Rhodoveronaea varioseptata & CBS 123472 & FJ617559 & MG600393 & - & JX066701 \\
\hline Riomyces rotundus & AF 303-1 & JF775589 & - & - & _ \\
\hline Rubellisphaeria abscondita & CBS 132078 & KT991666 & NR154424 & - & КT991657 \\
\hline Savoryella aquatica & SS00096 & HQ446369 & - & HQ446323 & HQ446402 \\
\hline Savoryella verrucosa & SS03331 & HQ446376 & - & HQ446332 & HQ446411 \\
\hline Schizoparme straminea & STEU 3932 & AY339296 & - & - & - \\
\hline Sporidesmiella aquatica & DLUCC 1339 & MK849844 & - & MN194035 & MN124524 \\
\hline Sporidesmiella aquatica & DLUCC 0777 & MK849843 & MK828692 & MN194034 & _- \\
\hline Sporidesmiella hyalosperma & S-1518 & MK849842 & MK828691 & MN194033 & MN124523 \\
\hline
\end{tabular}


Supplementary Table 1 Continued.

\begin{tabular}{|c|c|c|c|c|c|}
\hline \multirow{2}{*}{ Taxon } & \multirow{2}{*}{ Voucher/Culture } & \multicolumn{4}{|c|}{ GenBank accession numbers } \\
\hline & & LSU & ITS & TEF & RPB2 \\
\hline Sporidesmiella hyalosperma & KUMCC 15-0431 & MK849841 & MK828690 & MN194032 & MN124522 \\
\hline Sporidesmiella hyalosperma & S-1320 & MK849840 & MK828689 & - & MN124521 \\
\hline Sporidesmiella hyalosperma & MFLUCC 18-1312 & MK849839 & MK828688 & MN194031 & MN124520 \\
\hline Sporidesmiella hyalosperma & MFLUCC 18-1013 & MW287773 & MW286499 & MW396654 & MW504070 \\
\hline Sporidesmiella novae-zelandiae & S-951 & MK849847 & MK828695 & MN194037 & MN124526 \\
\hline Sporidesmiella novae-zelandiae & $\mathrm{S}-048$ & MK849846 & MK828694 & - & - \\
\hline Sporidesmiella novae-zelandiae & S-1256 & MK849845 & MK828693 & MN194036 & MN124525 \\
\hline Sporidesmiella obovoidia & MFLUCC 17-2372 & MW287766 & MW286492 & - & - \\
\hline$\overline{\text { Sporidesmium appendiculatum }}$ & MFLU 18-0981 & $\overline{\text { MW287774 }}$ & $\overline{\text { MW286500 }}$ & - & - \\
\hline Sporidesmium aquaticum & $\overline{\text { MFLUCC 15-0420 }}$ & $\overline{\text { KU376273 }}$ & $\overline{-}$ & - & - \\
\hline Sporidesmium bambusicola & HKUCC 3578 & DQ408562 & - & - & - \\
\hline Sporidesmium chiangmaiense & MFLUCC 18-0999 & MW287771 & MW286497 & - & - \\
\hline Sporidesmium dulongense & MFLUCC 17-0116 & MH795817 & MH795812 & $\overline{\text { MH801191 }}$ & $\overline{\text { MH801190 }}$ \\
\hline Sporidesmium fluminicola & MFLUCC 15-0346 & KU376271 & - & - & - \\
\hline Sporidesmium lageniforme & MFLU 18-1594 & MK849782 & МK828640 & MN194044 & MN124533 \\
\hline Sporidesmium lignicola & KUMCC 15-0266 & MK849784 & - & - & - \\
\hline Sporidesmium lignicola & DLUCC 1376 & MK849783 & - & MN194045 & - \\
\hline Sporidesmium melaleucae & CPC 32936 & MH327854 & МH327818 & - & - \\
\hline Sporidesmium melaleucae & CPC 32707 & МH327853 & МH327817 & - & \\
\hline Sporidesmium minigelatinosa & NN 47497 & DQ408567 & - & - & $\bar{D} Q 435090$ \\
\hline Sporidesmium parvum & HKUCC 10836 & DQ408558 & - & - & - \\
\hline Sporidesmium pyriformatum & MFLUCC 15-0627 & KX710143 & $\overline{\mathrm{K}} \mathrm{X} 710148$ & MF135663 & MF135650 \\
\hline Sporidesmium pyriformatum & MFLUCC 15-0620 & KX710141 & KX710146 & MF135662 & MF135649 \\
\hline Sporidesmium submersum & MFLUCC 15-0421 & KU376272 & - & - & - \\
\hline Sporidesmium thailandense & MFLUCC 15-0964 & MF374370 & - & MF370957 & MF370955 \\
\hline Sporidesmium thailandense & MFLUCC 15-0617 & MF077561 & - & MF135657 & - \\
\hline Sporidesmium tropicale & MFLU 17-0850 & MF077562 & MF077551 & - & - \\
\hline Sporidesmium tropicale & HKUCC 10838 & DQ408560 & - & - & - \\
\hline Sporoschisma hemipsilum & MFLUCC 17-1712 & MK835816 & MK828616 & MN194069 & MN156512 \\
\hline Stilbospora macrosperma & CBS 121883 & JX517299 & - & KF570235 & KF570196 \\
\hline Submersisphaeria aquatica & A354-1C & AY094194 & - & - & - \\
\hline Submersisphaeria aquatica & A95-1B & AY094193 & - & - & - \\
\hline Sydowiella centaureii & MFLU 16-2858 & KY523502 & - & - & - \\
\hline Thyridium vestitum & AFTOL-ID 172 & AY544671 & - & DQ471058 & DQ470890 \\
\hline Tubakia seoraksanensis & CBS 127490 & KP260499 & - & MG592094 & $\ldots$ \\
\hline
\end{tabular}


Supplementary Table 1 Continued.

\begin{tabular}{|c|c|c|c|c|c|}
\hline \multirow{2}{*}{ Taxon } & \multirow{2}{*}{ Voucher/Culture } & \multicolumn{4}{|c|}{ GenBank accession numbers } \\
\hline & & LSU & ITS & TEF & RPB2 \\
\hline Wongia aquatica & MFLUCC 18-1607 & MK849788 & MK828645 & MN194048 & MN124536 \\
\hline Wongia garrettii & DAR 79637 & - & KU850474 & KU850467 & - \\
\hline Wongia griffinii & DAR 80512 & KU850471 & KU850473 & - & - \\
\hline Wongia griffinii & BRIP 60377 & KU850470 & KU850472 & KU850466 & - \\
\hline Woswasia atropurpurea & WU32007 & JX233658 & NR154480 & - & JX233659 \\
\hline Xylaria hypoxylon & CBS 122620 & KY610495 & KY610407 & - & KY624231 \\
\hline Xylochrysis lucida & CBS 135996 & KF539911 & NR132063 & - & KF539913 \\
\hline Xylomelasma sordida & CBS 131683 & KM492871 & KT991679 & - & KM492910 \\
\hline Xylomelasma sordida & CBS 116000 & AY761087 & - & - & KY931929 \\
\hline Zalerion maritima & FCUL280207CP1 & JN886806 & KT347216 & - & - \\
\hline Zalerion xylestrix & 309156 & EU848592 & - & - & - \\
\hline
\end{tabular}

Ex-type strains are in bold; newly generated sequences are highlighted in red; new species are underlined. 